\title{
هواضع اختلاف الوقف والابتداء باختلاف قراءات القراء
}

$$
\text { د. دُّهيل مُحمَّد إقبال : }
$$

أستاذ الاراسات القر آنية بجامعة طيبة

كلية الآداب و العلوم الإنسانية بينبع 
مجلة كلية الدراسات الإسلامية والعربية للبنات بكفر الشيخ العددالثاني -المجلد السادس لعام 1/.مم

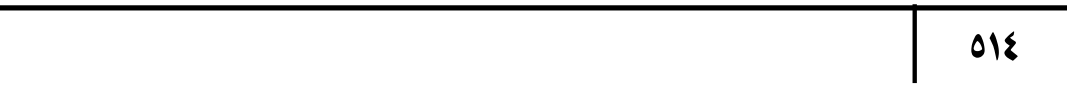




\section{ملخص البحث}

إن العلوم إنما تشرف بموضوعها، وتتفاضل بنوعها، فإن علوم

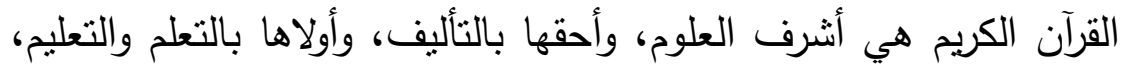
لأنها حول القرآن تدور ، وعلى حياضه تحوم، وفي نوره تسير . أهمية البحث وأسباب اختباره :

من العلوم المتعلقة بكتاب الله تعالى وقراءاته علم الوقف والابتداء، إذ به يتحقق فهم كلام الله تعالى ، حيث لا يدرك معناه إلا بذلك. فبين القراءات القرآنية والوقف والابتداء الصلة الكبيرة ، إذ باختلاف هله القراءات قد يتغبر حكم الوقف والابتداء؛ لأن الوقفَ والابتداءَ تابعُ للمعنى حسب القراءةِ المنلوََّة .

ومما قوى عزمي للاتجاه نحو هذا الموضوع الأسباب التالية : ـ ـ رغبتي في خدمة كتاب الله تعالى وعلومه . r- جمع ما يتعلق بهذا الموضوع في مكان واحد ، ليخرج بحثا

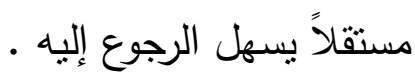
بـ ما تشهده الأمة الإسلامية اليوم من فتح جامعات وكليات ومراكز ومؤسسات لتعليم كتاب الله تعالى ، فالجدير بنا أن نساهم في دعم هذا المشروع تعليمًا وتأليفا. 
مجلة كلية الدراسات الإسلامية والعربية للبنات بكفر الشيخ العددالثاني-المجلد السادس لعام ^مبمم

\section{RESEARCH SUMMARY}

SCIENCE IS THE SUBJECT OF THE SCIENCES, BUT IT IS DISTINGUISHED BY ITS TYPE. THE SCIENCES OF THE HOLY QURAN ARE THE MOST HONORABLE SCIENCES, AND THEY ARE THE RIGHT TO WRITE, AND THE FIRST IS TO TEACH AND TEACH, BECAUSE IT REVOLVES AROUND THE QUR'AN.

THE IMPORTANCE OF RESEARCH AND THE REASONS FOR ITS SELECTION:

FROM THE SCIENCES RELATED TO THE BOOK OF ALLAAH AND ITS READINGS, THE KNOWLEDGE OF THE WAQF AND THE BEGINNING, IT IS ACHIEVED BY UNDERSTANDING THE WORDS OF GOD, WHERE HE DOES NOT REALIZE THE MEANING ONLY SO.

BetWeEn the QuRANIC READINGS AND THE WAQF AND THE BEGINNING OF THE GREAT LINK, AS THE READINGS MAY CHANGE THE RULE THE ENDOWMENT AND THE BEGINNING؛

AZMI'S DETERMINATION TO MOVE TOWARDS THIS SUBJECT HAS THE FOLLOWING REASONS:

1- My desiRe to SERVE THE BOOK OF AlLAH AND His ScIENCES.

2 - Gathering the subject in one place, to come UP With INDEPENDENT RESEARCH THAT IS EASY TO REFER TO.

3- WhAT THE ISLAMIC NATION IS WITNESSING TODAY FROM THE OPENING OF UNIVERSITIES, COLLEGES, CENTERS AND INSTITUTIONS TO TEACH THE BOOK OF GOD ALMightY, WE SHOULD CONTRIBUTE TO SUPPORT THIS PROJECT EDUCATION AND HEALING. 


\section{المقدمة}

الحمد لله ، والصلاة والسلام على رسول الله صلى الله عليه وسلم

$$
\text { وعلى آله وصحبه أجمعين ، وبعد : }
$$

فإن العلوم إنما تشرف بموضوعها، وتتفاضل بنوعها، فإن علوم القرآن الكريم هي أشرف العلوم، وأحقها بالتأليف، وأولاها بالتعلم والتعليم،

لأنها حول القرآن تدور ، وعلى حياضه تحوم، وفي نوره تسير .

$$
\text { أهمية البحث وأسباب اختياره : }
$$

من العلوم المتعلقة بكتاب الله تعالى وقراءاته علم الوقف والابتداء، إذ به يتحقق فهم كلام الله تعالى ، حيث لا يدرك معناه إلا بذلك. فبين القراءات القرآنية والوقف والابتذاء الصلة الكبيرة ، إذ باختلاف القراءات قد يتغير حكم الوقف والابتداء؛ لأن الوقفَ والابتداءَ تابعُ للمعنى حسب القراءةِ المنلزوََّة .

ومما قوى عزمي للاتجاه نحو هذا الموضوع الأسباب التالية : ـ ـ رغبتي في خدمة كتاب الله تعالى وعلومهه . r. جمع ما يتعلق بهذا الموضوع في مكان واحد ، ليخرج بحثا

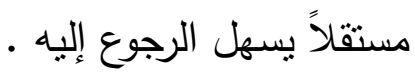
rـ ما تشهـه الأمة الإسلامية اليوم من فتح جامعات وكليات ومراكز ومؤسسات لتعليم كتاب الله تعالى ، فالجدير بنا أن نساهم في دعم هذا المشروع تعليمًا وتأليفا. 


\section{منهج البحث :}

تفصيل المواضع التي تغير فيها حكم الوقف والابتداء بسبب اختلاف

$$
\text { القراءات ، وسلكت النهج التالي : }
$$

ا ـ اخترت المواضع التي تغير فيها حكم الوقف والابتداء بسبب اختلاف

القراءات في القرآن الكربم ، وبلغت ما يقارب ( •.0 موضعاً .

r- التزمت في البحث القراءات العشر المتواترة ، ولم أتطرق للقراءات الثاذة .

\section{بـ أعتمد عند ذكري للقراعات العثر على :}

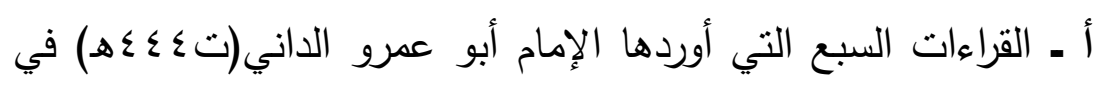

كتابه: (التيسير في القراءات السبع)، ومختصره نظم:( الشاطبية) المسمى بـ (حرز الأماني ووجه التهاني ) للإمام الثاطبي

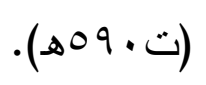

ب ـ القراءات الثلاث المكملة للعشر، التي أوردها الإمام ابن الجزري (ت سזم هـ) في كتابه: (تحبير التيسير في قراءات الأئمة العشرة)،

ونظمه: (الدرة المضية في القراءات الثناث المرضية) له أيضاً.

$$
\text { ع- ونهجت في هذا الفصل : }
$$

أولاً: ذكر الآية التي فيها خلاف بين القراء ولها الأثر على اختلاف

$$
\text { الوقف والابتداء. }
$$

ثانياً: أذكر القراءات الواردة في الآية، مع نسبتها لقرائها ـ

ثالثاً: أذكر توجيه القراءات الواردة في الآية، بالرجوع إلى كتب التفسير ومعاني القرآن وإعرابه، وكتب التوجيه.

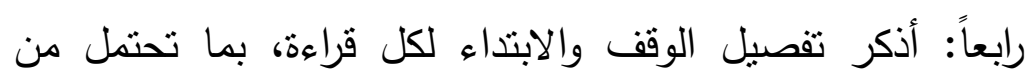

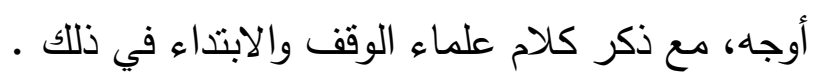




\section{وأراعي عند كتابتي للبحث الأمور التالية :}

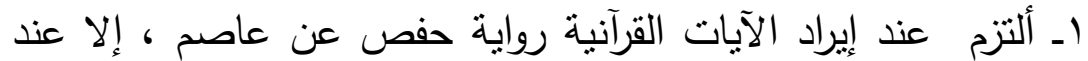

$$
\text { تفصيل القراءات فسأكتبها حسب القراءة . }
$$

r- عزو الآيات إلى مواضعها من المصحف الثريف ، مع ضبط الآية

بالثكل، وذكر رقم الآية، واسم السورة، حسب المثبت في المصحف التصات

المطبوع في(مجمع الملك فهذ لطباعة المصحف الثريف ).

بـ تخريج الأحاديث النبوية والآثار من المصادر المعتمدة .

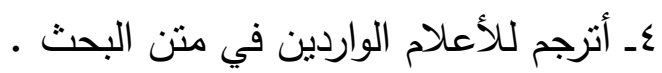

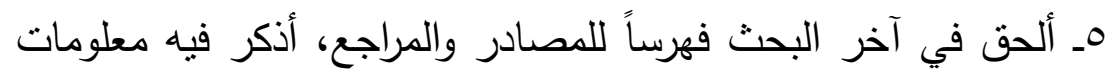

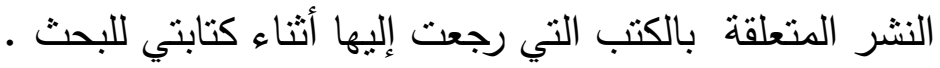

\section{خطة البحث:}

قمت بتقسيم هذا البحث إلى مقدمة، ومبحثين، وخاتمة :

المبحث الأول : علم الوقف والابتداء، وفيه أربعة مطالب : المطلب الأول : أهمية علم الوقف والابتداء.

المطلب الثاني : تعريف الوقف والابتداء.

المطلب الثالث : أقسام الوقف والابتداء .

المطلب الرابع :أثهر المؤلفات في علم الوقف والابتداء.

المبحث الثاني: تفصيل المواضع التي تغير فيها حكم الوقف والابتداء بسبب اختلاف القراءات،

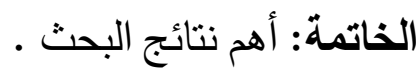

ملحق المصادر والمراجع • 


\section{المبحث الأول : علم الوقف والإتـاع}

\section{المطنب الأول:أهمبة علم الوقف والابتداء}

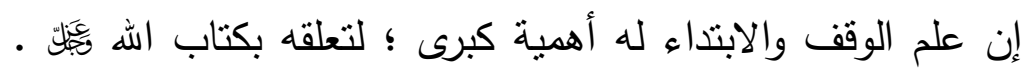
لذلك كان محل عناية رسول الله وقد علمهم النبي بـ عنهما:((لقد عشنا برهة من دهرنا، وإن أحدنا ليؤتى الإيمان قبل القرآن، وتتزل السورة على محمد : عنده منها، كما تتعلمون أنتم اليوم القرآن، ولقد رأينا اليوم رجالاً يؤتى أحدهم القرآن قبل الإيمان، فيقرأ ما بين فاتحته إلى خاتمته ما يدري ما

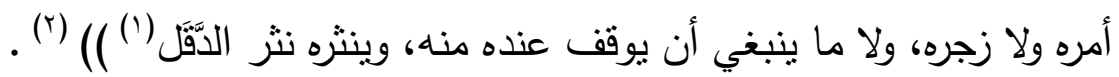
قال أبو جعفر النحاس عند ذكره لهذا الحديث:(( فهذا الحديث بيدل

على أنهم كانوا يتعلمون التمام كما يتعلمون القرآن)( (r) . وقال أيضاً: (( وقول ابن عمر : ( لقد عشنا برهة من دهرنا ) يدل

على ذلك إجماعُ من الصحابة)( (ء).

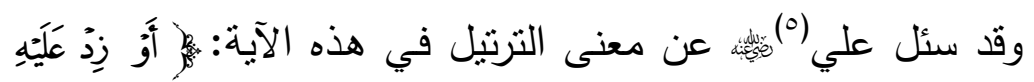

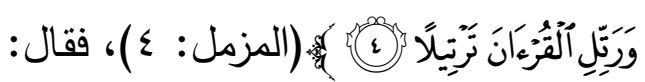

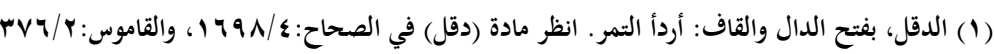

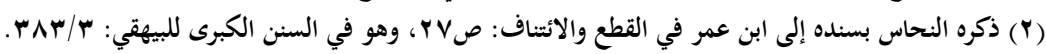

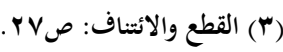

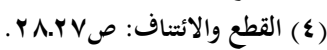

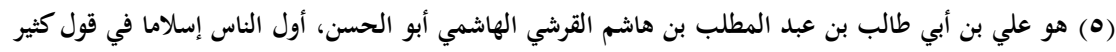

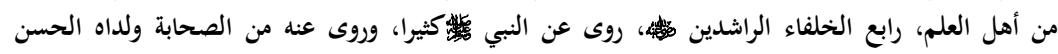

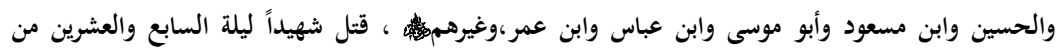

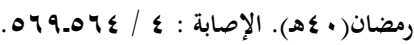




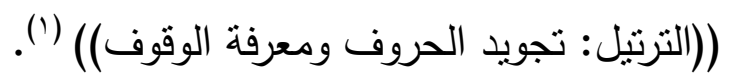

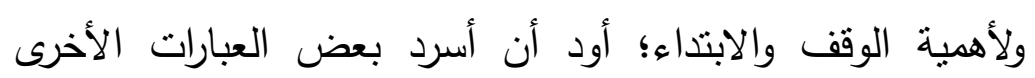
لعلماء هذا الفن، الدالة على أهميته وجلالته.

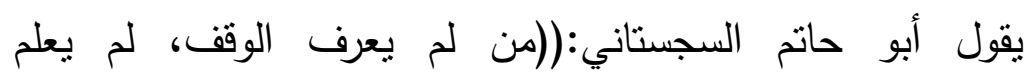
ما يقرأ() 


\section{المطلب الثاني: تعريف الوقف والابتداءع}

عند ذكرنا لأهمية الوقف والابتداء في كتاب الله عز وجل، يستحسن

$$
\text { بنا أن نذكر تعريف علماء }
$$

هذا الفن لهما. وقبل أن نذكر تعريفاتهم، نذكر أولاً تعريفات أهل

اللغة.

\section{تعريف الوقف والابتداء في اللغة:}

أولاً: تعربف الوقف لغة: الوقف في لسان اللغة، بطلق ويراد به

معان كثيرة، منها:

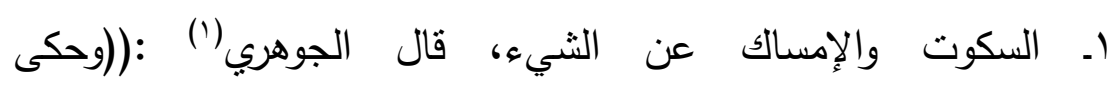
أبو عمرو(؟):كلمتهم ثم أوققت، أي: أسكت. وكل شيءٍ تمسك عنه

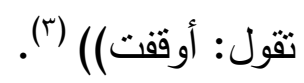

r. الحبس، يقال: ((وقفت الدار للمساكين وقفاً))،أي: حبستها، ((ووققت

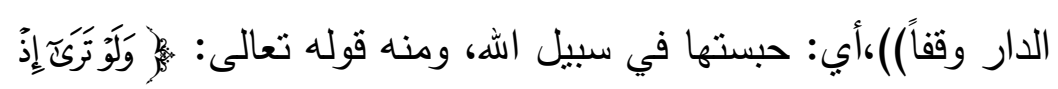

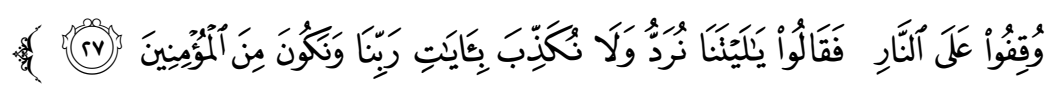

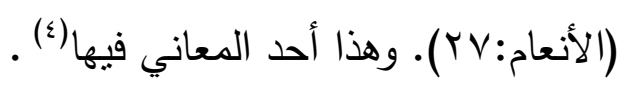

ء،بـ القيام ، والسكون ،قال الفيومي: (الدابة تقف وقفاً، وروقوفاً:

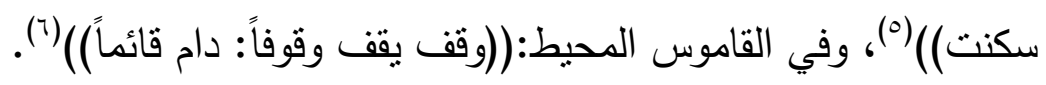

(1) هو أبو نصر إسماعيل بن حماد الجوهري الفارابي اللغوي،صاحب" الصحاح" في اللغة، كان إماماً في اللغة

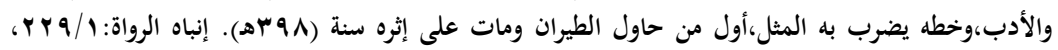

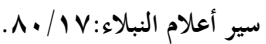

$$
\begin{aligned}
& \text { (r) أبو عمرو بن العلاء المقرئ. }
\end{aligned}
$$

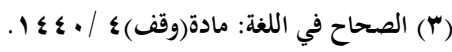

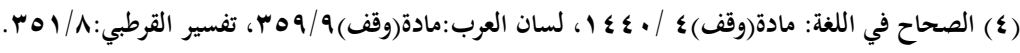

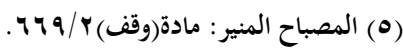

$111 \% / 1(7)$ 
هـ المنع، قال الفيومي:((وققت الرجلَ عن الثيء وقفاً، منعته عنه)( ('). V، 7. ويأتي الوقف أيضاً بمعنى المعاينة، وبمعنى الاخول، ومنه قوله

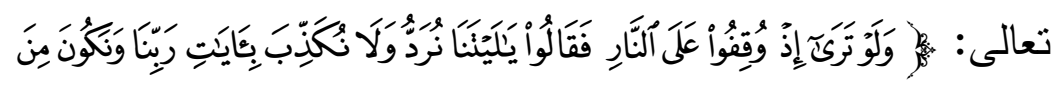
ألمُؤْينينينَ

ثثلاثة: المعاينة والاخول والحبس (r). ثانياً: تعريف الابتداء لغة: تلانه: الابتداء: من الفعل بدأ، والباء والدال والهمزة من: افتتاح الثيء، يقال:(بدأت بالأمر وابتدأت: من الابتداء. وبدأت بالثيء: فعلته

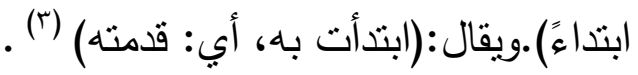

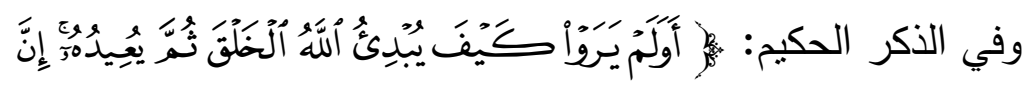

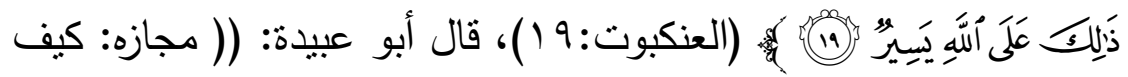

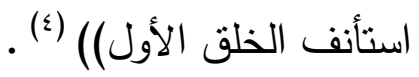
وفي الذكر الحكيم أيضاً: قال القرطبي في تفسيره: ((يعني الخلق . عند أكثر العلماء . يخلقهم

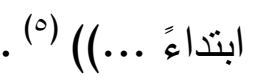

\footnotetext{
(1) (Y)

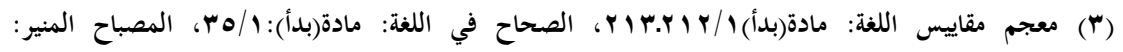

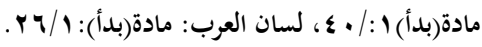

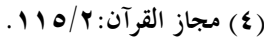

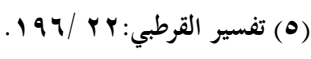


تعريف الوقف والابتاء في الاصطلاح: أولاً: تعريف الوقف اصطلاحاً:

أنشهر وأجمع تعريف له هو تعريف الإمام الهام ابن الجزري، حيث

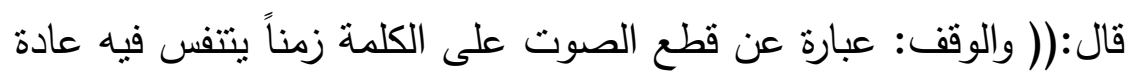

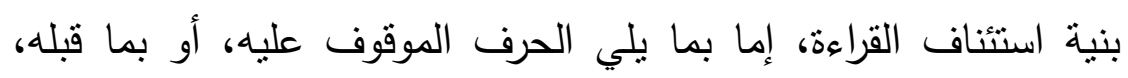

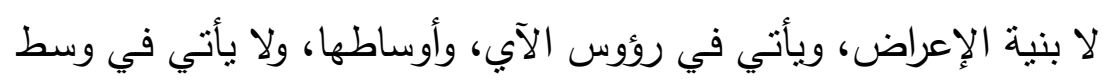

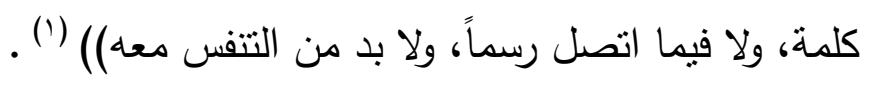

الفرق بين الوقت والقطع والسكت:

فال ابن الجزري:((هذه العبارات جرت عند كثير من المتقدمين مراداً

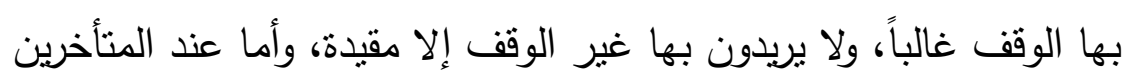
وغيرهم من المحققين فإن: القطع عندهم: عبارة عن قطع القراءة رأساً، فهو كالانتهاء، فالقارئ

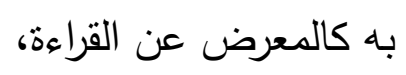

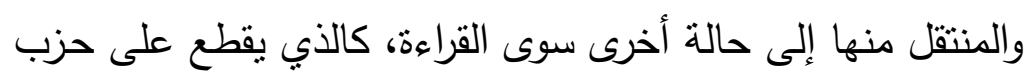

$$
\text { أو ورد أو عشر ، أو في منها الى }
$$

ركعة ثم يركع، ونحو ذلك مما يؤذن بانقضاء القراءة والانتقال منها

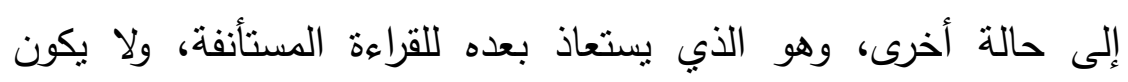

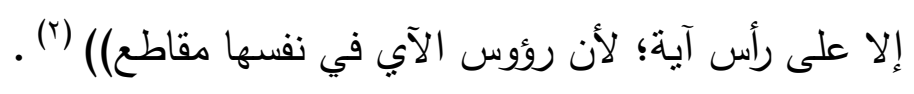
ثم عرف الوقف كما ذكرناه عنه سابقاً. ثم قال: (( والسكت: هو عبارة عن قطع الصوت زمناً هو دون زمن عناه الوقق عادة من غير تتفس. 
وقد اختلفت ألفاظ أئمتتا في التأدية عنه، بما يدل على طول السكت

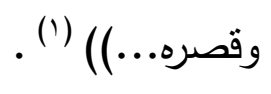

ثانياً: تعريف الابتداء اصطلاحاً:

لم أقف على تعريف الابتداء في اصطلاح المتقدمين والمتأخرين في هذا الفن، غير تعربف الإمام الصفاقسي(r) ، حيث قال:( والابتداء: هو

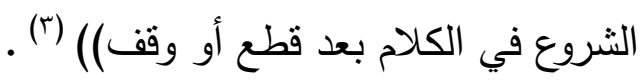

أما البقية فإنهم كانوا يقتصرون على تعريف الوقف، ولم يعرفوا الابتداء بتعريف خاص، ولعل السبب في ذلك: أنه بتعريف الوقف يتضح تعريف الابتداء؛ لأن الابتداء ناشئ عنه.

فتعريف ابن الجزري للوقف ، يمكن أن يستخلص منه تعريف

الابتداء ، فنقول: ( هو استثناف القراءة بعد قطع الصوت المتتفس فيه زمناً ما).

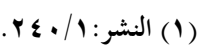

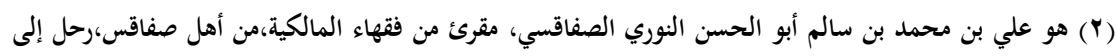

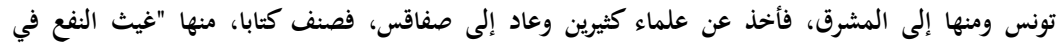

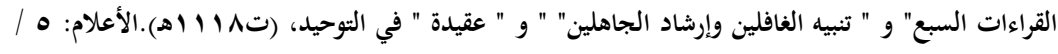

(ץ) تنبيه الغافلين وإرشاد الجاهلين: صצr. 


\section{المطلب الثالث : أقسام الوقف والابتداء :}

إن علماء هذا الفن قد اختلفوا في أقسامه ، والاختلاف كائن في

العدد والمسمى، ثم إن هذه المسميات له ، كما سنذكرها ــ إن شاء الله -

قد تتقق في اللفظ المسمى والمعنى - أي: المراد من اللفظ المسمى معاً، وقد تتفق في اللفظ المسمى وتختلف في المعنى ، والعكس ، أي : قد تختلف في اللفظ المسمى وتتفق في المعنى ، وأيضاً قد تختلف في اللفظ المسمى والمعنى معاً.

وهذا الاختلاف في الأقسام ، يعود إلى اصطلاح الإمام في هذا

$$
\text { الفن من حيث العدد والمسمى. }
$$

يقول الأشموني : (( والناس في اصطلاح مراتبه مختلفون ، كل

$$
\text { واحدٍ له اصطلاح على ما شاء ، }
$$

كما وهذه التقبيمات التي سنوردها نرتبها من الأقل عدداً إلى

$$
\text { الأكثر - ترتيباً تصاعدياً - فنقول : }
$$

أ ـ فمنهم من قسم الوقف والابتداء إلى قسمين:

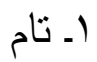

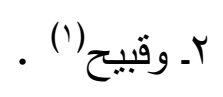

ب - ومنهم من قسمه إلى ثلاثة أقسام ، على اختلاف بينهم في

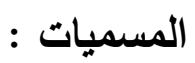

ـ قبعضهم قال : 


$$
\text { r- }
$$

ب- وقبيح • وهذا التقسيم لابن الأنباري(').

- ويعضهم قال :

$$
\begin{aligned}
& \text { 1- تام } \\
& \text { r- وكاف } \\
& \text { ب-وقبيح(ץ). } \\
& \text { ويعضهم قال : } \\
& \text { 1- تام } \\
& \text { r- وناقص } \\
& \text { - }
\end{aligned}
$$

إلا أنه قسم هذه الثثلاثة إلى خمسة أقسام فقال :

$$
\text { rـ الأتم }
$$

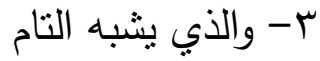

ع - - والناقص المطلق

0- والأنقص (r).

صرح بذلك صدر الثريعة ، وناهيك به )) (ء).

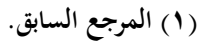

$$
\begin{aligned}
& \text { (r) (ب) منار الهدى: }
\end{aligned}
$$

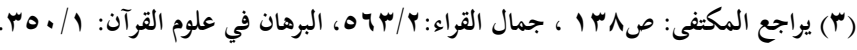

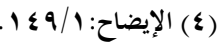


ج - ومنهم من قسمه إلى أربعه أقسام :

$$
\text { r }
$$

ع- وقبيح • وهذا التقسيم عند الداني والسخاوي وابن الجزري(1). ونسب الداني هذا التقسيم الأخير إلى بعضهم ، ورجحها ، وقال:

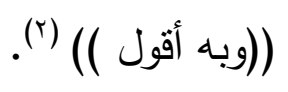

دـ - واختار أبو الحسن الصفا قسي تقسيم الداني ، إلا أنه قسم كل قسم إلى قسمين ، أي: فجعله ثمانية أقسام :

$$
\begin{aligned}
& \text { 1- نام } \\
& \text { r } \\
& \text { r- وكاف } \\
& \text { ع - وأكفى } \\
& 0 \\
& \text { 7- وأحسن } \\
& \text { V- وقبيح } \\
& \text { - } 1 \text { وأقبح (r). }
\end{aligned}
$$

هـ - منهم من قسمه إلى خمسة أقسام :

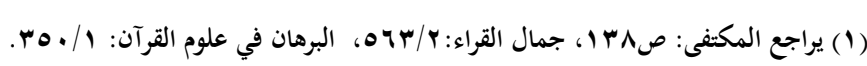

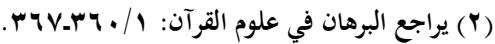

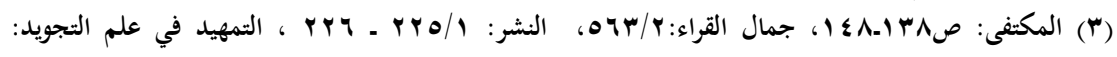

$$
\begin{aligned}
& \text { ص } 170
\end{aligned}
$$




$$
\begin{aligned}
& \text { ا } \\
& \text { r- وكاف } \\
& \text { " - وحسن } \\
& \text { ع- وقبيح }
\end{aligned}
$$

ه- ومترد بين هذه الأقسام فتارة بتصل بالتام، وتارة بالقبيح ، على

$$
\text { حسب اختلافهما قراءة وإعراباً وتفسيراً . }
$$

و - وهذا التقسيم عند الأثموني ، إلا أنه جعله عشرة مراتب :

$$
\begin{aligned}
& \text { ا } \\
& \text { r- وأتم } \\
& \text { r- وكاف } \\
& \text { ع - وأكفى } \\
& 0 \text { - وحسن } \\
& \text { 7- وأحسن } \\
& \text { V- وصسالح }
\end{aligned}
$$

^- وأصلح ، وبعبر عنه بالجائز

$$
\text { 9- وقبيح }
$$

ز - ومنهم من قسمه إلى ستة أقسام ، على اختلاف بينهم في

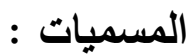

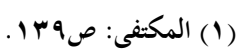




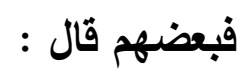

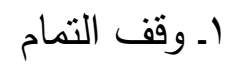

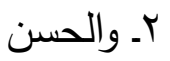

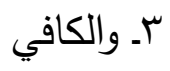

ع. والسنة

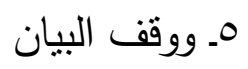

Tـ ووقف التمييز • وهذا التقسيم عند أبي القاسم الهذلي (').

وبعضهم قال :

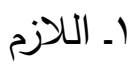

r. بـ والمطلق

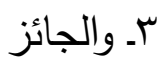

عـ والمجوز لوجه

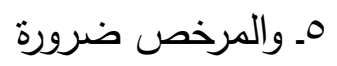

Tـ وما لا يجوز الوقف - أو ما لا وقف عليه .

وهذا التقيم عند أبي عبد الله السجاوندي ، ويرمز لهذه الأقسام

الستة بعلامات : فيرمز للازم بحرف (م) ، وللمطلق بحرف (ط) ، وللجائز بحرف (ج) ، والمجوز لوجه بحرف (ز)، والمرخص لضرورة

بحرف (ص) ، ومالا وقف عليه بعلامة (لا ) (؟). 
إلا أنه ينبغي التتبيه إلى أن السيوطي والأشموني ، والمحقق(') لكتاب (علل الوقوف ) للسجاوندي، ذكروا: أن الأفسام أو المراتب عند

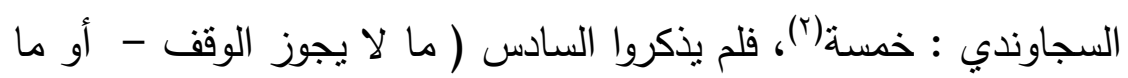
لا وقف عليه ).

ولكن الذي يتضح من كتاب (علل الوقوف)،للسجاوندي، أن الوقف

عنده ستة أقسام ، وأن السادس قد ذكره للأمور الآتية : اـ أنه قد صرح به عند تقسيماته للوقف. r- r. وجعل له ضوابط . "ـ وجعل له علامة ( لا ). عـ وطبقه على مواضع القرآن (r) ('). ح - ومنهم من قسمه إلى ثمانية أقسام ،على اختلاف بينهم في المسميات:

فبعضه قال : الوقف في التنزيل على ثمانية أضرب :

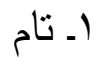

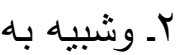

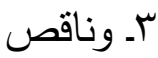
عـ وشبيه به 0ـ وحسن Tـ وشبيه به V - V وقبيح

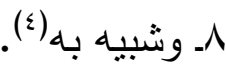

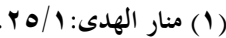

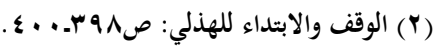

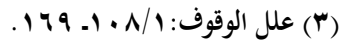
(ع) وهو الدكتور / محمد بن عبد الله بن محمد العيدي. 


$$
\begin{aligned}
& \text { ويعضهم قال : الوقف على مراتب : } \\
& \text { ا ــ أعلاها التام } \\
& \text { r. بـ تُم الحسن }
\end{aligned}
$$

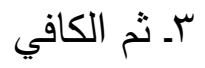

$$
\begin{aligned}
& \text { عـ ثم الصالح } \\
& \text { هـ ثم المفهوم }
\end{aligned}
$$

فأقسامه ثمانية ـ وهذه المراتب عند أبي يحيى زكريا الأنصاري(').

$$
\begin{aligned}
& \text { ويعضهم قسمه إلى: } \\
& \text { 1. كاملاً } \\
& \text { r. تاماً } \\
& \text { بـ كافياً } \\
& \text { ع. صالحاً } \\
& \text { هـ مفهوماً } \\
& \text { 7. جائزاً }
\end{aligned}
$$

ط - وقسمها الثيخ حكيم زادة إلى أحد عشر قسماً ، وجعل لكل قسم من الأقسام رمزاً يعرف به واستفاد ذلك من تقسيمات السجاوندي ورموزه وتطبيقاته للرموز في مواضع القرآن، وأضاف إلى ذلك بلك أقسام ورموز أخرى ، ونظمها في منظومته:(مبادئ معرفة الوقوف) 


\section{المطلب الرابيع :أشهـه المؤلفات في علم الوقف والابتـاع}

ذكرنا سابقاً أهمية الوقف والابتداء، ونظراً لذلك رأينا أن نذكر اهتمام

علماء هذا الفن في تأليفهم لهذا العلم، فنذكر أثهر المؤلفات، وأثنير إلى أن الباحثين والمحققين(') قد سبقوني إلى ذكر المؤلفات في هذا العلم ، فذكروا أكثر من : (تمانين) مصنفاً مفرداً في هذا الفن ، منها: المفقودة ، ومنها: المخطوطة، ومنها: المطبوعة.

من أجل ذلك رأيت أن أقتصر على ذكر الكتب المطبوعة في هذا الفن (ץ) ، مرتباً لها حسب ناريخ وفيات أصحابها، ومستفيداً مما ذكره الأخوة المحققون. ا. كتاب: (الوقف والابتداء في كتاب الله عز وجل) (ז) ،لأبي جعفر محمد (كد بن سعدان الضرير الكوفي (๕) (ت ابr هـ). r. كتاب: (إيضاح الوقف والابتداء في كتاب الله عز وجل)، لأبي بكر

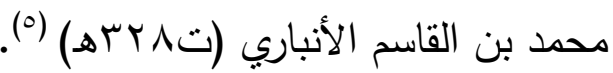
r. كتاب: (القطع والائتاف)، لأبي جعفر أحمد بن محمد النحاس

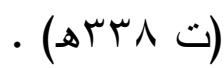

(1)مثل: الدكتور المرعلشي في مقدمة تحقيقه لكتاب:(المكتفى في الوقف والابتداء)، للداني، و الدكتور العيدي في

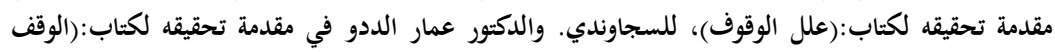
والابتداء) للهذلي (Y)وما كان من هذه الكتب قد اتخذها الباحث مراجع له في بحثله: لم يشر فيها إلى أسماء محققيها، ومكان الطبع،

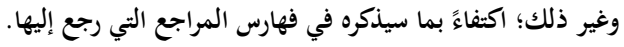

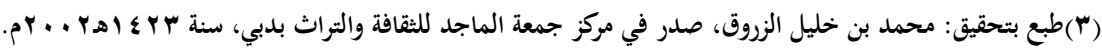

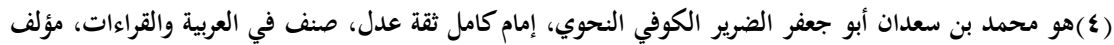

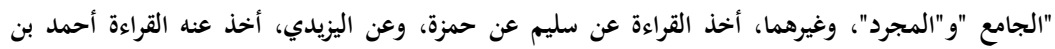

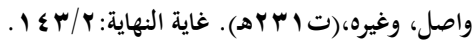

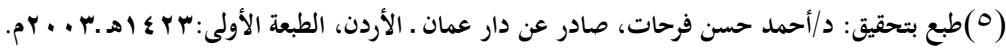


ع. كتاب: (شرح كلا وبلى ونعم والوقف على كل واحدة منهن في كتاب اله عز وجل) (')، لأبي محمد مكي وني والب أبي طالب القيسي

$$
\text { (ه }) \text { (ت }
$$

ه. كتاب: (المكتفى في الوقف والابتداء)، لأبي عمرو عثمان بن سعيد

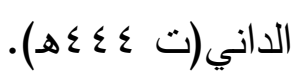

7. كتاب: (الوقف والابتداء)، لأبي القاسم يوسف بن علي الهذلي

$$
\text { . }
$$

V. كتاب: (الوقف والابتداء) (r)، لأبي الحسن علي بن أحمد الغزال(r)

$$
\text { . }
$$

^ـ كتاب: (علل الوقوف)، لأبي عبد اله محمد بن طيفور السجاوندي(؟)

$$
\text { . (ت . (ن) }
$$

9. كتاب: (نظام الأداء في الوقف والابتداء) (0)، لابن الطحان،عبد العزيز

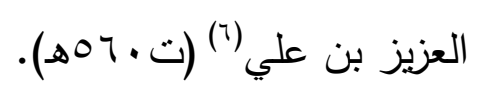

(1) طبع من أوله إلى نهاية سورة الكهف، بتحقيق عبد الكريم العثمان، رسالة دكتوراه، في الجامعة الإسلامية،

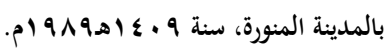

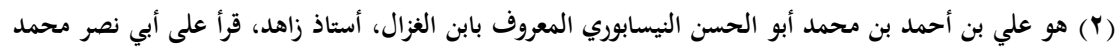

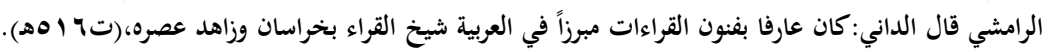

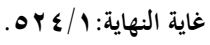

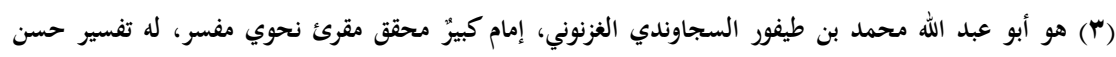

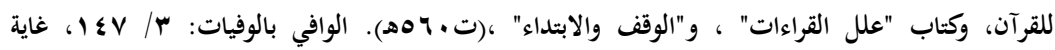

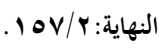

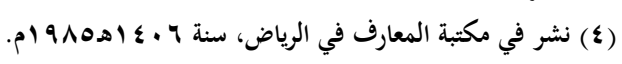

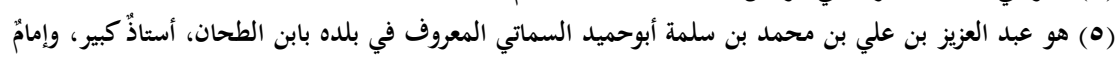

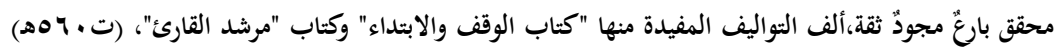

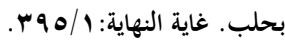

(آ) طبع بتحقيق مسعود أحمد إلياس، رسالة دكتوراه، في الجامعة الإسلامية، بالمدينة المنورة، سنة

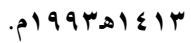


• ا. كتاب: (الاقتداء في معرفة الوقف والابتداء) (')، لعبد اله بن محمد

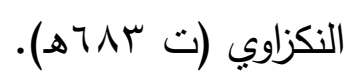

1 اـ كتاب: (المقصد لتلخيص ما في المرشد في الوقف والابتداء)، لأبي

$$
\text { يحيى زكريا بن محمد الأنصاري (ت جr } 9 \text { هـ). }
$$

r ا. كتاب: (القول الفصل في اختلاف السبعة في الوقف والوصل)

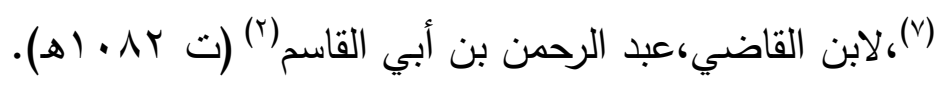

با. كتاب: (منار الهدى في بيان الوقف والابتدا)، لأحمد بن محمد بن

عبد الكريم الأشموني (ץ)(من علماء القرن الحادي عشر الهجري).

ع ا. كتاب:(مبادئ معرفة الوقوف)، وهو نظم (بعبيتاً)، لمحمد بن عبد اهن

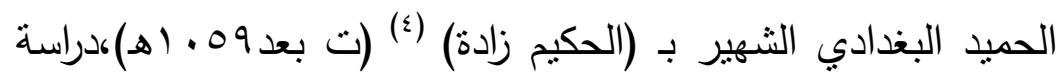

وتحقيق وشرح: د/ محمد بن إبراهيم المشهداني (ن). 1. كتاب:(معالم الاهتداء إلى معرفة الوقوف والابتداء)، لمحمود بن

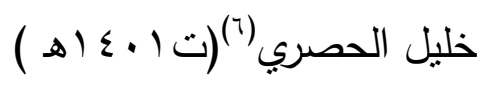

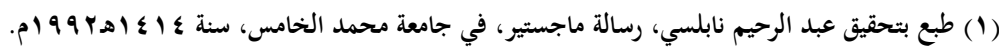

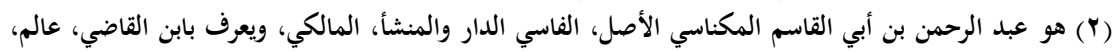

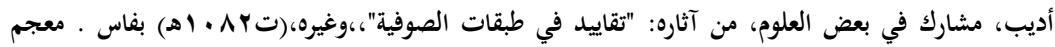

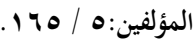

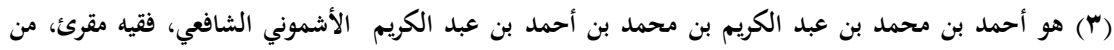

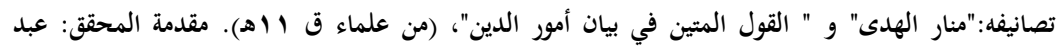

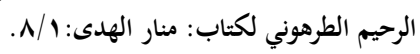

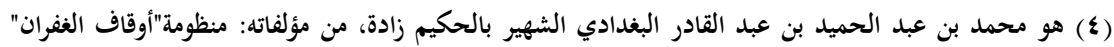

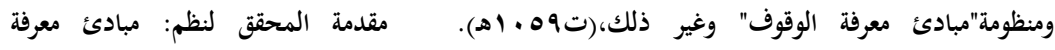

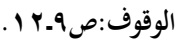
(•) هو د/ محمد بن إبراهيم بن فاضل المشهداني، أستاذ التفسير وعلوم القرآن المساعد ـ كلية الدراسات الإسلامية

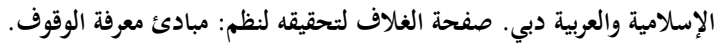

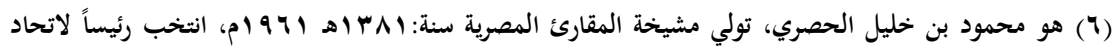

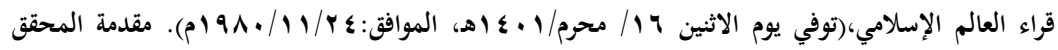

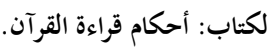


وهناك مؤلفات في علوم القرآن والقراءات، ولكنها أدرجت هذا العلم

فيها، فمن أشهرها:

ا. كتاب:(جمال القراء وكمال الإقراء)، لعلم الدين علي بن محمد

$$
\text { السخاوي (ت بـ Tهـ). }
$$

r. كتاب:(البرهان في علوم القرآن)، لبدر الدين محمد بن عبد الله

$$
\text { الزركثي (ت ع ع هـ). }
$$

r. كتاب:(النشر في القراءات العشر)، للحافظ أبي الخير محمد بن

$$
\text { محمد الجزري (ت سبهـ). }
$$

ع. كتاب:(الإتقان في علوم القرآن)، لأبي الفضل جلال الدين عبد

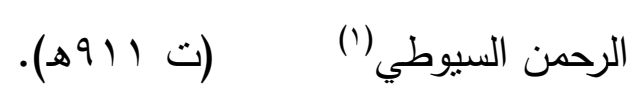

ه. كتاب:(لطائف الإشارات لفنون القراءات)، لشهاب الدين أحمد بن

$$
\text { محمد القسطلاني (ت }
$$

7. كتاب:(أحكام قراءة القرآن الكريم)، لمحمود بن خليل الحصري

$$
\text { (ه) (ت ( ) }
$$

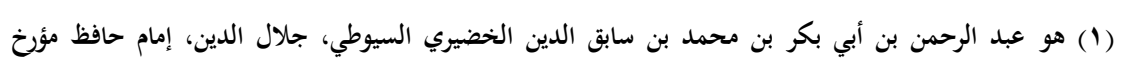

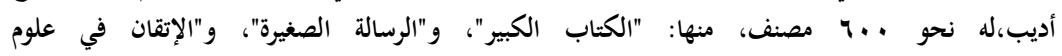

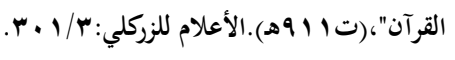


المبحث الثاني:

تفصيل المواضع التي تغير فيها حكم الوقف والابتداء بسبب اختلاف

قراعات القراء

$$
\text { الموضع الأول }
$$

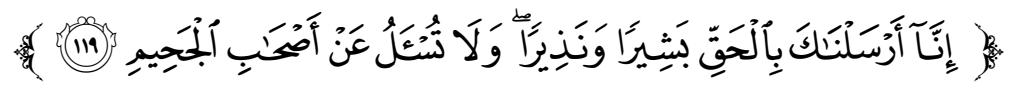

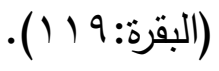

\section{القراعات:}

اـ قرأ نافع، ويعقوب : جِبج شتْيَّلْ جه بفتح التاء وجزم اللام.

r. وقرأ الباقون: جهبج بح جـ بضم التاء وضم اللام (').

على قراءة الجزم بأوجها الثلاثة يكون الوقف على قولهجئى

$$
\text { كافٍ؛ لأن الجملة بعده على }
$$

النهي، وما قبله على الخبر، فكأنه أولاً أخبر بجملة خبرية، ثم

استأنف بجملة على النهي.

والوقف حسنٌ وليس بتام عند ابن الأنباري، وكافٍ عند الداني،

وليس بتمام عند النحاس. ذكروا

ذلك على الوجه الأول من قراءة الجزم. وحسنٌ عند الأشموني على الوجهين الأولين.

وبعضهم أطلق على قراءة الجزم على النهي، ولم يبين على أي 
فذكر ابن غلبون جواز الابتداء؛ لأنه استئناف نهي. وذكر السجاوندي له أن يقف؛ لاختلاف الجملتين. وجعله الأنصاري وقفاً حسناً.

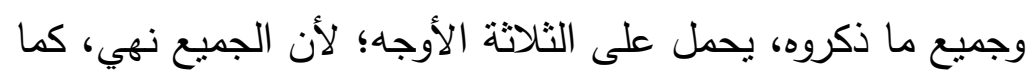

$$
\text { سبق في التوجيه. والله تعالى أعلم. }
$$

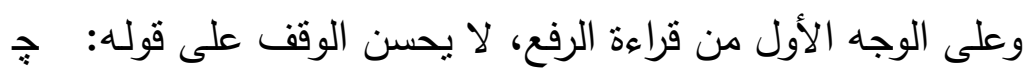

$$
\text { ئىج ، ولا الابتداء بما وعلى الاجه }
$$

بعده؛ لتعلق ما بعده بما قبله، وذللك أن ما بعده هو في موضع

الحال، عطفاً على ما قبله.

وقريباً من هذا، ذكره ابن غلبون والداني ، ورمز له السجاوندي

بعلامة الوقف الممنوع (لا).

وقال الأنصاري: الوقف جائز .

وعلى الوجه الثاني من قراءة الرفع، يكون الوقف على قوله:جئىج

كافٍ؛ لأن ما بعده جملة

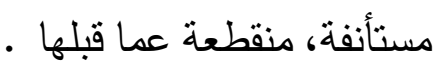

والوقف كافٍ عند الداني والأشموني، وحسن عند ابن الأنباري

والأنصاري؛ إلا أنه عند ابن الأنباري أحسن مما هو على والثي وجه النهي (1).

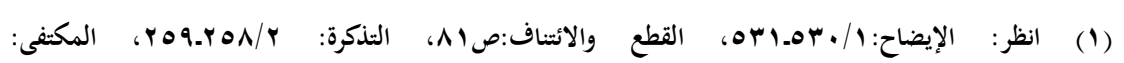

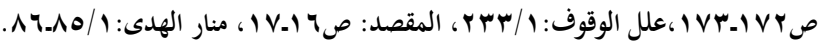




\section{الموضع الثاني}

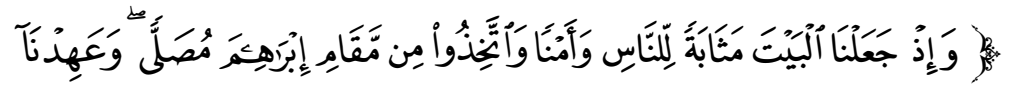

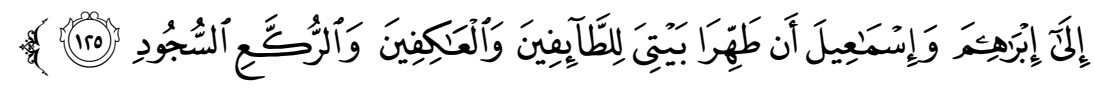

(البقرة: مبال).

القراعات:

اـ قرأ نافع، وابن عامر : جـ وَاتْنَذَذُواً جِبفتح الخاء على لفظ الخبر.

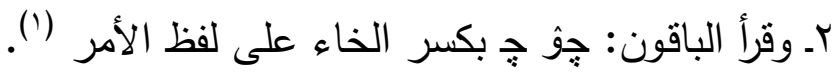

على الوجهين الأولين من قراءة الخبر يكون الوقف على قوله

تعالى: جورج حسناً وليس بتام ولا كاف ؛ لأن ما بعده عطف على ما لأنى

قبله، إلا أن الوقف على الوجه الثاني أحسن مما هو على الوجه الأول؛ لأنهما جملتان، بينما الوجه الأول جملة واحدة.

وقال ابن الأنباري على الوجه الأول منهما: لم يكن وقفه على جهو

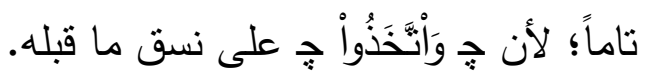

وقال الأشموني على الوجه الثاني منهما: لا يقف على جه و

لأنه عطفٌ على ما قبله.

كما سبق في التوجيه.

وبعضهم أطلق على قراءة الخبر ، ولم يبين على أي وجه:

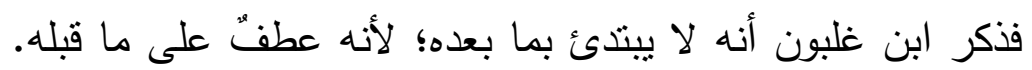

وذكر الداني أنه لا يقف عليه؛ لأن ما بعده عطفُ على ما قبله. وقال

الأنصاري: الوقف جائز . 
ولعل عبارتهم لا تخرج عن أحد الوجهين الأولين من قراءة الخبر.

والله تعالى أعلم.

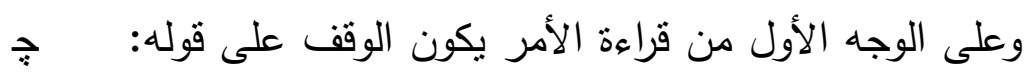

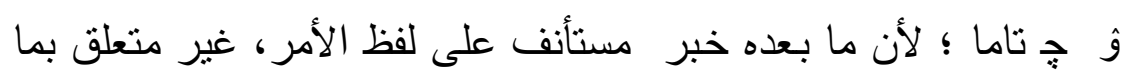
قبله، ويؤيده سبب النزول، كما أوردناه.

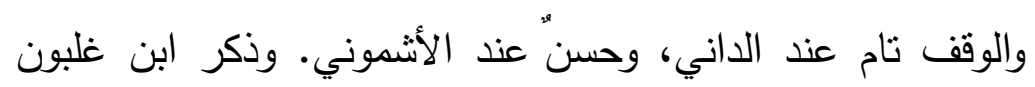

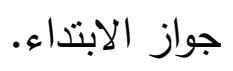

وبعضهم أطلق على قراءة الأمر، ولم يبين على أي وجه:

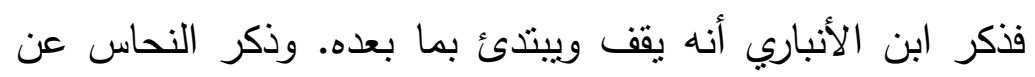
الأخفش أنه وقف تمام. وجعله السجاوندي وقفاً مطلقاً، والأنصاري وقفاً حسناً (1).

ومن أطلق ذللك، فلعله يقصد على الوجه الأول. والله تعالى أعلم.

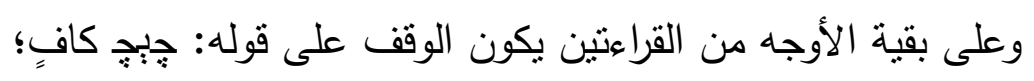

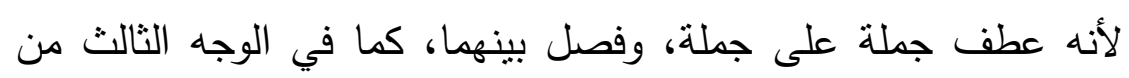
القراءتين. ومعمول لقول محذوف، كما في الوجه الثاني من قراءة الأمر. وعطف على محذوف، كما في الوجهين الأخيرين من القراءتين.

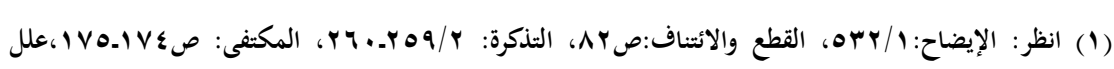

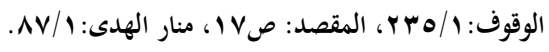




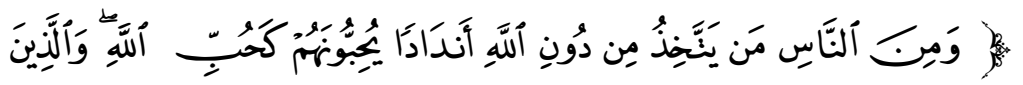

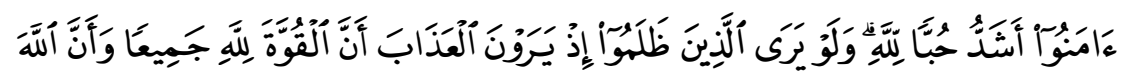

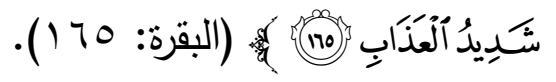

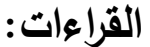

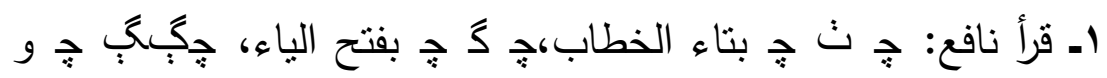

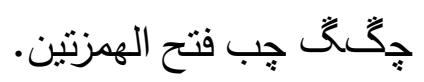

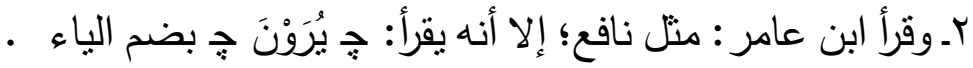

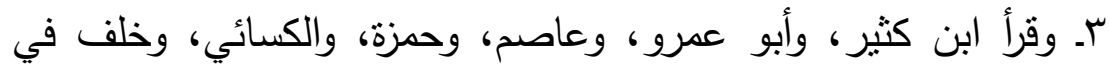
انفراده: متل نافع؛ إلا أنهم قرعوا: جك جه بياء الغيب.

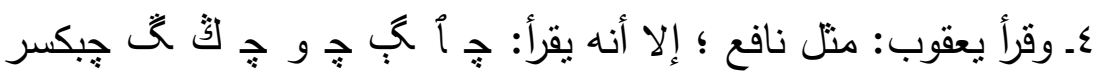

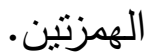

هـ وقرأ أبو جعفر : منل يعقوب ؛ إلا أنه يقرأ: جك جه بياء الغيب ('). قد تكلم بعض علماء هذا الفن على ما يوقف في هذه الآية

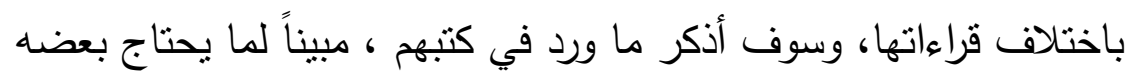

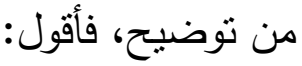

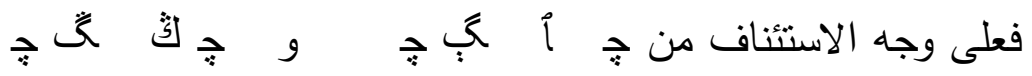
في قراءة أبي جعفر ويعقوب: ذكر ابن الأنباري والداني: أن الوقف على اله

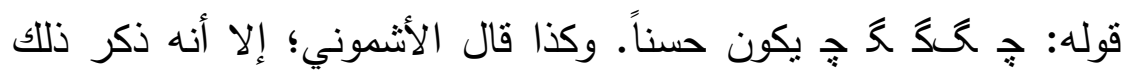

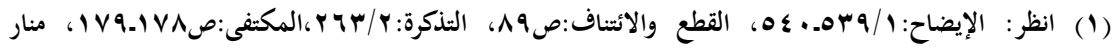


على قراءة التاء ـ أي قراءة يعقوب ـ، ولم يتعرض للقراءة الأخرى. وعلى وجهي قراءة ابن كثير ومن معه: ذكر النحاس والداني

$$
\text { والأشموني: أنه لا يقف على قوله: }
$$

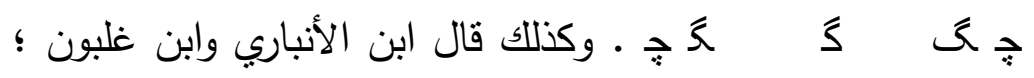

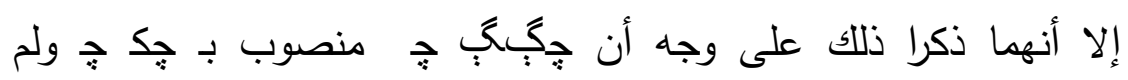
يتعرضا للوجه الآخر •

وعلى الوجه الرابع من قراءة نافع وابن عامر ، على تقدير الفراء،

وهو أنه قدره على تكرير : ( يرون ) : ذكر النحاس والداني وابن

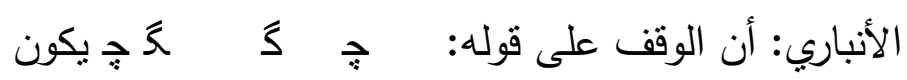

$$
\text { حسناً؛ إلا أن ابن الأنباري، قدر تكرير :( ترى ). }
$$

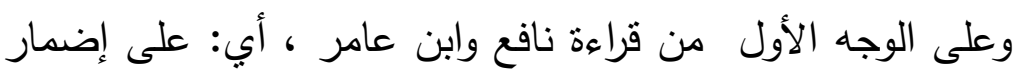

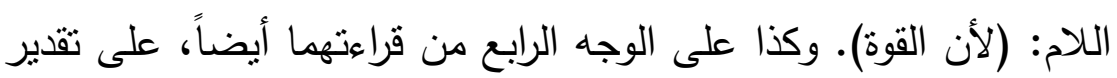
الطبري، وهو أنه قدر فعل: (لرأيت): ذكر النحاس أنه لا يوقف على قولى لهنه

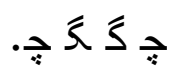

ولعلهم يقصدون بالوقف الحسن الذي ذكروه في قراءة أبي جعفر

ويعقوب، الوقف الكافي : الذي يحسن الوقف عليه والابتداء بما بعده.

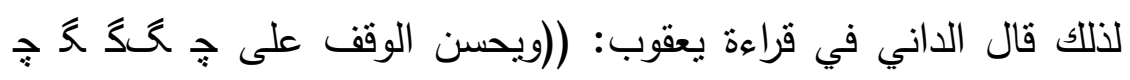
ويكفي)). وقال ابن الأنباري في قراءة أبي جعفر :((كان الوقف على: جـ

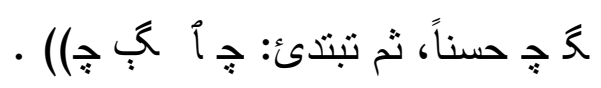

وأما الوقف والابتداء على بقية الأوجه، بمختلف القراءات، التي لم لم

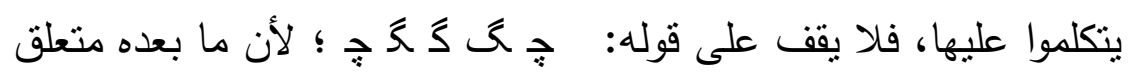

$$
\text { بمحذوف الذي هو جواب (لو). }
$$




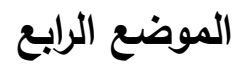

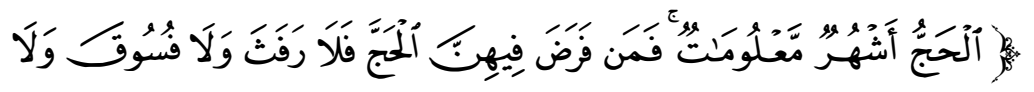

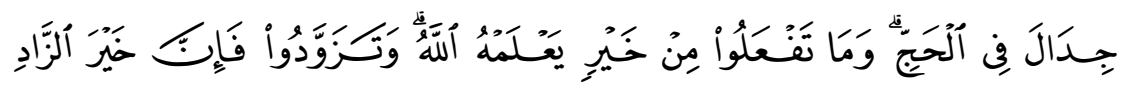

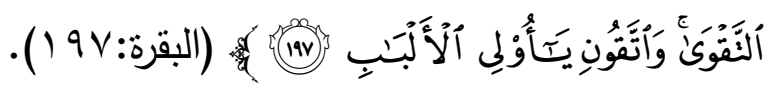

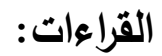

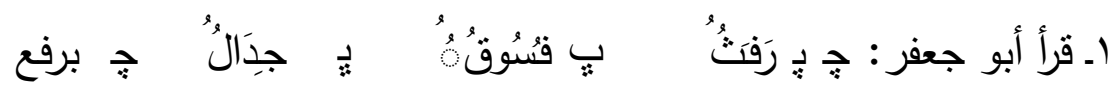

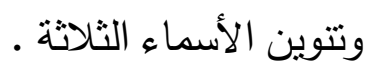

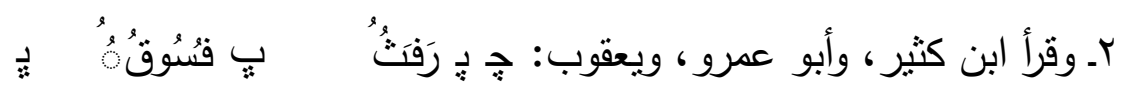

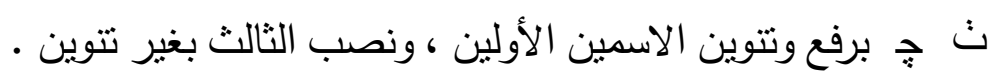

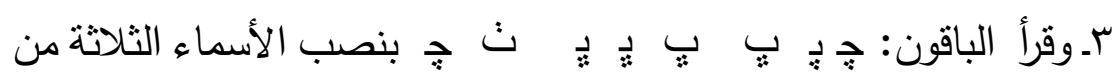
غير نتوين (')

على قراءة رفع الاسمين الأولين ونصب الثالث: يكون الوقف على

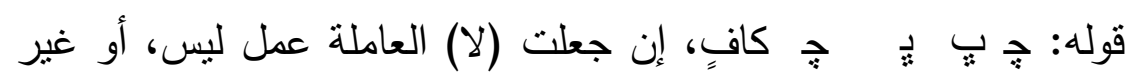

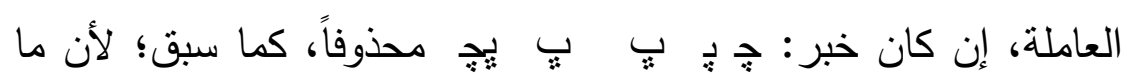

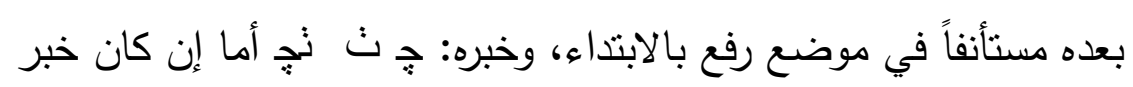

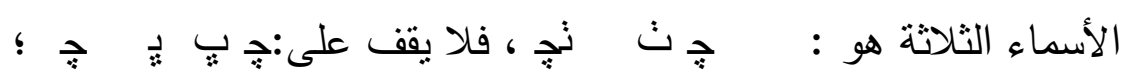
لئلا يفصل بين الاسم وخبره.

والوقف كافٍ عند الداني والأثموني ، على أن (لا) عاملة عمل

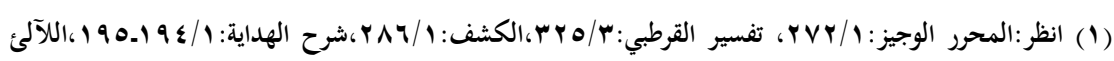


وقال الأنصاري: وقف كافٍ، ولم يبين على أي وجه.

وعلى قراءة رفع الأسماء الثلاثة، وكذلك على قراءة نصب الأسماء

الثلاثة، لا يقف على قوله:

ج ":

بالعطف عليهما، وأيضاً لئلا يفصل بين الاسم وخبره، أو بين المبتدأ

وخبره.

وقربياً من هذا ذكره ابن الأنباري وابن غلبون والداني والأشموني؛

إلا أن غير ابن غلبون لم يتعرضوا لقراءة رفع الأسماء الثناثة('). 


\section{الموضع الخامس}

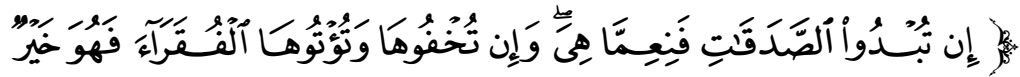

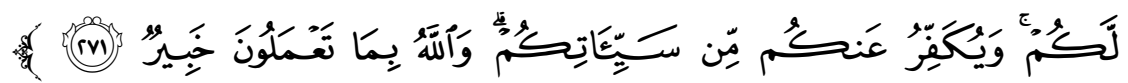

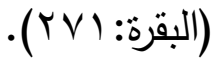

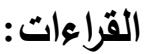

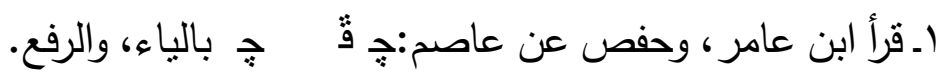

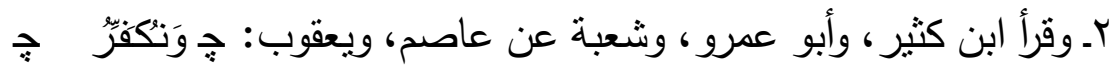

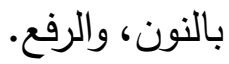

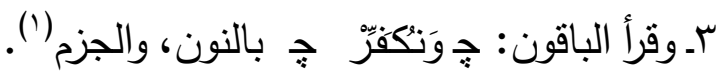

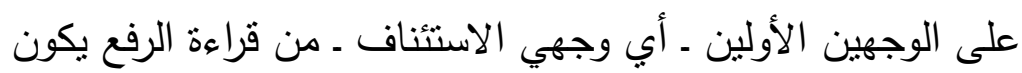

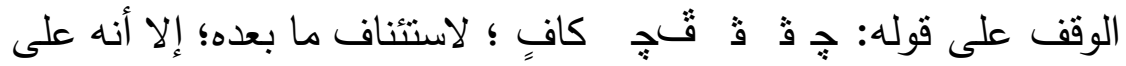

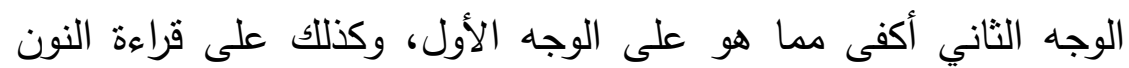

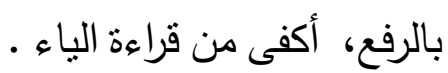
والوقف على وجه الاستئناف على كلا القراءتين: كافٍ عند الداني، ومطلقُ عند السجاوندي. وفرق الأشموني بين القراءتنين على وجه الاستئناف: فجله تاماً على قراءة النون، وكافٍ على قراءة الياء.

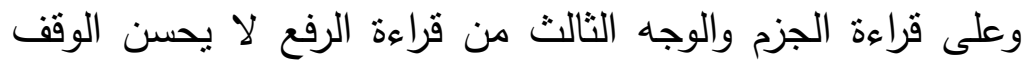

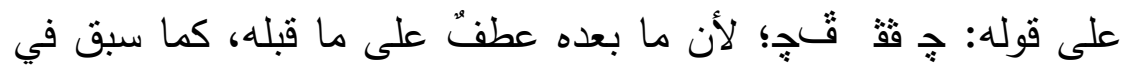

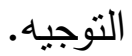
وقريباً من هذا على قراءة الجزم ذكره ابن غلبون والداني

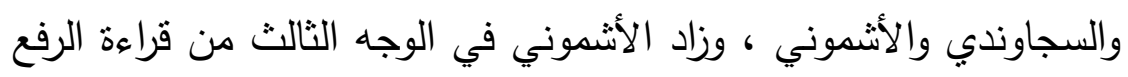
فقال: إلا أن يجعله من عطف الجمل؛ فيكون كافياًة (r).

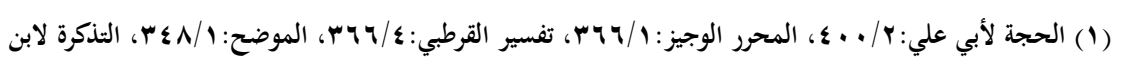

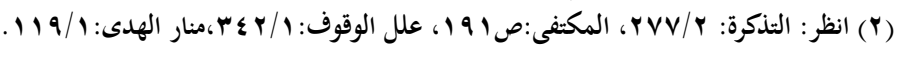


الموضع السادس

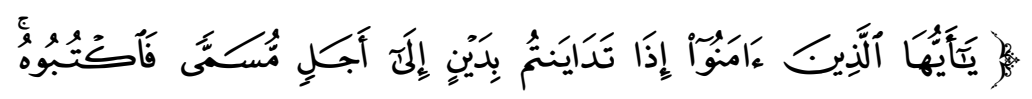

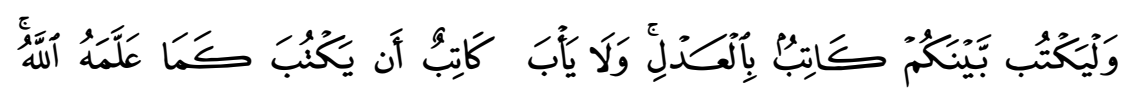

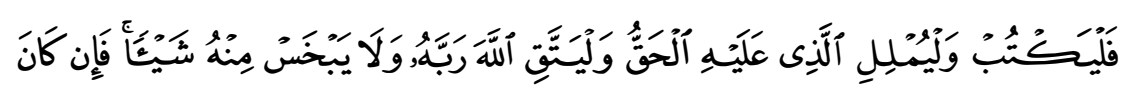

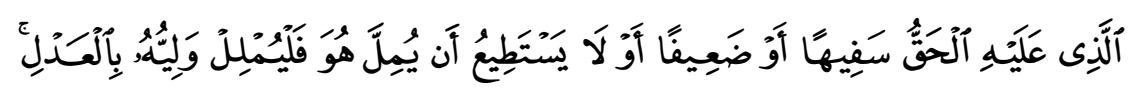

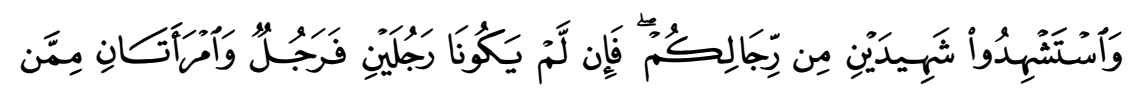

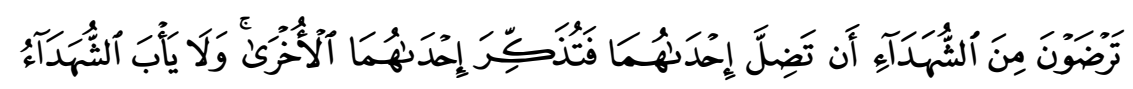

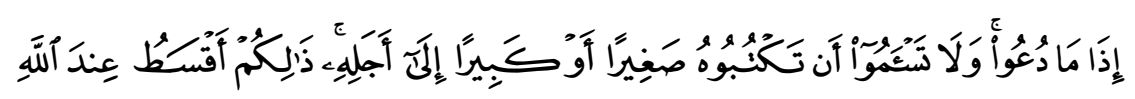

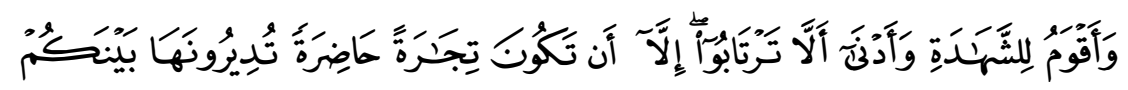

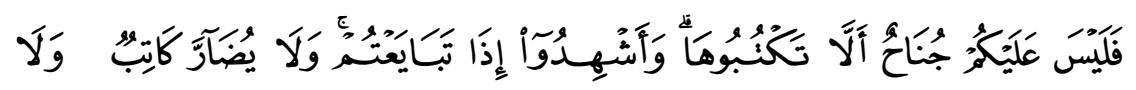

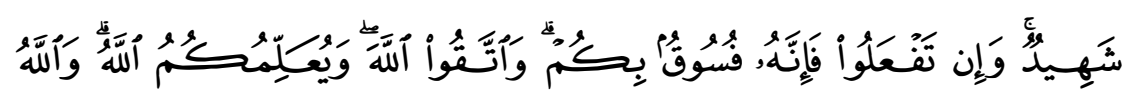

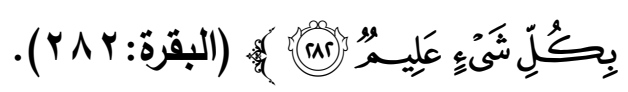

القراءات:

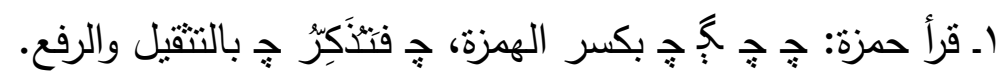

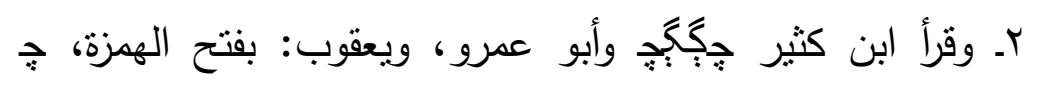

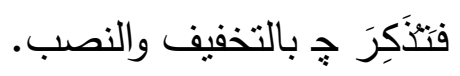

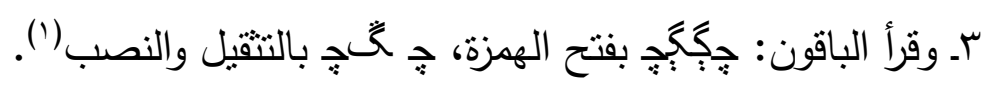

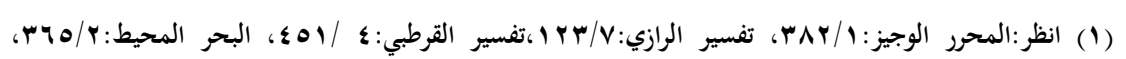

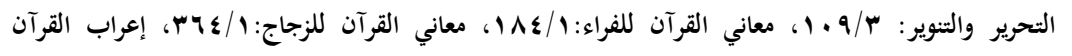


على حسب التوجيه الذي ذكر ، تكلم النحاس والأنصاري والأشموني

$$
\text { على الوقف والابتداء في هاتين القراءتني. }
$$

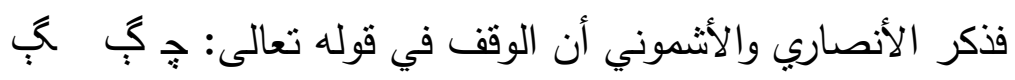

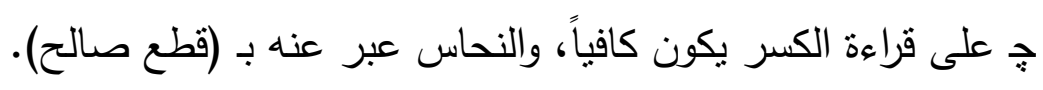

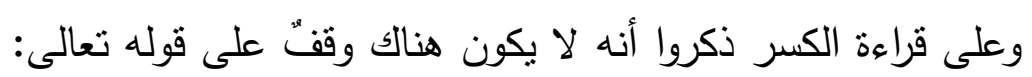

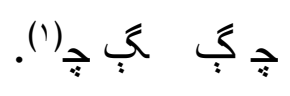

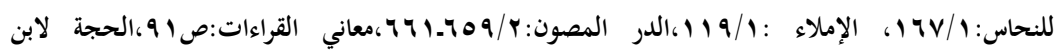

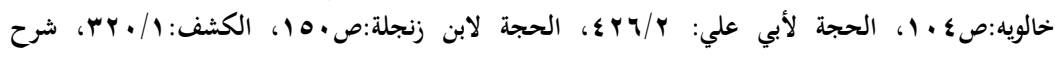

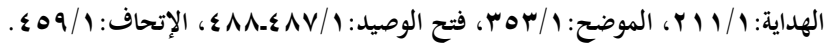

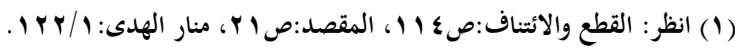




\section{الموضع السابع}

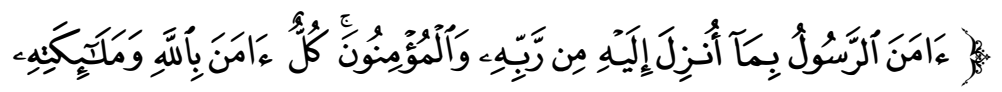

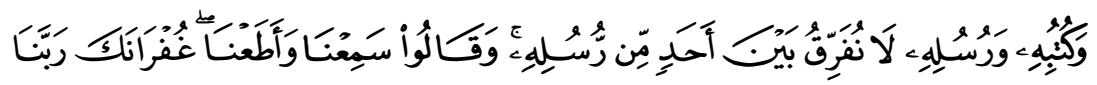

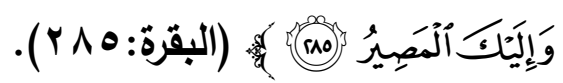

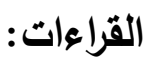

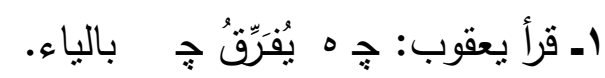

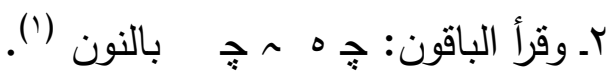

على حسب التوجيه الذي ذهر ذه ، تنكلم ابن الأنباري والداني

والسجاوندي والأنصاري والأشموني على الوقف والابتداء في القراءتين.

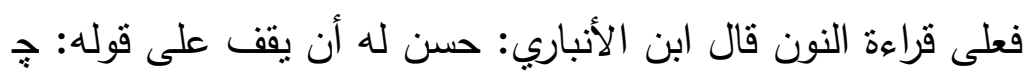

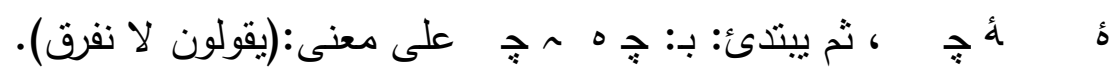

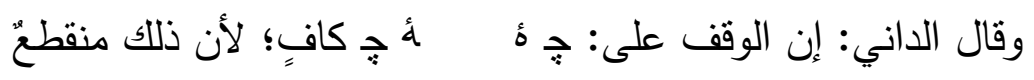

عما قبله.

وقال السجاوندي: إن الوقف على: جه هُ

$$
\text { لحق الحذف، أي:( يقولون لا نفرق). }
$$

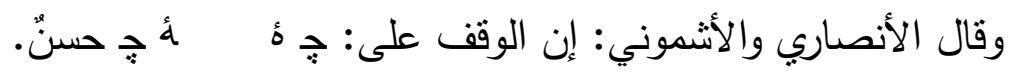

وعبارة ابن الأنباري والداني والسجاوندي مثقاربة؛ لأن ما ذكره ابن الأن النان

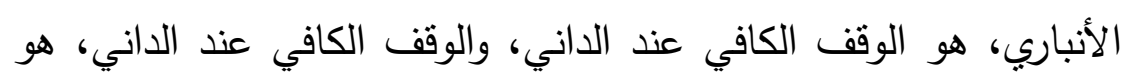

داخل في الوقف المطلق عند السجاوندي.

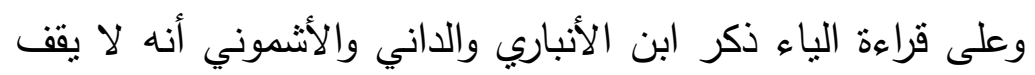

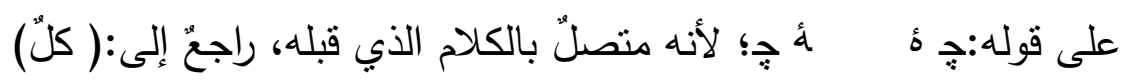

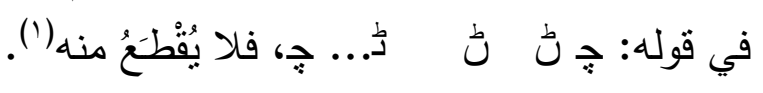

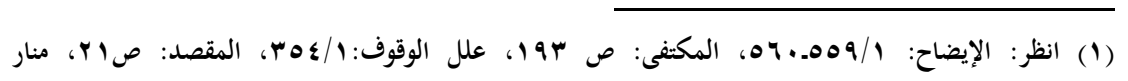


蓙

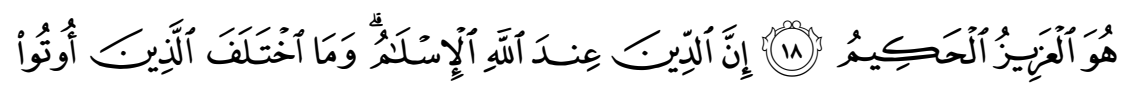

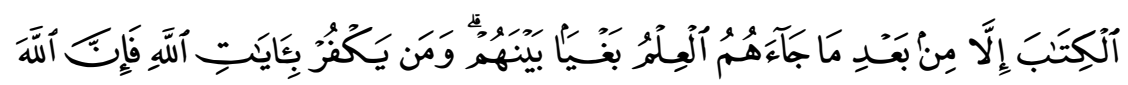

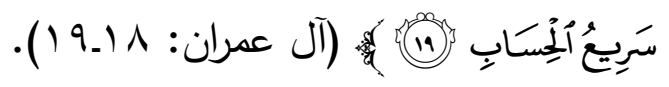

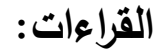

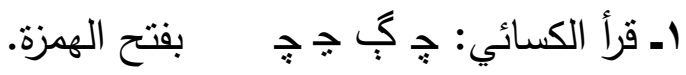

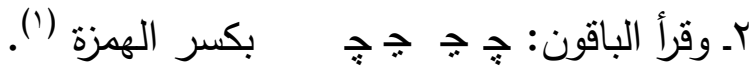

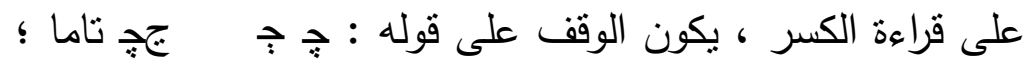

$$
\text { كما ذكر ابن الأنباري }
$$

والنحاس والداني والأنصاري والأشموني، ومطلقٌ عند السجاوندي ؛

لاستئناف ما بعده وعدم تعلقه به.

وعلى قراءة الفتح بأوجهها، لا يحسن الوقف على قوله : جه جـ

جج ، إئلا يفصل بين

العامل ومعدوله، أي:بين البدل والمبدل منه كما في الوجهين 
الأولين، وبين العطف والمعطوف عليه كما في الوجه الثالث.

وقربياً مما من هذا، قاله الذين تقدم ذكرهم ـ في الوقف على قراءة

الكسر- ؛ إلا أنهم ذكروا ذلك على بعض الأوجه ، ولم يحصروا جميع

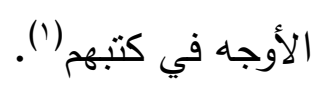

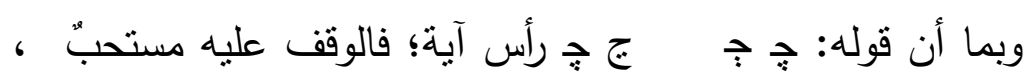

وهو مذهب الداني والهذلي وابن الجزري والأشموني •

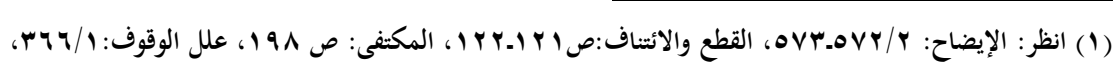

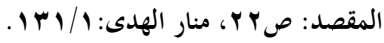




\section{الموضع التاسع}

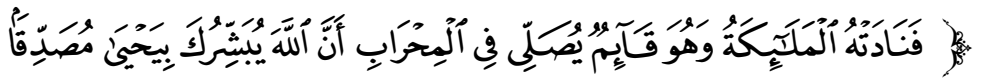

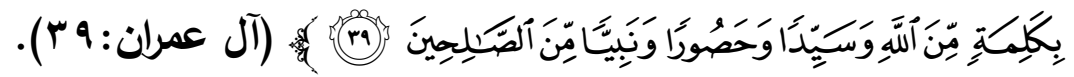

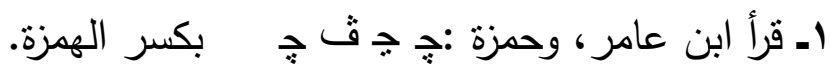

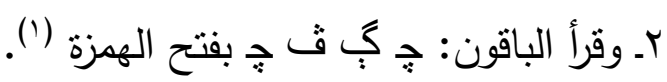

على وجه إضمار القول من قراءة الكسر ـ وهو الوجه الأول ـ ذ ذكر لهر

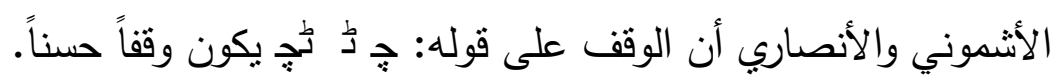

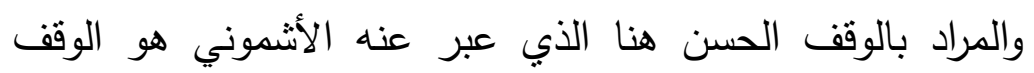

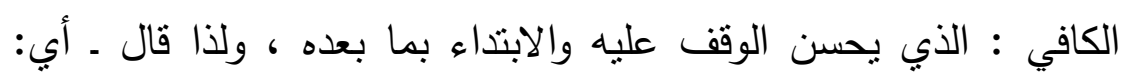

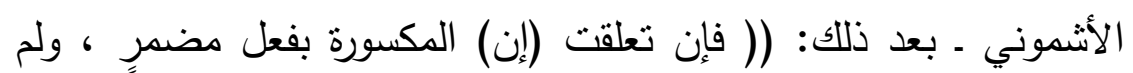

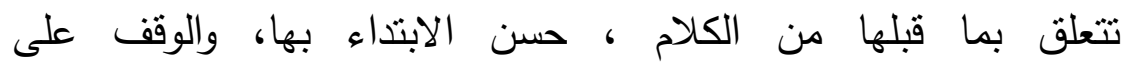

ما قبلها () ().

وعبارته هذه هي تعريف الوقف الكافي عند الداني.

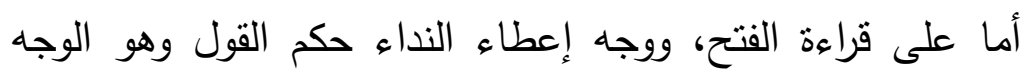

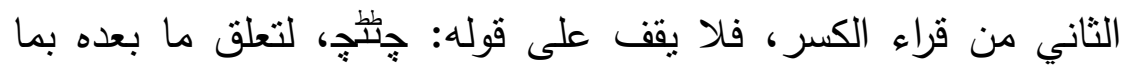

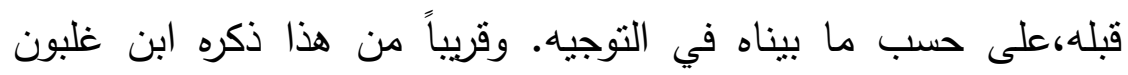

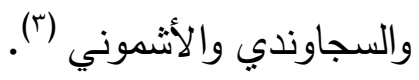


الموضع العاشر

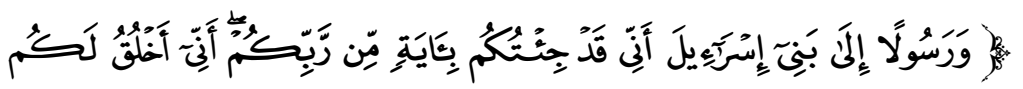

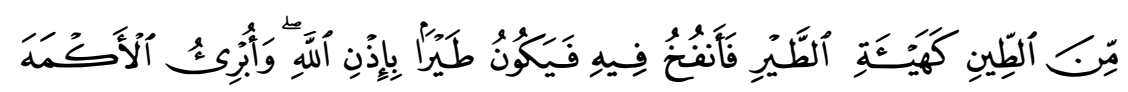

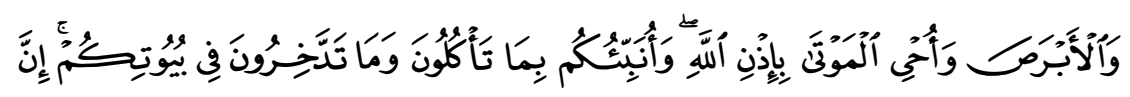

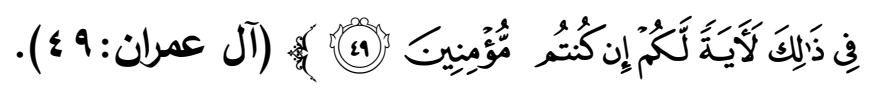

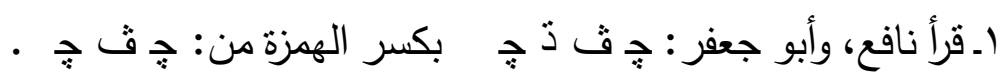

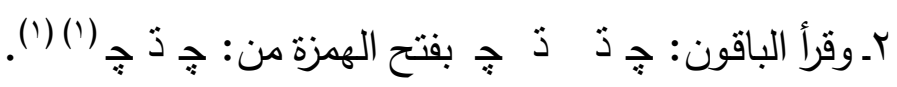

على وجهي الاستئناف والتفسير من قراءة الكسر : يكون الوقف على هلى

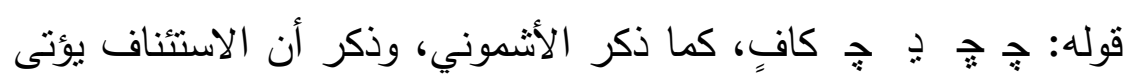
به تفسيراً لما قبله. وذكر الداني وابن غلبون أنه على وجه الاستئناف

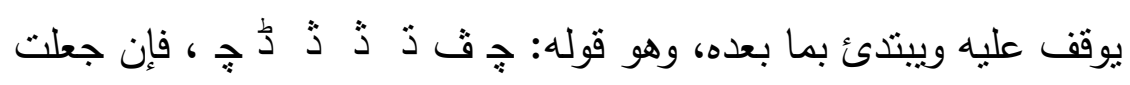
تفسيراً لم يقف عليها ولا يبتدئ بها (r). وعلى الوجهين الأخيرين من قراءة القتح يكون الوقف على قوله:ج

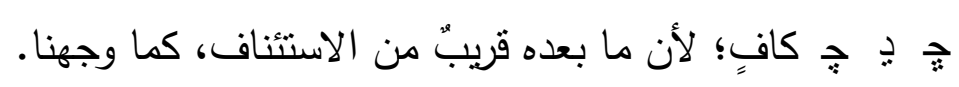
وكذلك على وجه إضمار القول من قراءة الكسر، يكون الوقف عليه

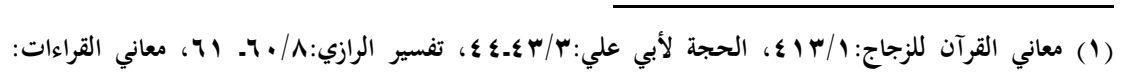

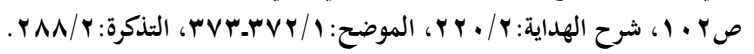

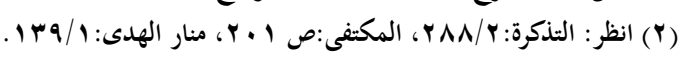




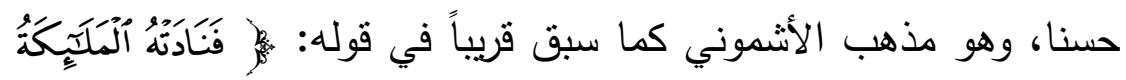

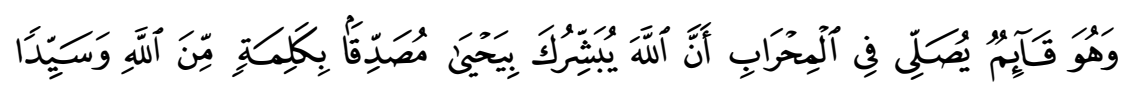

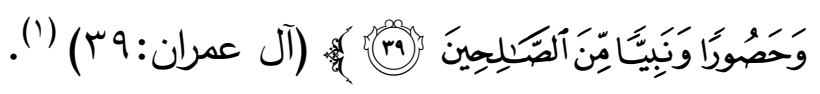

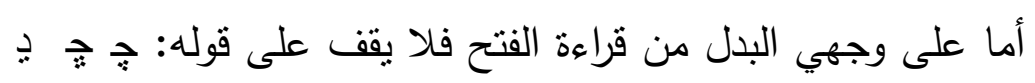

ج ، ولا يبتدئ بما بعده؛ لئلا يفصل بين البدل والمبدل منه (r). 
الموضع الحادي عشر

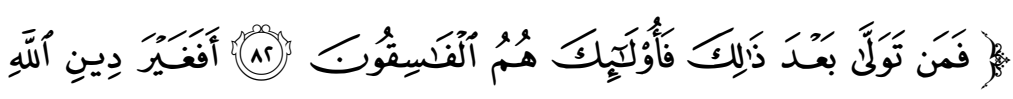

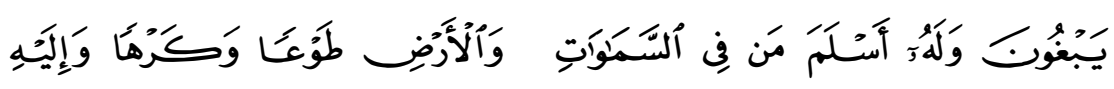

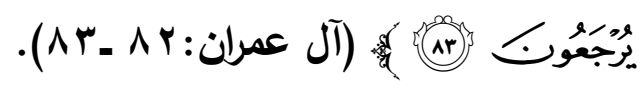

القراء|ت:

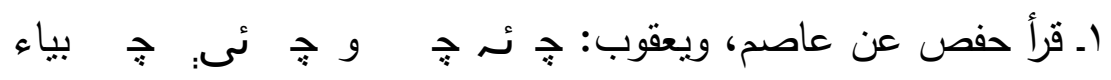

$$
\text { الغيب فيهما. }
$$

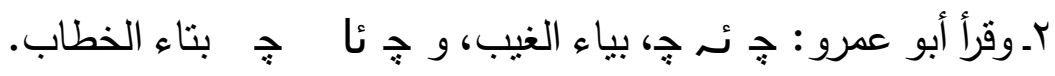

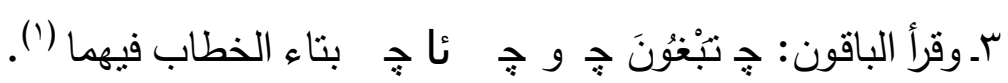

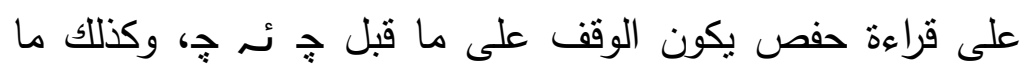

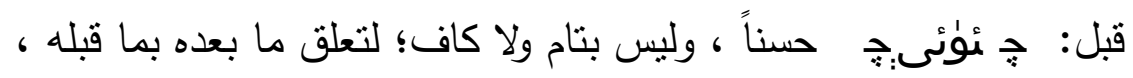
من حيث الإخبار عن قضية متصلة.

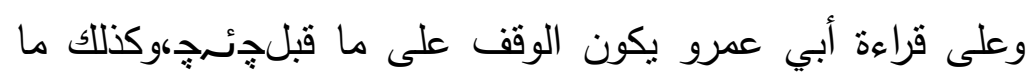

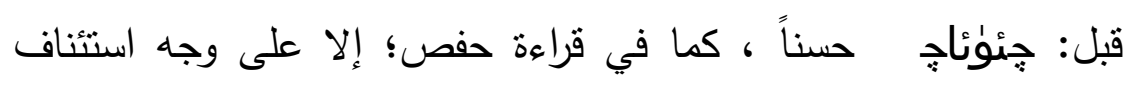
الخطاب في:جئؤئا جٍ فيكون الوقف كافٍ ؛ لكونها جملة مستأنفة.

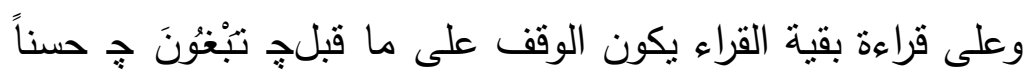

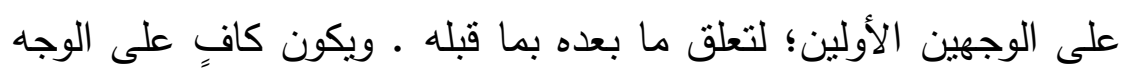
الثالث؛ لاستئنافه.

ويكون الوقف على ما قبل : جِئؤئاجٍ حسناً ، على الوجهين؛ لتعلق ما بعده بما قبله .

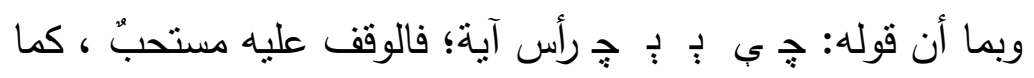
هو مذهب الداني والهذلي وابن الجزري والأشموني، وغيرهم. 


\section{الموضع الثاني عشر}

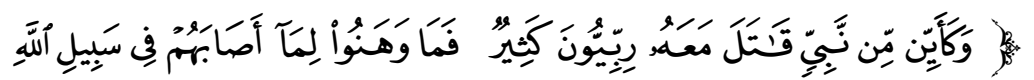

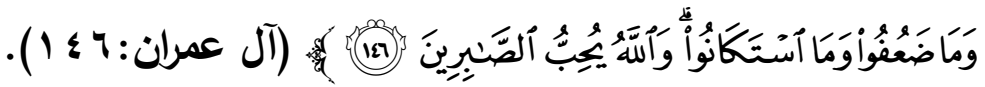

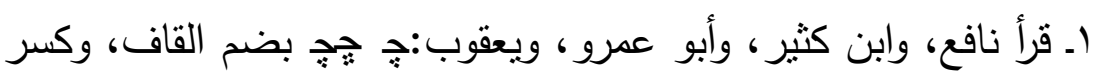

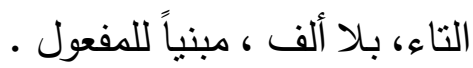

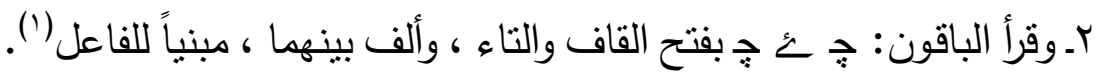

\section{لوقف والابتداء حسب التوجيه:}

هذا الموضع قد تكلم فيه من حيث الوقف والابتداء كثيرٌ من

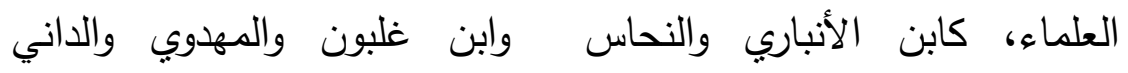

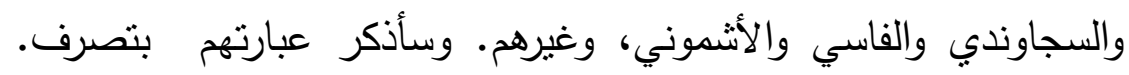

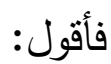

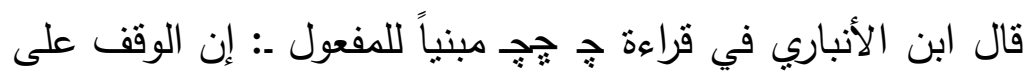

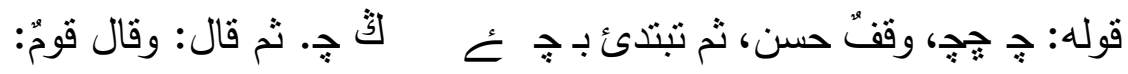

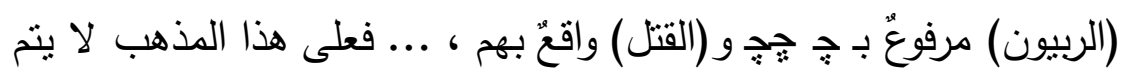

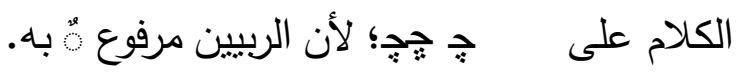

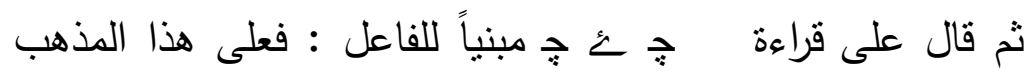
لا يتم الوقف على قاتل ؛ لأنه فعل للربيين. ويقصد بالوقف الحسن الذي ذكره الوقف الكافي، يقول الفاسي: 


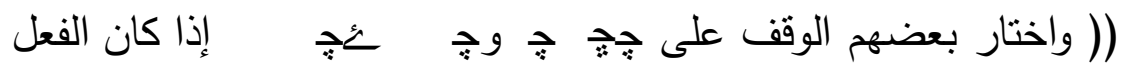
مسنداً إلى المضمر لبيان المعنى ، قال ابن الأل الأنباري : وهو

$$
\text { حسن، وأراد بالحسن الكافي)(ان). }
$$

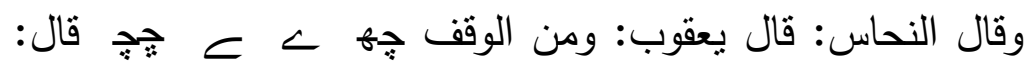

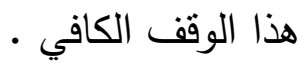

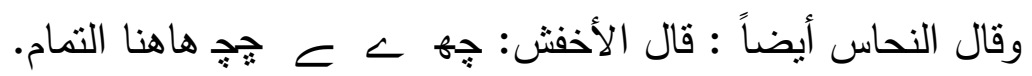

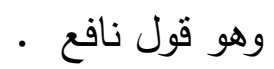

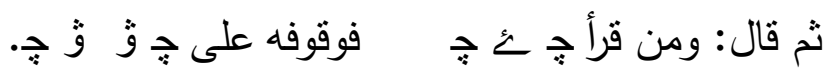

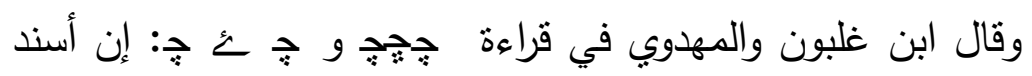

الفعل إلى النبي

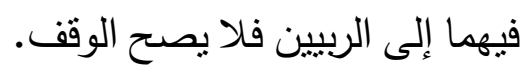

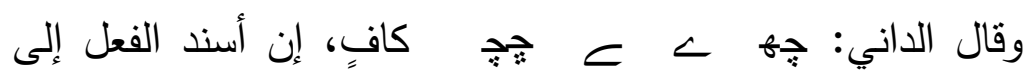
النبي

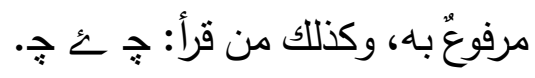

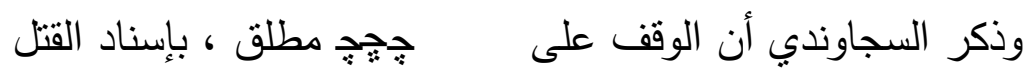

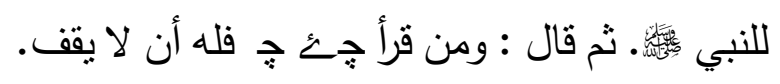

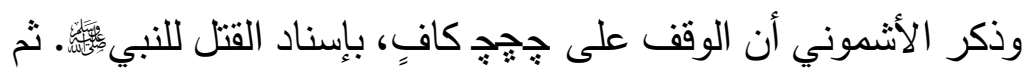

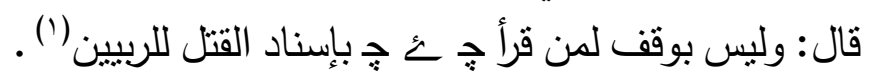

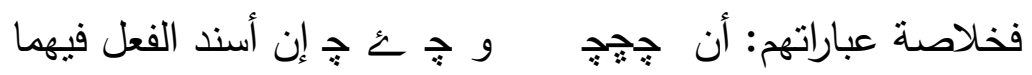

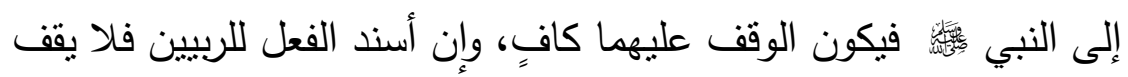

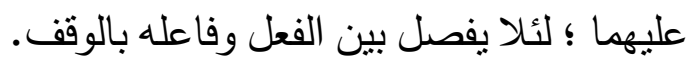

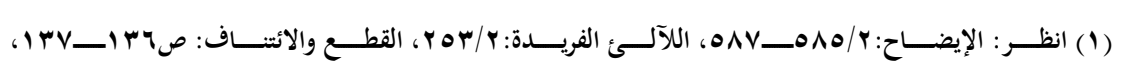

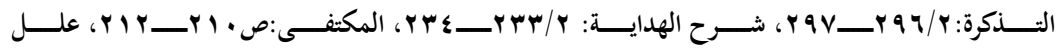

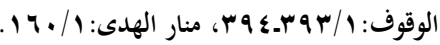




\section{الموضع الثالث عشر}

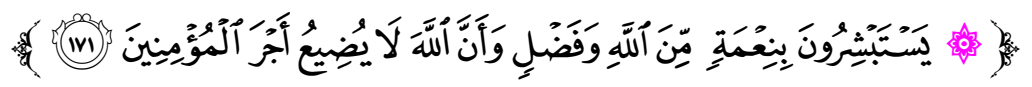

$$
\text { (IVI) (IV) (آل عمران) }
$$

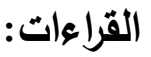

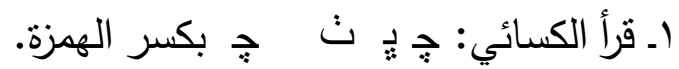

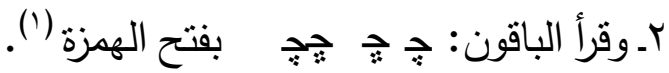

على قراءة الكسر ، يكون الوقف في قوله: جِ وُو جٍ كافٍ؛ لاستئناف

ما بعدها على الابتثاء، وعدم تعلقها بما بعدها. وهذا عند النحاس والداني.

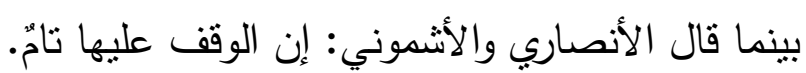

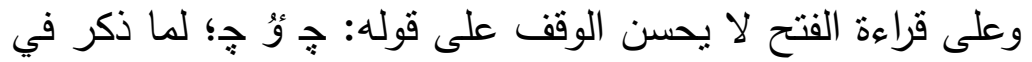

التوجيه، من كونه معطوفاً على ما قبله (؟).

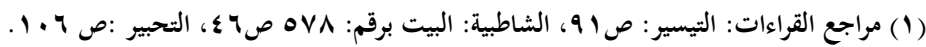

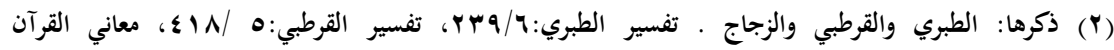

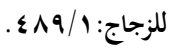




\section{الموضع الرابع عشر}

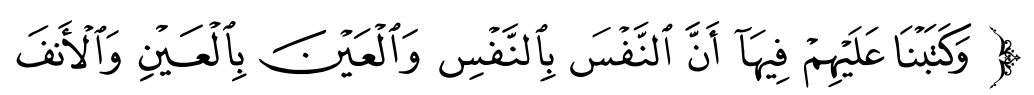

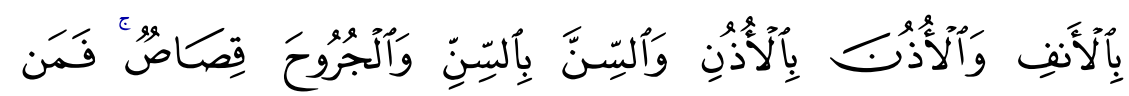

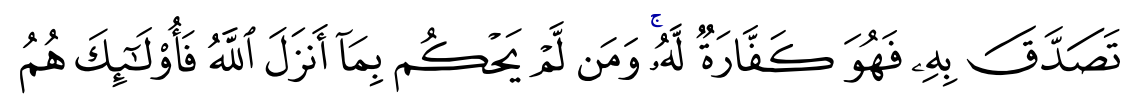

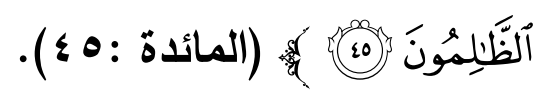

القراءات:

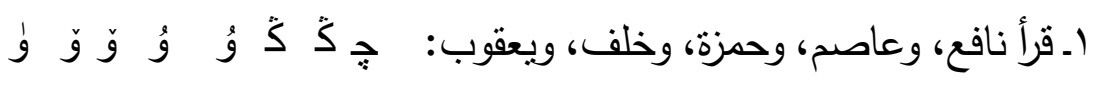

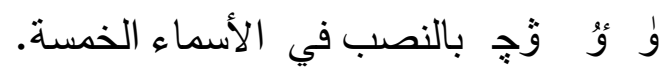

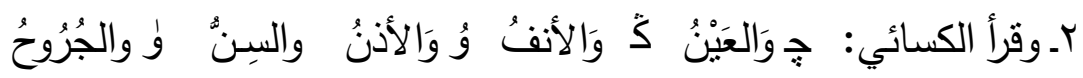
وُجه بالرفع في الأسماء الخمسة.

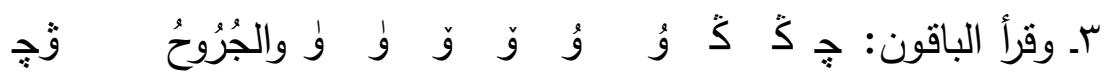

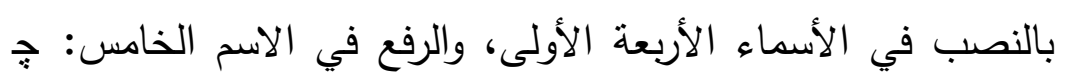

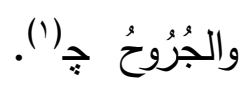

على قراءة نافع ومن معه، والوجهين الأخيرين من قراءة الكسائي

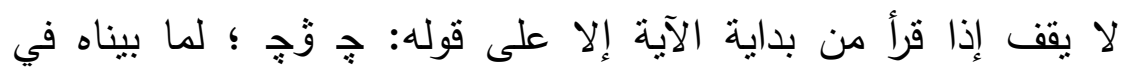
التوجيه. وعلى الوجه الأول من قراءة الكسائي يكون الوقف على قوله: جه آث

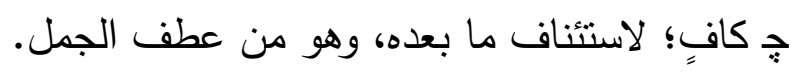

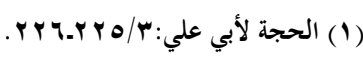


وعلى قراءة بقية القراء لا يقف إذا قرأ من بداية الآية إلا على قوله:

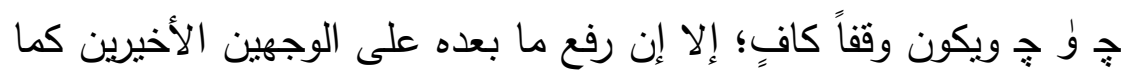

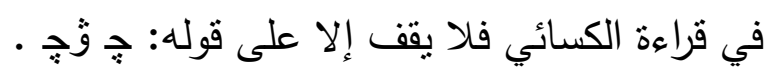
وما عبر عنه بالوقف الكافي في القراءتين السابقتين ، عبر عنه

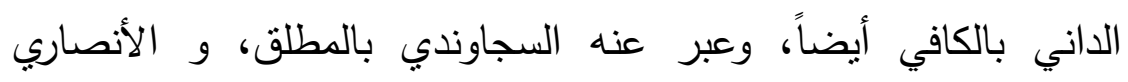

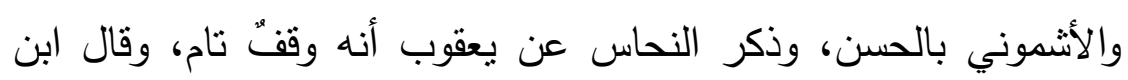
الأنباري : يحسن الوقف عليه ويبتدئ بما بعده.

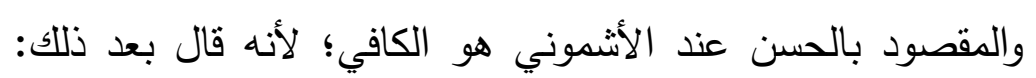
فجعله مستأنفاً مقطوعاً عما قبله. 


\section{الموضع الخامس عشر}

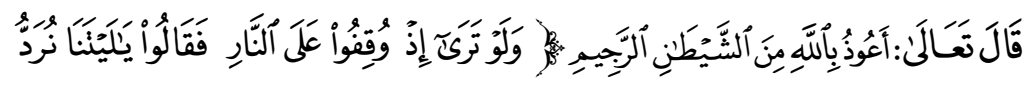

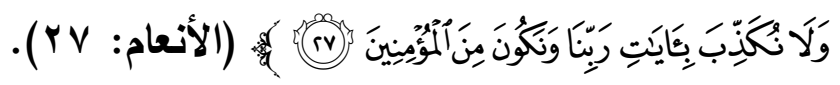

اـ قرأ حفص عن عاصم، وحمزة، ويعقوب : ج سخ ج ؛ ، و ج صم ج) بنصبهما.

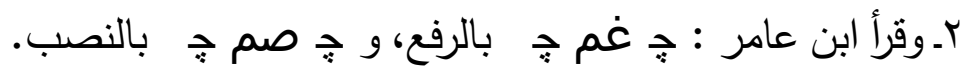

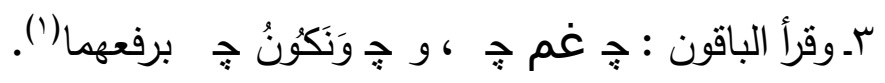

في وجه القطع والاستئناف من قراءة رفع الفعلين ، ذكر الأنصاري

$$
\text { والأشموني : أن الوقف على اله واله }
$$

قوله: جֶسج ج: جائز • وقال ابن غلبون:(( فعلى هذا يجوز الابتداء

$$
\text { بهما؛ لأنهما مستأنفان ()). }
$$

وليس بوقف على قراءة نصبهما جواباً للتمني، ولا على قراءة رفعهما عطفاً على جهسج جٍ ، أو في موضع نصبٍ على الحال ؛ لأن الجميع داخلٌ في التمني. ولا على قراءة رفع الأول ونصب الثاني؛ لئلا يفصل بين

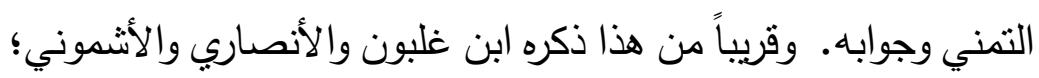

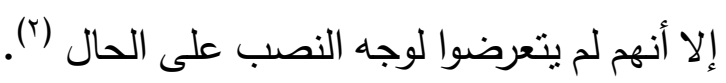


الموضع السادس عثر

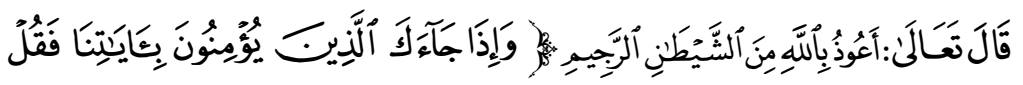

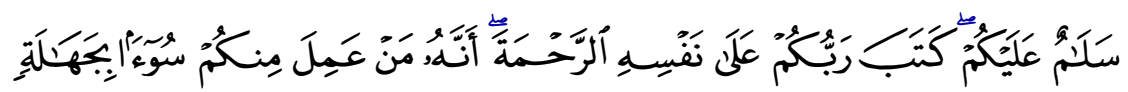

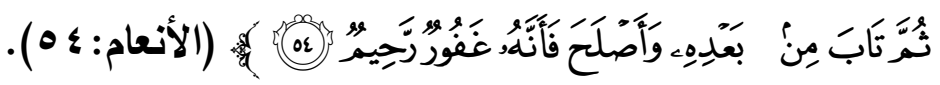

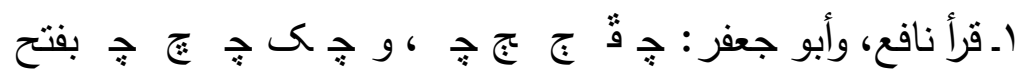

الههزة في الأولى ، والكسر في الثانية .

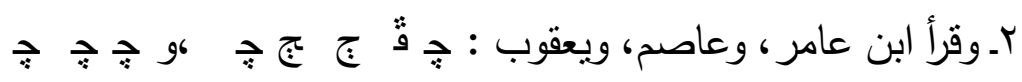

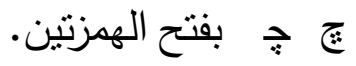

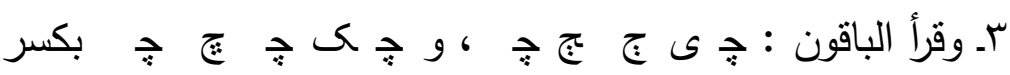

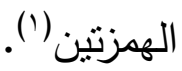

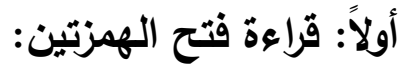

فمن قرأ بفتح الههزتين لم يقف على ما قبل الأولى، ولا على ما قبل

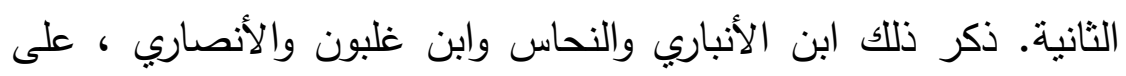

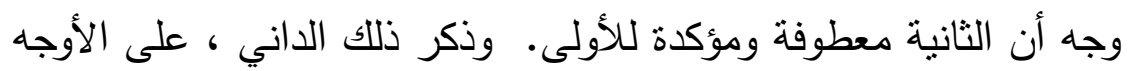
الثثلاثة في الهمزة الثانية ؛ لأن الفاء المتصلة بها جواب (من) ، ولا يفصل

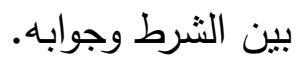
وذكر ذلك الأشموني على وجه أن الثانية معطوفة على الأولى، أما 


\section{إن جعل الثانية خبر مبتدأ محذوف، فهو حسن. ثانياً: قراعة فتح الأولى وكسر الثانية:}

ومن قرأ بفتح الأولى وكسر الثانية ، لم يقف على ما قبل الأولى ،

ولا على ما قبل الثانية .

ذكر ذللك ابن الأنباري وابن غلبون والداني؛ لأن الفاء الاخلة على (من) الثانية، جواب الثرط.

ثالثاً: قراعة كسر الههزتين:

ومن قرأ بكسر الهمزتين، فإن جعل الكسر في الأولى على

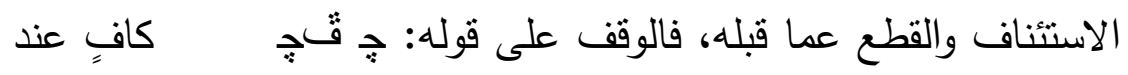
الأنصاري والأشموني. وقال الداني: كان كافياً بالغاً. وذكر النحاس: أنه وقفٌ تمام. ويقصد بالتمام: الوقف التام. وذكر ابن الأنباري وابن غلبون:

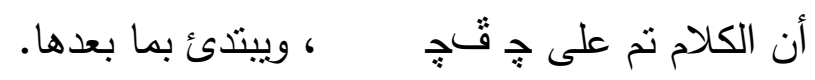
وإن جعل الكسر في الأولى على وجه أن (كتب) بمعنى (قال)، لم

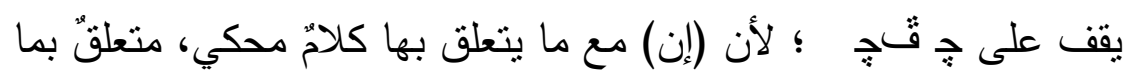
قبله. ذكر ذلك ابن الأنباري والنحاس والداني. وإن جعل الكسر في الأولى على أنها تفسيراً لـ (الرحمة) لم يقف أيضاً عليها؛ لأن ما بعدها متعلقُ بها. ذكر ذلك ابن غلبون والداني. ولم يتكلم الأشموني على وجه جَعْلِ (كتب)بمعنى (قال)، ولا على وجه التفسير لـ جُقٌ . ولكن مذهبه هنا في وجه التفسير يقاس على ما ذكره في الموضع السابع من سورة آل عمران، في قوله تعالى: 


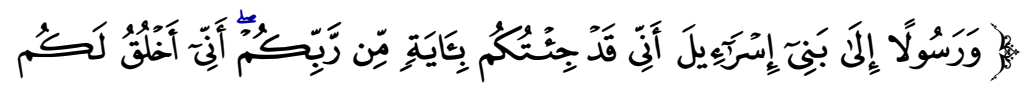

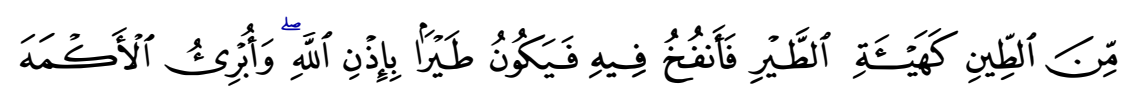

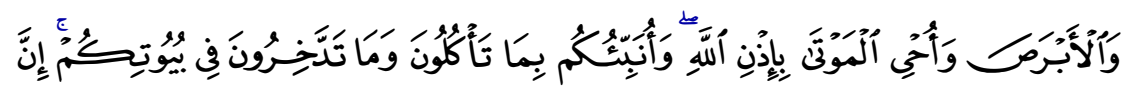

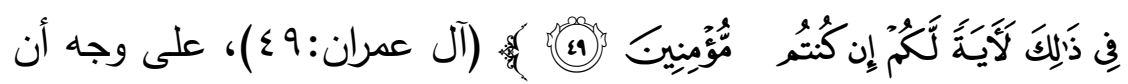

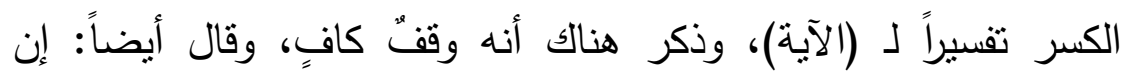

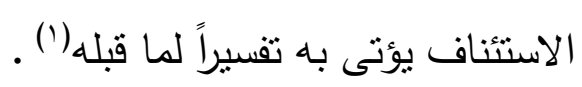

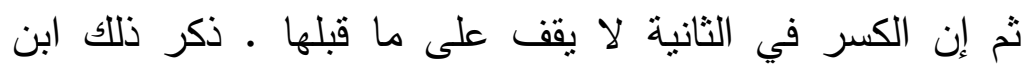

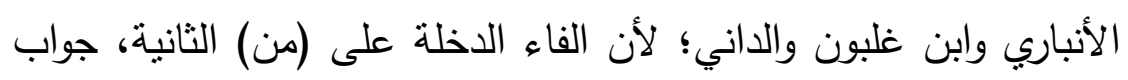

الثرط (r).

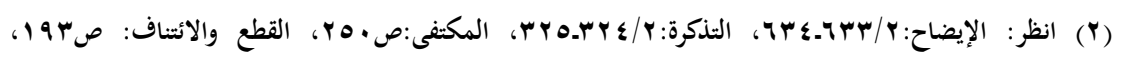


الموضع الثامن عشر

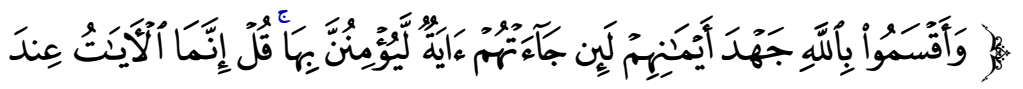

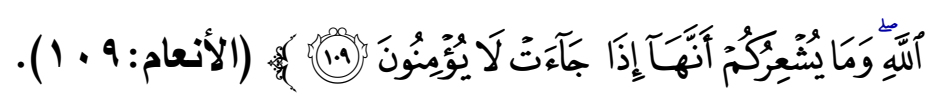

القراعات:

اـ قرأ ابن كثير، وأبو عمرو، وشعبة عن عاصم بخلف عنه،

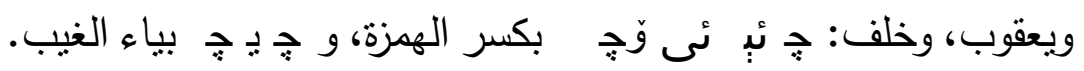

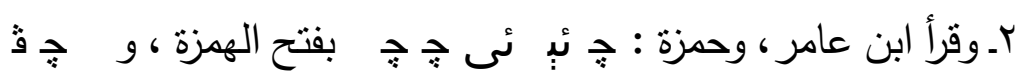

ج ج بتاء الخطاب

rــ وقرأ بقية القراء - نافع، وعاصم بخلف عن شعبة، والكسائي، وأبو

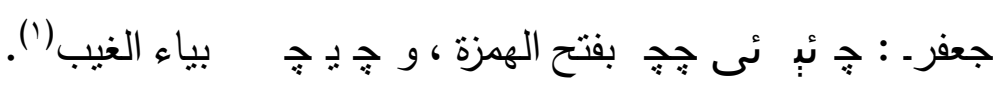

على قراءة كسر الهمزة - وهي قراءة ابن كثير- يكون الوقف على

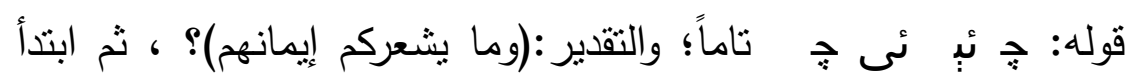

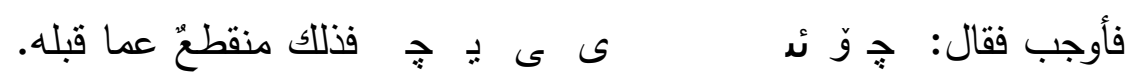
ذكر هذا الداني.

وهو وقف تام عند : الداني والأنصاري والأشموني، ويعقوب كما نقل

عنه النحاس. ومطلقُ عند السجاوندي. وذكر ابن الأنباري وابن غلبون أنه يقف ويبتدئ بما بعده.

وقد روى الداني بسنده إلى قنبل أنه قال: ((سمعت أحمد بن محمد 
القواس يقول: نحن نقف حيث انقطع النفس إلاًّ في ثثلاثة مواضع، نتعدد

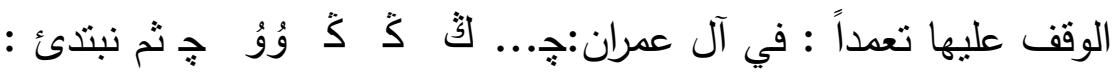

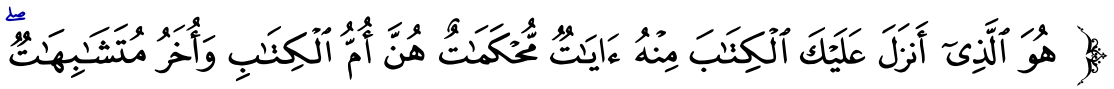

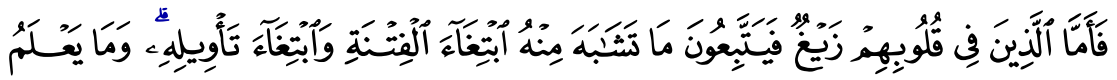

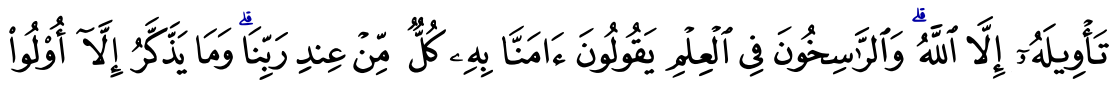

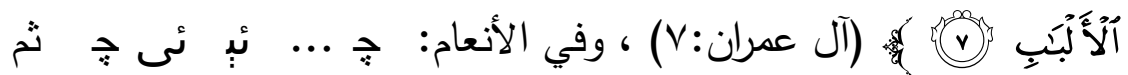
نبتدئ:

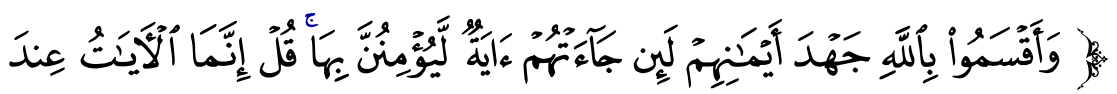

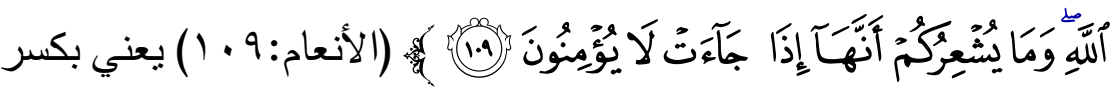

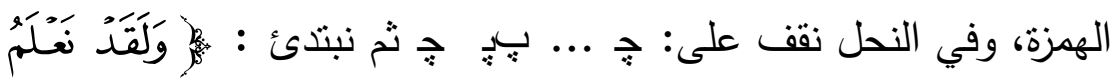

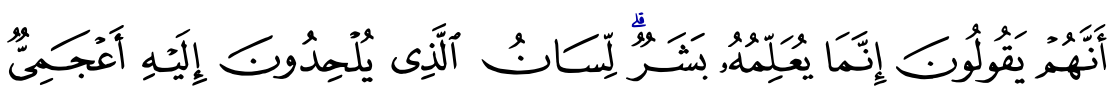

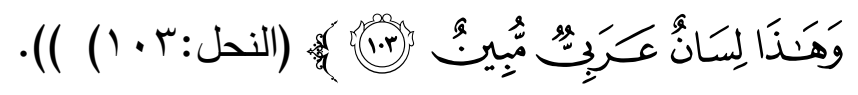

أما قراءة الفتح، فعلى وجه: أن ج ج ج ج بمعنى (لعلَّ) ، فذكر ابن

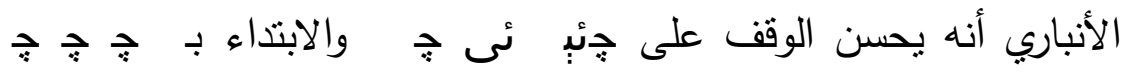
مفتوحة.

وذهب النحاس إلى جواز الوقف على هذا الوجه.

وقال ابن غلبون:(( فعلى هذا يجوز الابتداء بها؛ لأنها مستأنفةٌ، فقد تم الكلام دونها، كأن التقدير: (وما يشعركم إيمانهم)؟ ثم إنه ابتدأ فقال:(لعلها إذا جاءت لا يؤمنون)، على معنى نفي الإيمان عنه)). 
وقال الأشموني في هذا الوجه: أنك تقف عليه كما وققت في

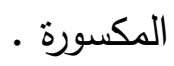

وذهب الداني إلى عدم الوقف؛ لأنها متعلقة بما قبلها، فلا تقطعُ

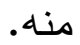

أما على بقية أوجه القتح: فلا يقف على ما قبل: جه جٍ ج؛؛ لما بيناه

في التوجيه، من كونها متعلقة بما قبلها، فلا يقطع بينهما. وهذا قول ابن

الأنباري والنحاس وابن غلبون والداني والأنصاري والأشموني (').

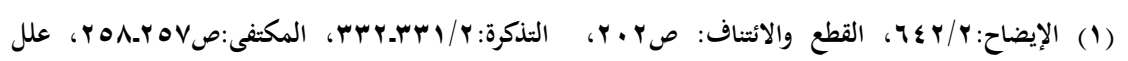

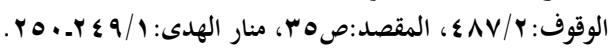


الموضع التاسع عشر

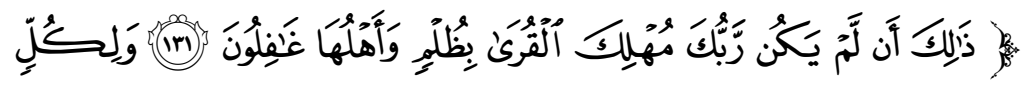

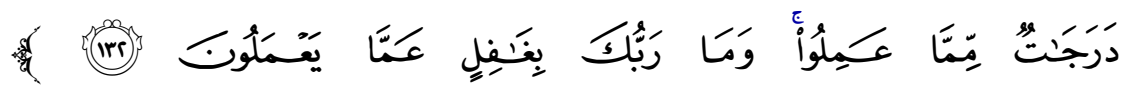

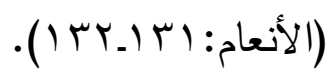

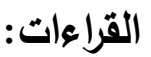

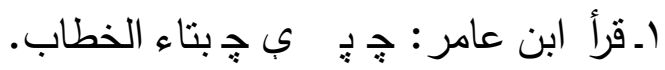

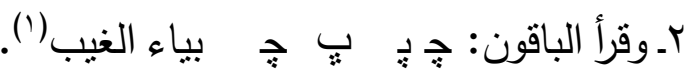

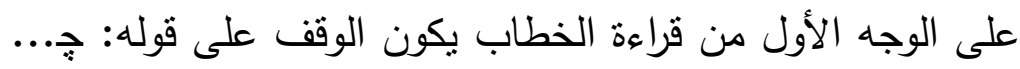

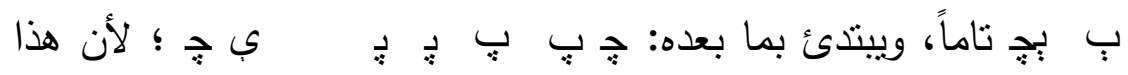

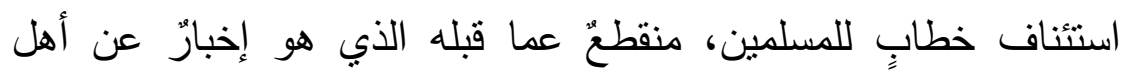

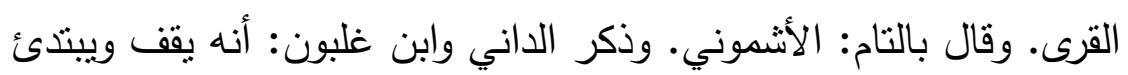
بما بعده. - مان.

وعلى قراءة الغيب، ذكر ابن غلبون والداني والأشموني: أنه لا يقف

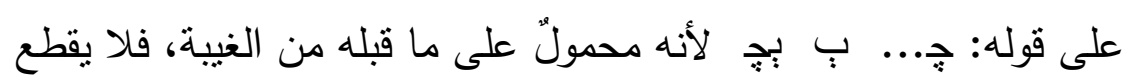
بعضه من بعض (r) (r). ولكن أرى أن الوقف على قراءة الغيب، وكنلك على الوجه الثاني

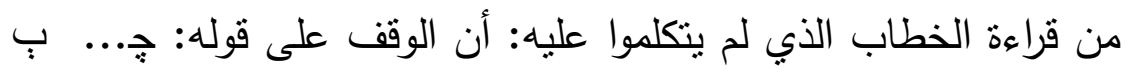

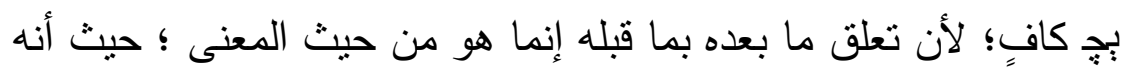

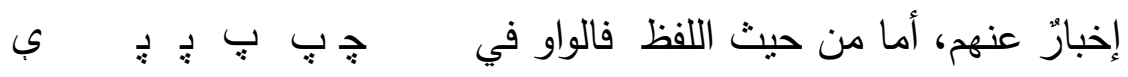
ج جلاستئناف، أو من عطف الجمل. واله تعالى أعلم. 


\section{الموضع العثرون}

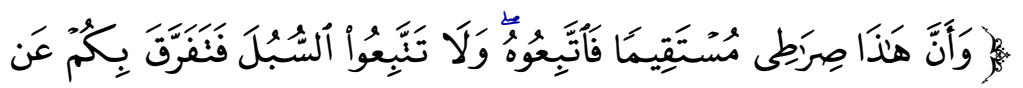

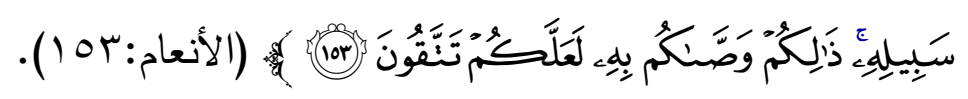

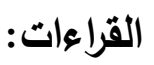

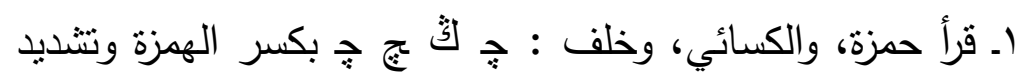

rـ وقرأ نافع، وابن كثير ، وأبو عمرو، وعاصم، وأبو جعفر : جع جَج

بفتح الهمزة وتشديد النون •

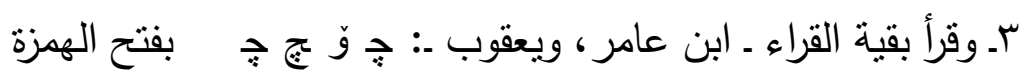

$$
\text { وتخفيف النون (') }
$$

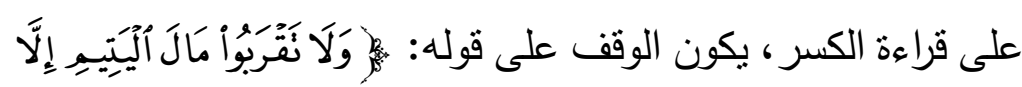

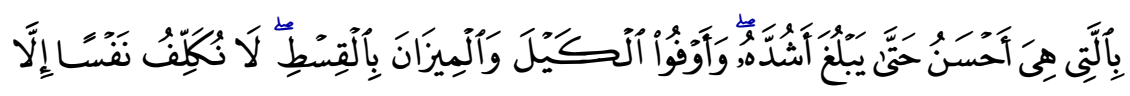

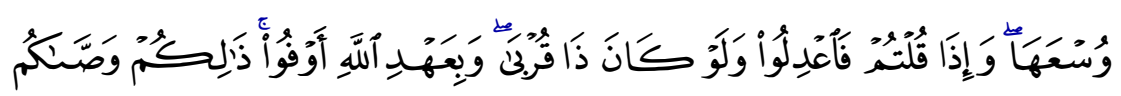

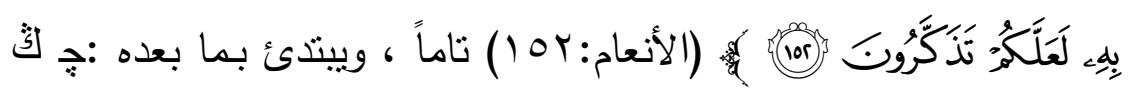

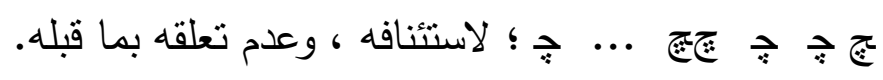
وذهب إلى أن الوقف عليه تامُ: ابن الأنباري والداني والأشموني. وعند

$$
\text { النحاس: كافٍ، والسجاوندي: مطلقُ. }
$$

وكذلك يكون الوقف تاماً على الوجه الأول من قراءة الفتح، على تقدير

لام العلة، أي:( ولأن هذا صراطي مستقيماً فاتبعوه)، فهو غير متعلق بما قبله، كما ذكر في التوجيه. وهذا الوجه لم يتكلموا عليه من حيث الوقف 
والابتداء؛ لعدم ذكره في كتبهم.

وعلى الوجهين الأخيرين من قراءة الفتح ذكر النحاس والداني

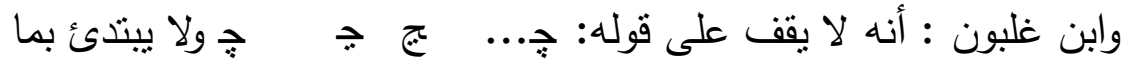
بعده ؛ لتعلقه بما قبله ، إما أنه معطوفُ على الهاء، أو (أتل) كما سبق في التوجيه. وقال الأشموني منل هذا؛ إلا أنه ذكر ذلك على وجه عطفه على (أنل) . ولم يتكلم على الوجه الآخر • وقال ابن الأنباري في كلا الوجهين: لا يتم الوقف على قوله: ج...

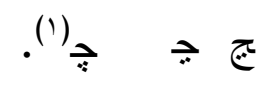

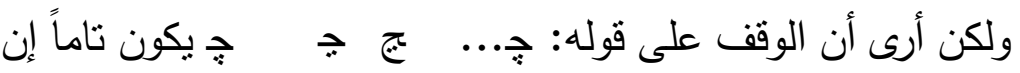

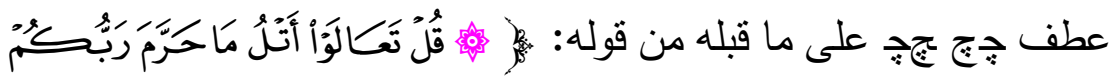

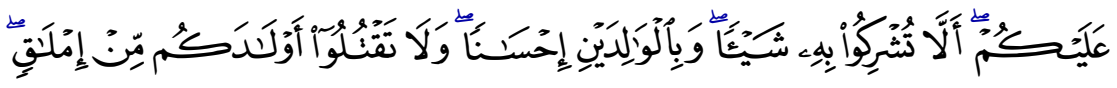

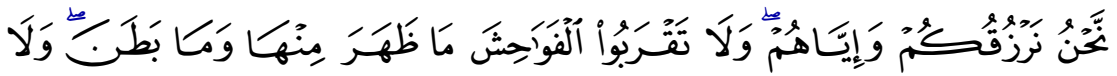

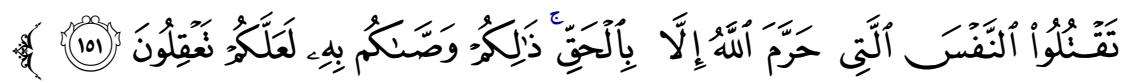
(الأنعام: 10 (1))؛ لطول الفصل بينهما، كما هو بينٌ. وبما أن قوله: جֶ.. مستحبٌ. والله تعالى أعلم. 


\section{الموضع الحادي والعشرون}

象

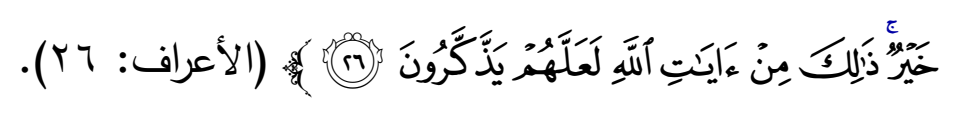

القراعات:

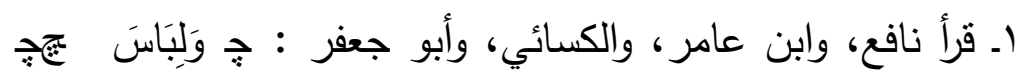

$$
\text { بنصب جِ وَلِبَاسَ جُ. }
$$

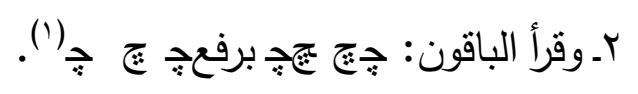

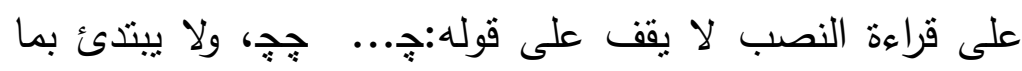

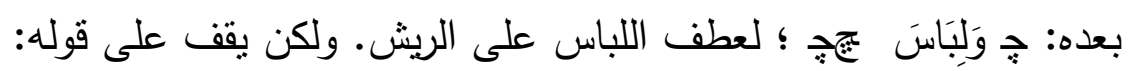

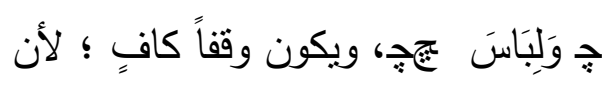
ما بعده جملة استئنافية من مبتدأ وخبر، غير متعلقة بما قبلها من حيث الإعراب. وذكر النحاس والسجاوندي: أنه يقف على قوله: جِ وَلَبَاسَ تج) إن قرئ بالنصب. ولم يبينا درجة الوقف.

كافٍ ؛

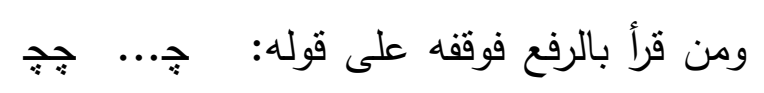

لاستئناف ما بعده ، وعدم تعلقه بما قبله من حيث الإعراب. وهو كافٍ

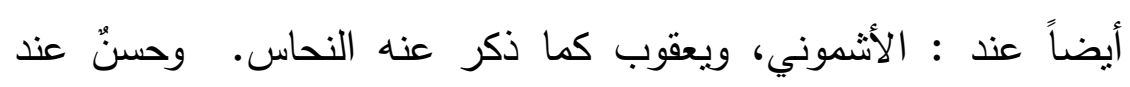
الأنصاري. وذكر ابن الأنباري وابن غلبون والداني والسجاوندي: أنه يحسن الوقف عليه، ويبتدئ بما بعده. ولم يبينوا درجته (r).

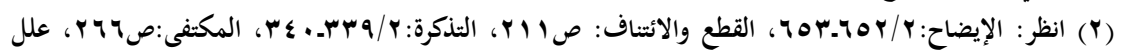

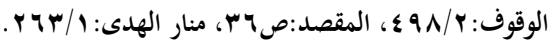


ثم إنه على قراء الرفع يكون الوقف في قوله: جِ جَجْ كافٍ، على

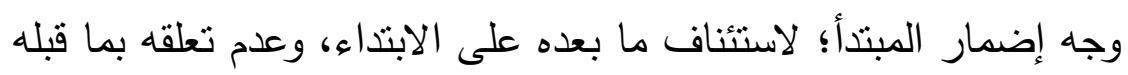
من حيث الإعراب.

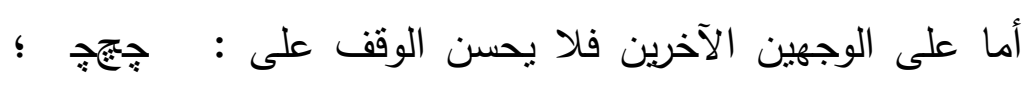
لتعلقه بما قبله من حيث الإعراب. كما ذكر في التوجيه. والله تعالى أعلم. 


\section{الموضع الثاني والعشرون}

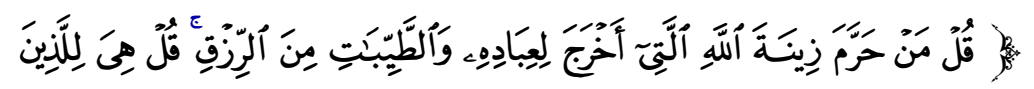

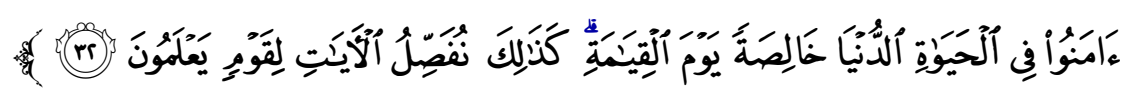

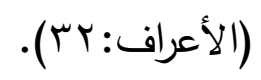

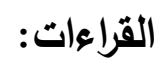

ו ـ قرأ نافع: جٍ تج جبالرفع.

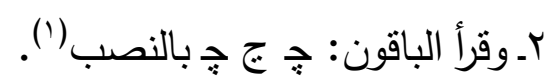

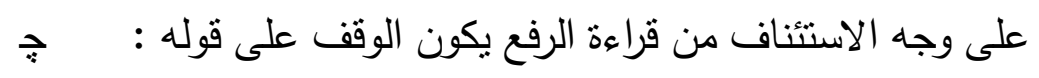

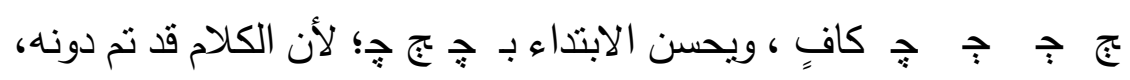
وهو منقطعٌ مما قبله ـ كما سبق في التوجيه. وقال الأشموني: إن الوقف حسن. وقال الأنصاري: كافٍ عند بعضهم • وقال ابن غلبون والداني: إنه يقف. ولم يبينا درجته. وعلى قراءة النصب والوجهين الآخرين من قراءة الرفع: لا يقق على

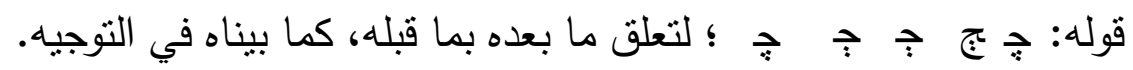
وذكر منل هذا في قراءة النصب ابن غلبون والداني والأنصاري والأشموني، ولم يتعرضوا للوجهين الآخرين من قراءة الرفع(ب).

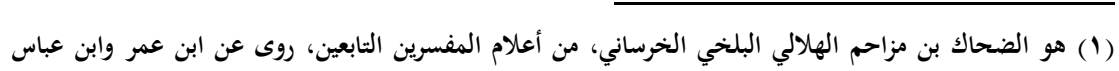

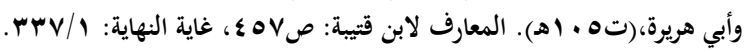

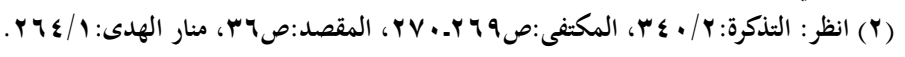


الموضع الثالث والعشرون

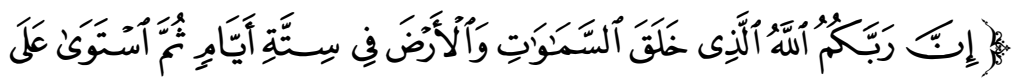

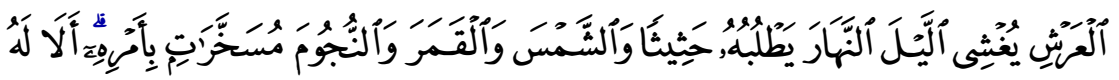

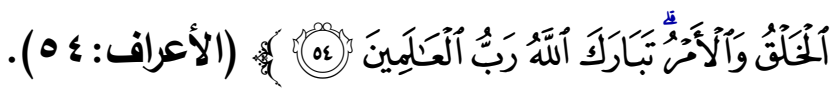
القراعات : - 2

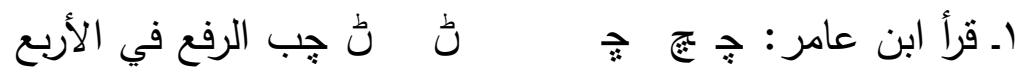
الكلمات.

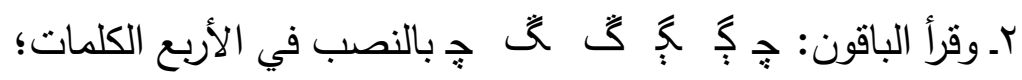
إلا أنهم كسروا التاء من:ج گَ ج؛ لأنه جمع مؤنث سالم، المنصوب بالكسرة نيابة عن الفتحة (1) على قراءة الرفع ، ووجه إضمار (جعل) في قراءة النصب يكون

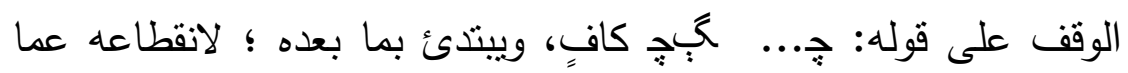
قبله، وعدم تعلقه بما قبله من حيث الإعراب. وفي قراءة الرفع قال السجاوندي: مطلقٌ. وقال الأنصاري والأشموني: حسنٌ. وقال ابن غلبون والداني: أنه يقف عليه، ويبتدئ بما بعده؛ لأنه مستأنف، ومنقطعٌ عما قبله. ولم يبينا درجته. وعبارتهما هذه تذل على الوقف الكافي.

وعلى وجه عطف: ( الثمسَ والقمرَ والنجومَ ) على قوله: ֶّ ذّ 


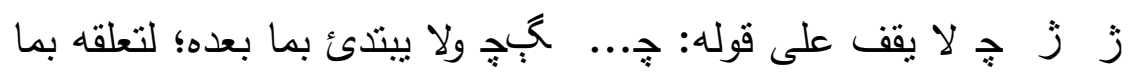
قبله من حيث الإعراب، فلا يقطع عنه. وقربياً من هذا،هو قول ابن غلبون والداني و الأنصاري

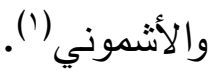


الموضع الرابع والعشرون

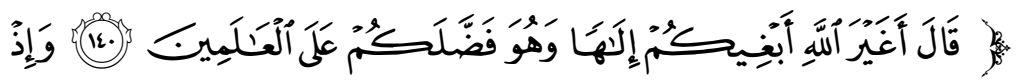

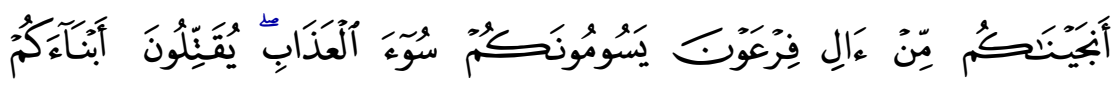

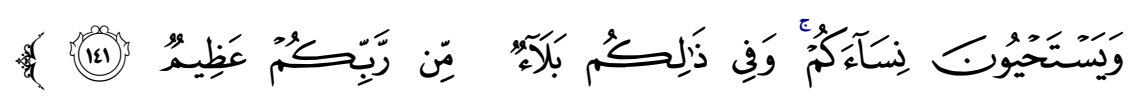

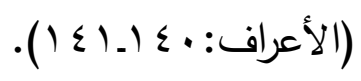

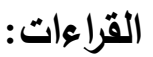

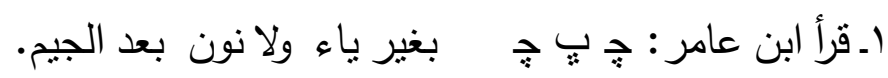

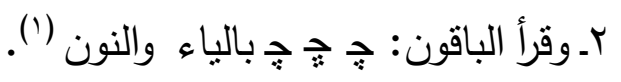

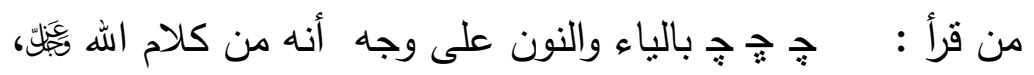

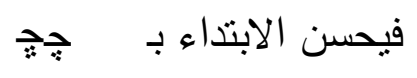

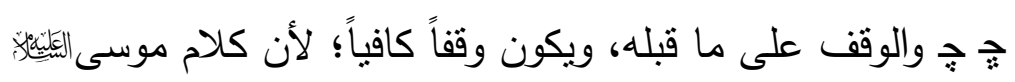

$$
\text { قد نم دونه، ثم استأنف }
$$

الله جل ذكره الخبرَ عن نفسه بذلك، بلفظ الجماعة؛ للتعظيه.

قريباً من هذا ذكره ابن غلبون والداني والأشموني؛ إلا أن ابن غلبون لهن

والداني ذكرا ذلك ولم يبينا درجته. ولكن عبارتهما هذه هي عبارة الوقف

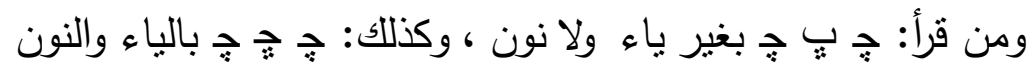

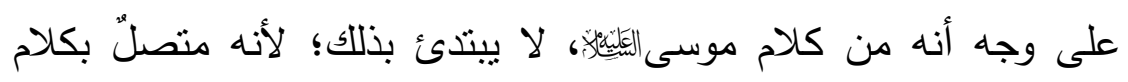
موسى، ومتعلق بما نقدم من إخباره عن

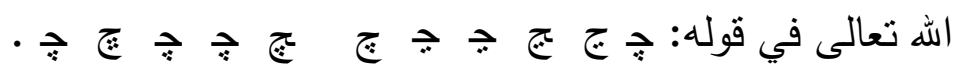


قربياً من هذ ، ذكره ابن غلبون والداني والأشموني ؛ إلا أنهم ذكروا

ذلك على قراءة حذف الياء والنون، ولم يتعرضوا لوجه القراءة الأخرى('). وبما أنه رأس آية؛ فالوقف عليه مستحبٌ. 
الموضع الخامس والعشرون

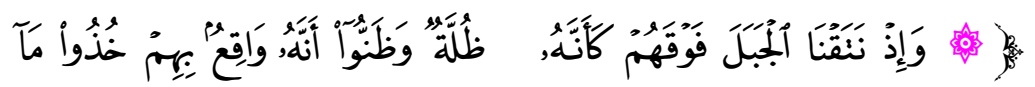

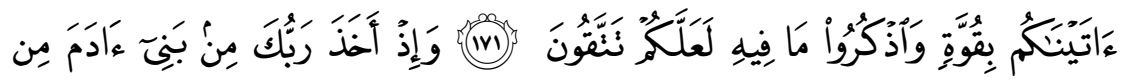

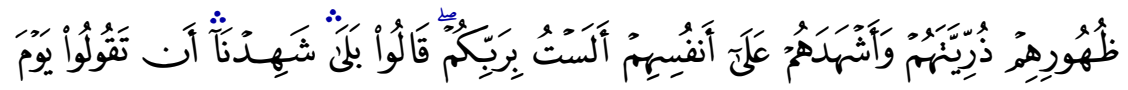

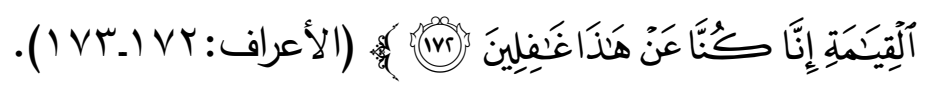
القراع|ت: - (ات

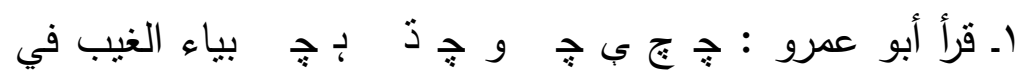

الفعلين -

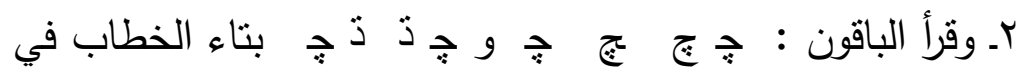

(الفعلين (') (1) (-)

هذا الموضع قد تكلم فيه علماء هذا الفن، وغيرهم من أهل التقسير، من حيث الوقف والابتداء، واعتتوا به، ومن هؤلاء: ابن الأنباري والنحاس والداني والسجاوندي وابن عطية والرازي والقرطبي، وغيرهم. وسأذكر أولاً: حكم الوقف والابتداء على حسب ما ورد في التوجيه، باختصارٍ، ثم أنقل كلامهم بتصرفٍ. فعلى قراءة الغيب ووجه الالتفات من قراءة الخطاب لا يقف على

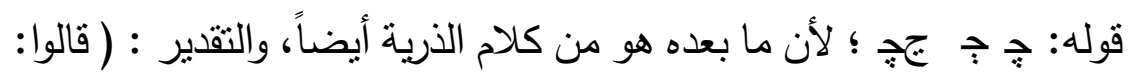
بلى شهدنا كراهة أن يقولوا، أو : لئلا يقولوا...). وعلى الوجه الثاني من قراءة الخطاب باحتمالاته الثلاثة، يكون

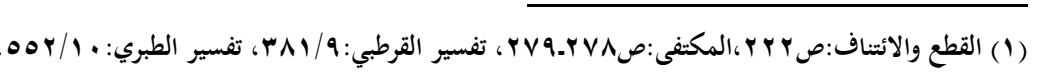




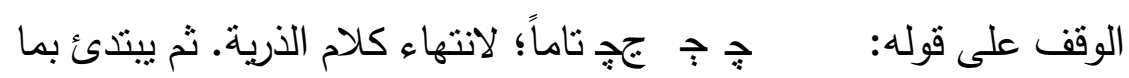

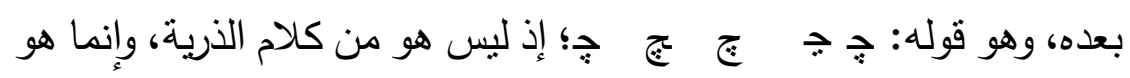
أحد الاحتمالات الثلاثة كما سبق في التوجيه.

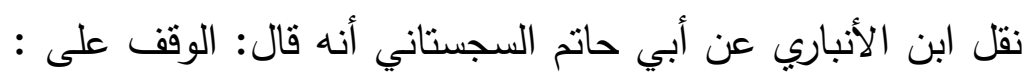

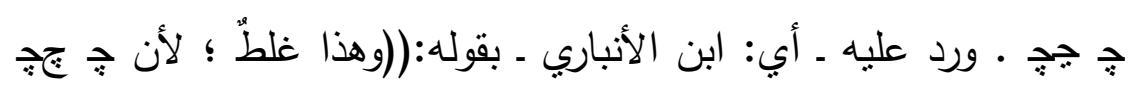

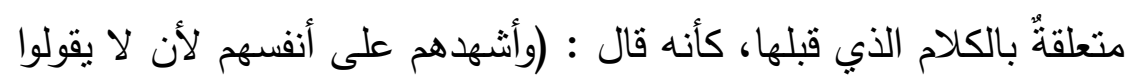

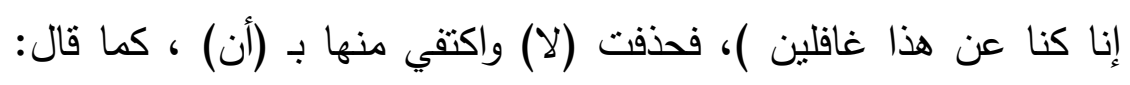

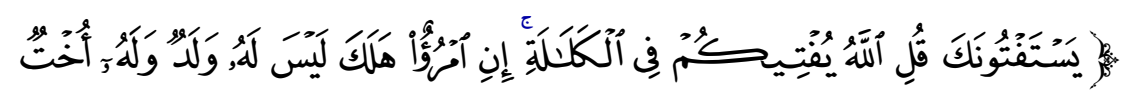

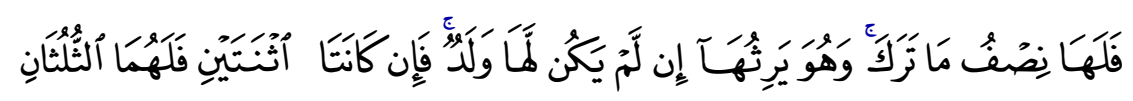

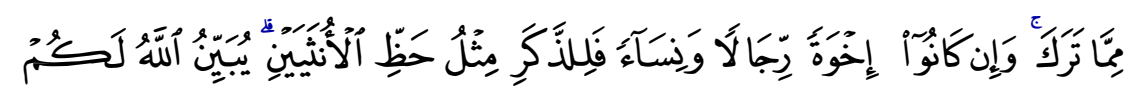

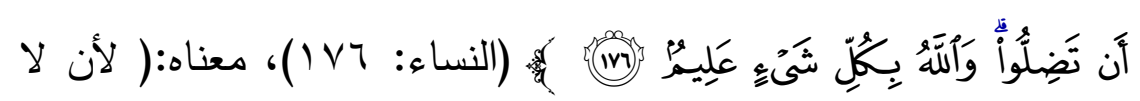
تضلوا )...).

ونقل النحاس الوقف على قوله: جٍ جֶٍ عن الأخفش وأبي حاتم السجستاني وابن مجاهد. ثم قال:(( وفي هذا إثكالٌّ نشرحه ــ إن شاء الله

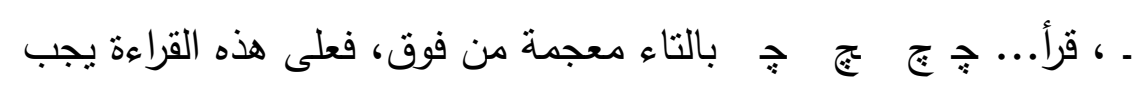

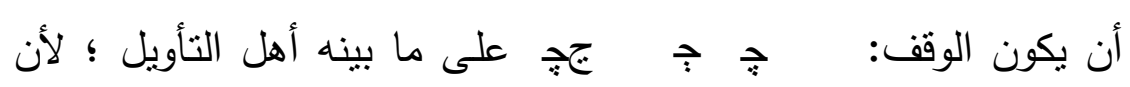

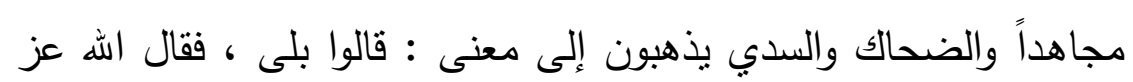

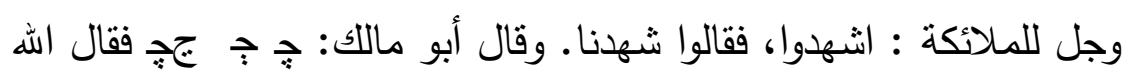
جل وعز شهنا. قال أبو جعفر [ أي: نفسه]: فعلى قول أهل التأويل

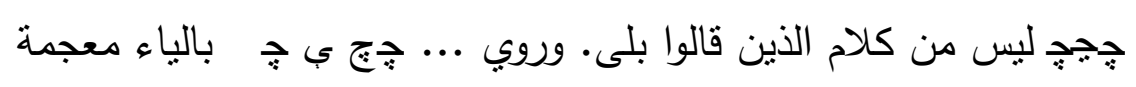


من تحت، وأكثز أهل العربية يقول: التقدير: وأثشهدم على أنفسهم أن يقولوا، أي: كراهة أن يقولوا ، ولئلا يقولوا. والكلام على هذا متصلٌ ،

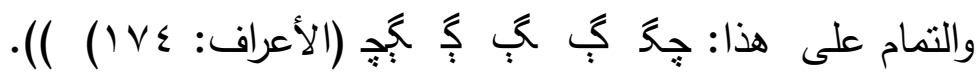

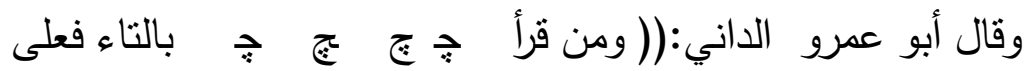

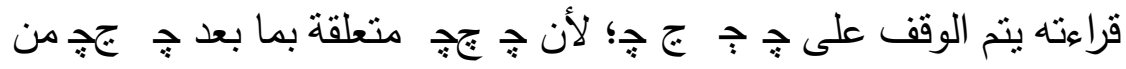

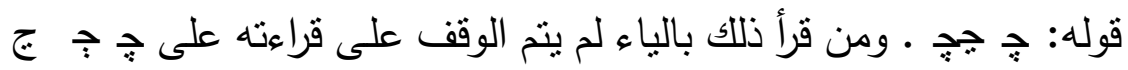

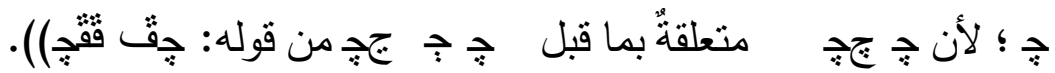

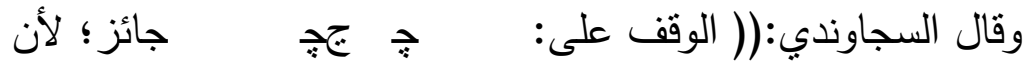

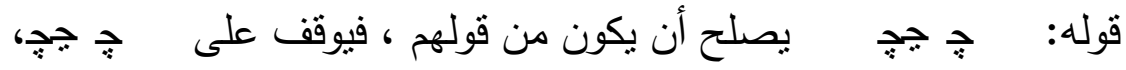

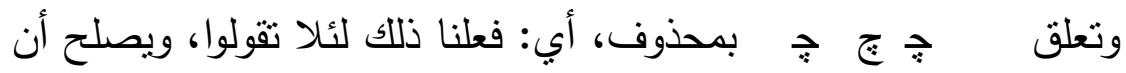
يكون جهجه من قول الملائكة، أي: قيل للملائكة: اشهدوا، فقالوا: شهدنا،

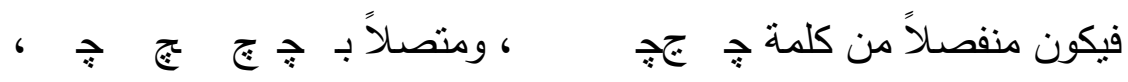

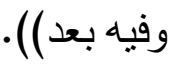

وإن كان جه ليس من كلام الذرية، فذكر ابن عطية والرازي

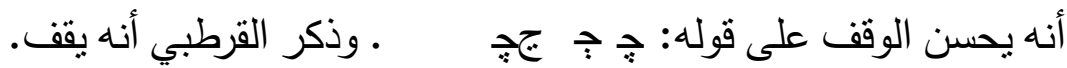

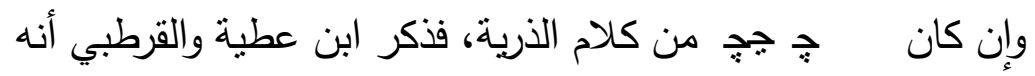

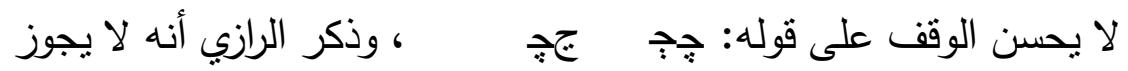

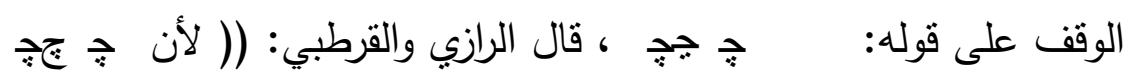

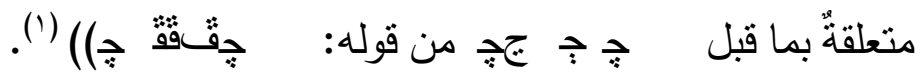




\section{الموضع السادس والعثرون}

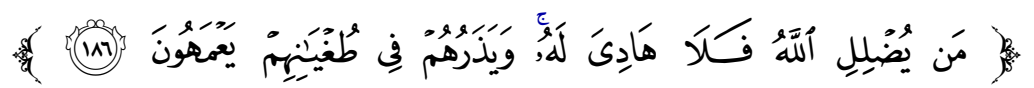

$$
\text { (الأعراف: (القراعات: ) }
$$

اـ قرأ نافع، وابن كثير، وابن عامر، وأبو جعفر :ج بـ ج بالنون

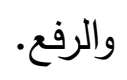

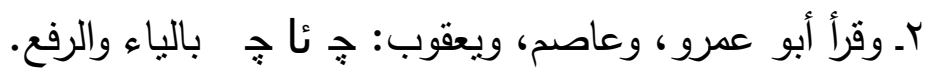

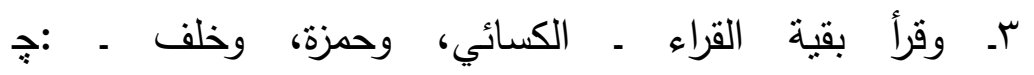

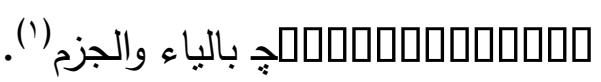

على قراءة الرفع - سواء بالياء أو بالواو - ووجه إسكان الراء لتوالي

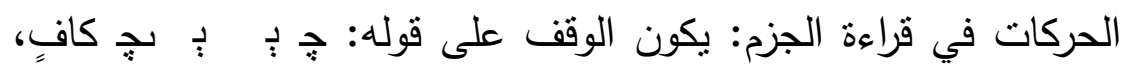
وييتذئ بما بعده؛ لأنه مستأنف ، بتقدير عطف جملة تامة على جملة تامة، والابتداء مع النون أحسن منه مع الياء ؛ من أجل ما في الياء من مشاكلة التعلق باسم الله المتقدم ذكره.

ذكر ذلك ابن غلبون والداني، وقربباً منه ذكره ابن الأنباري؛ إلا أنهم لم يبينوا مرتبة الوقف ـ ويفهم من كلامهم أنه الوقف الكافي. وسماه النحاس : تمام ، والسجاوندي : مطلق، والأنصاري: حسنٌ، والأشموني :كافٍ.

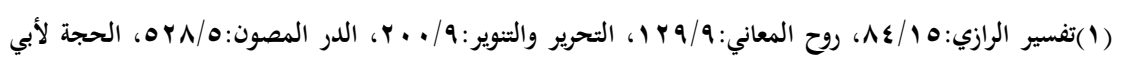

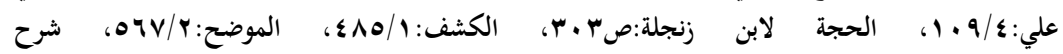

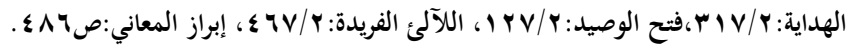


ذكروا هذا على قراءة الرفع، أما على وجه الإسكان لتوالي الحركات

فلا أحداً منهم تكلم في ذللك، لا الداني ولا النحاس ولا غيرها.

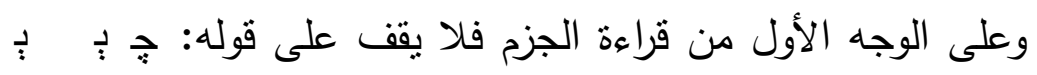

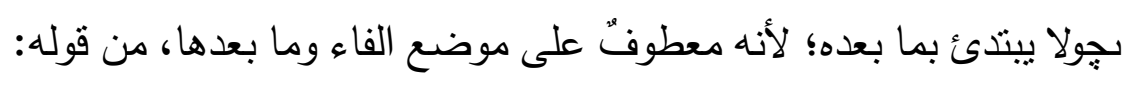

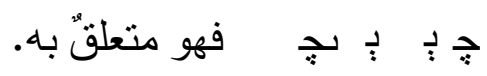

ذكر ذللك ابن الأنباري والنحاس وابن غلبون والداني والسجاوندي

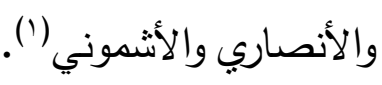

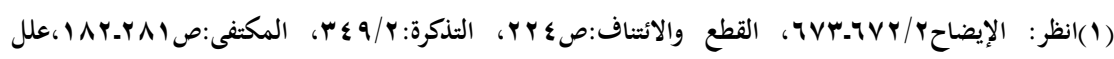

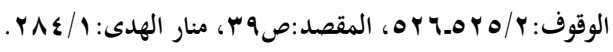




\section{الموضع السابع والعثرون}

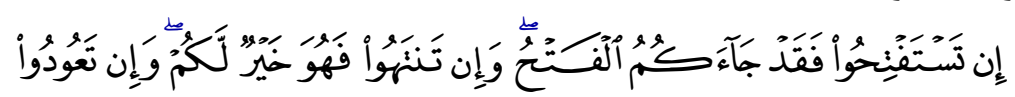

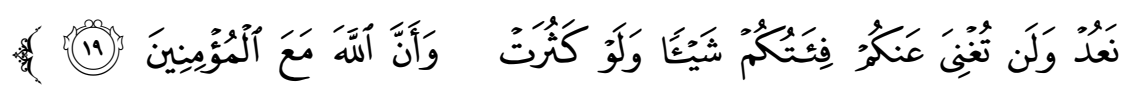

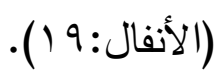

القراع|ت: - (الات:

ا ـ قرأ نافع، وابن عامر ، وحفص عن عاصم، وأبو جعفر : جـ ذّ ذّ جٍ

بفتح الهزة.

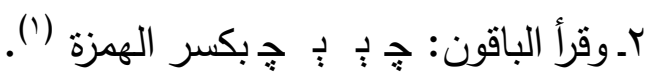

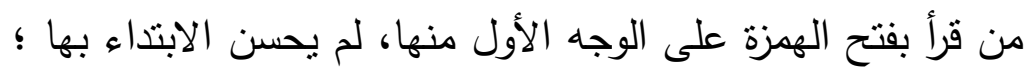

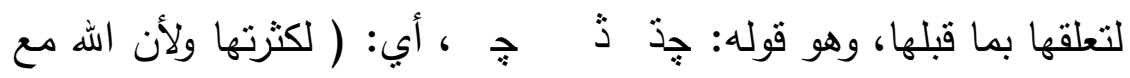
المؤمنين). وقريباً من هذا ذكره ابن الأنباري والنحاس وابن غلبون ولهن والداني

$$
\text { والأنصاري والأشموني. }
$$

وعلى الوجه الثاني من قراءة الفتح يكون الوقف كافٍ؛ لطول الفصل

بين المعطوف والمعطوف عليه، كما في التوجيه. ويقرب منه في حكم الوقف: الوجه الثالث من هذه القراءة؛ لأن ما بعده جملة ابتدائية من مبتدأ وخبر ؛ إلا أنه قد ينقص درجة عن الكافي فيصبر قريباً من الحسن. والله تعالى أعلم.

ومن قرأ بالكسر ، فيحسن الوقف على قوله :جذّ ذأذ والابنداء بها؛ لأنها مستأنفة، غير متعلقة بما قبلها. وهو قول ابن الأنباري وابن غلبون. وهو وقف تام عند النحاس، وكافٍ عند الداني والأنصاري والأشموني، ومطلقٌ عند السجاوندي (r) (r).

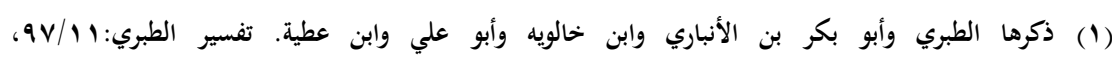

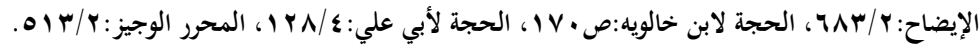

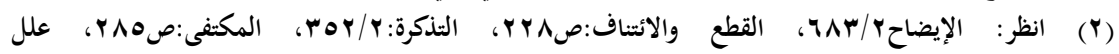

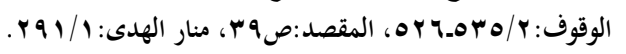




\section{الموضع الثامن والعشرون}

(الأنفال: 990).

القراعات:

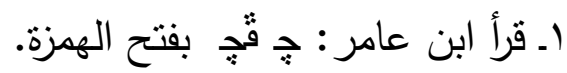

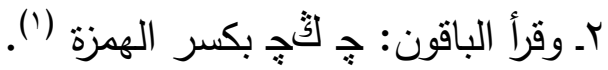

على قراءة الفتح بأوجهها الثلاثة، لا يحسن الوقف على ما قبلها ولا

الابتداء بها؛ لتعلقها بما قبلها، كما سبق في التوجيه. وقريباً من هذا على الوجه الأول، ذكره ابن غلبون والداني والأنصاري والأشموني. وعلى قراءة الفتح يحسن الابتداء بها والوقف على ما قبلها، ويكون كافٍ؛ لاستئنافها، وعدم تعلقها بما قبلها من حيث الإعراب . وهو كافٍ عند الداني، ويعقوب كما ذكر عنه النحاس، ومطلقٌ عند السجاوندي، وحسنٌ عند الأنصاري والأشموني (؟). 


\section{الموضع التاسع والعشرون}

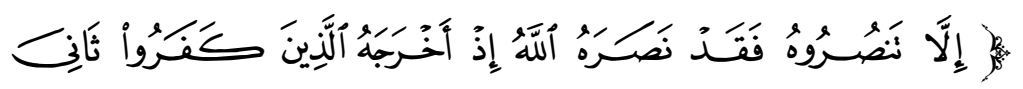

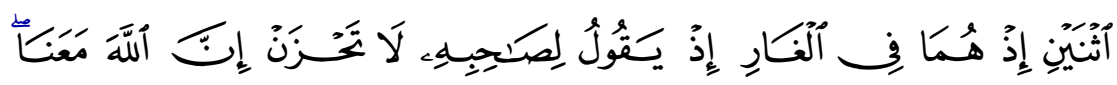

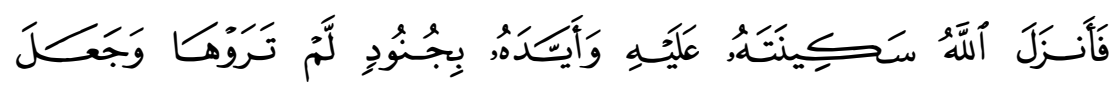

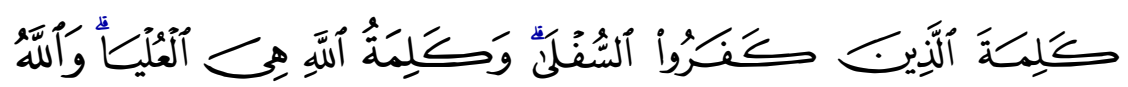

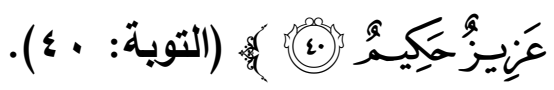

$$
\begin{aligned}
& \text { القراءات: }
\end{aligned}
$$

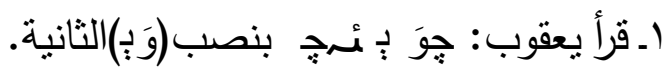

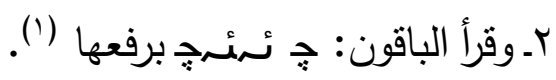

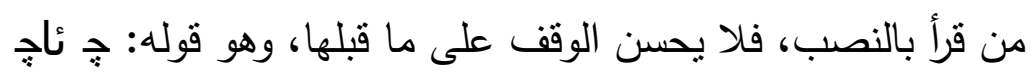

$$
\text { ولا الابتداء بها؛ لأنها }
$$

معطوفة على ما قبلها، وهو قوله: جِبْبِ فلا يفصل بينهما.

$$
\text { قربياً من هذا ذكره ابن غلبون والأنصاري والأشموني. }
$$

ومن قرأ بالرفع فيحسن الوقف على ما قبلها، والابتداء بها؛ لأنها

$$
\text { مستأنفة منقطعة عما قبلها. }
$$

وهو وقف تام عند النحاس والأنصاري والأشموني، وكافٍ عند الداني، ومطلقٌ عند السجاوندي، وذكر ابن الأنباري أنه حسن، ثم تبتدئ بما بعده. وكلامه هذا هو الوقف الكافي (؟).

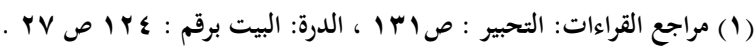

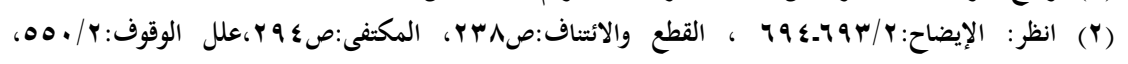

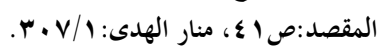




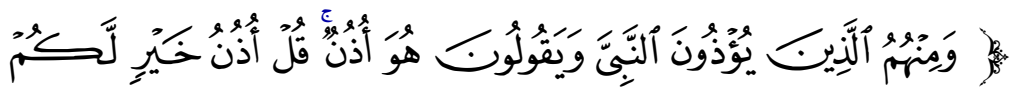

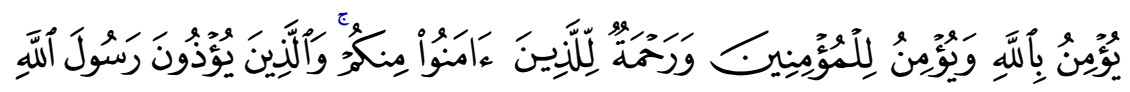

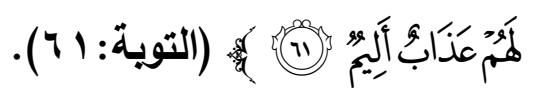

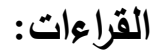

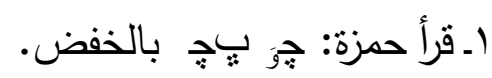

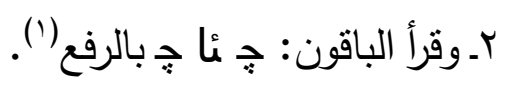

على قراءة الجر ، والوجه الأول والثالث من قراءة الرفع ، لا يحسن

الابتداء بها؛ لأنها معطوفةٌ على ما قبلها كما بيناه في التوجيه.

وعلى الوجه الثاني من قراءة الرفع يحسن الوقف على ما قبلها، وهو

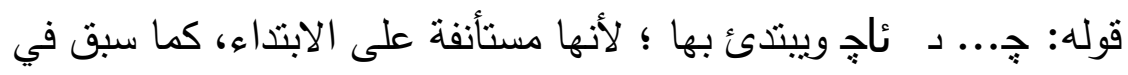

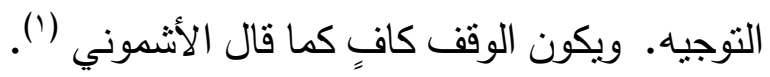




\section{الموضع الحادي والثلاثون}

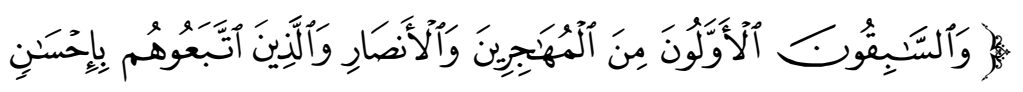

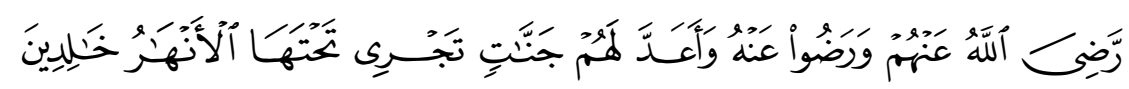

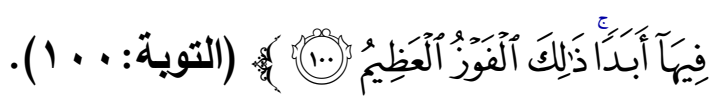

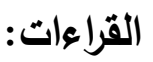

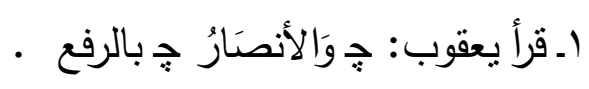

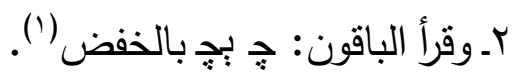

على قراءة الجر ، والوجه الأول من قراءة الرفع ، لا يحسن الوقف هُ لهن على ما قبلها ، وهو قوله :

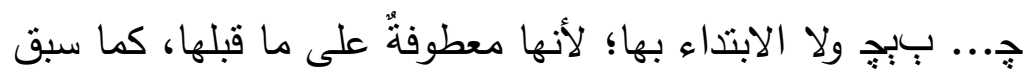

في التوجيه.

وعلى الوجه الثاني من قراءة الرفع يحسن الوقف على ما قبلها،

وبيتذئ بها ؛ لأنها مستأنفة على الابتداء، كما سبق في التوجيه. وبكون الوقف كافٍ • والله تعالى أعلم .

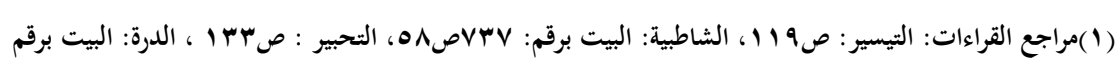

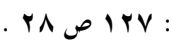




\section{الموضع الثاني والثلاثون}

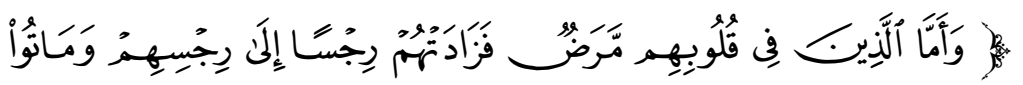

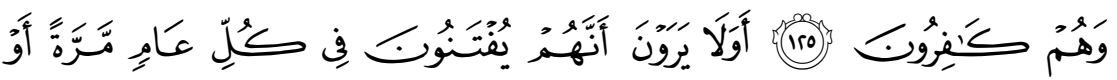

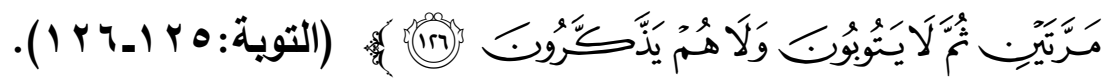

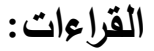

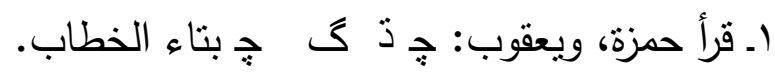

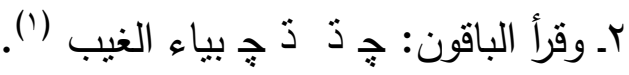

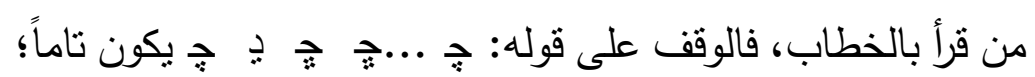

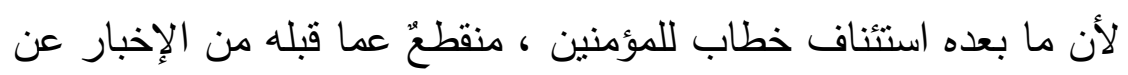

المنافقين، كما سبق في التوجيه. فيحسن الوقف للفصل بينهما.

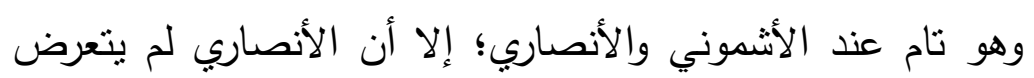

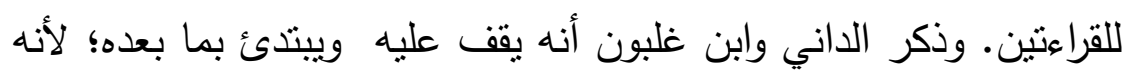
استئناف خطاب، منقطعٌ مما قبله. ولم يبينا درجة الوقف. وعبارتهما هذه

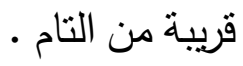

ومن قرأ بالغيب فلا يقف على ما قبله؛ لأن ما بعده راجعٌ إلى الكفار ،

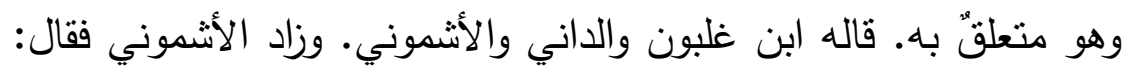

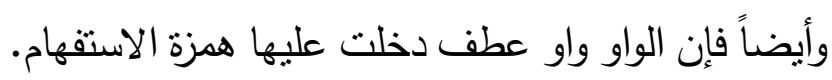

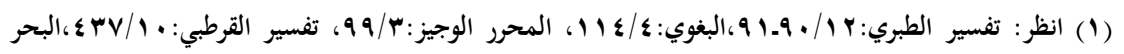

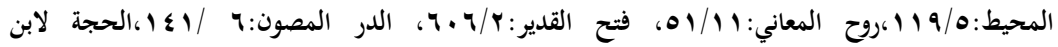

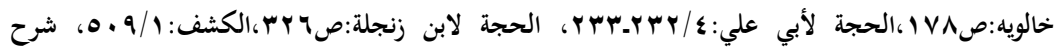

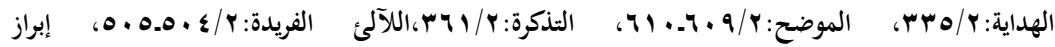

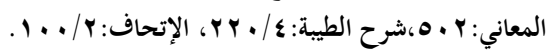


وذكر النحاس أن الوقف عليها غير تام؛ لأن الواو واو عطف دخلت

عليها همزة الاستفهام (').

ولكن يرى الباحث أن الوقف عليه كافٍ ، وإن كانت الواو عاطفة كما

فالوا؛ لأنه استقهام للتقربع والتوبيخ، فيحسن الابتداء به. والواو عاطفة جملة على جملة. وأيضاً يفهم من عبارة النحاس أنه كافٍ غير نام. وبما أنه رأس آية فالوقف عليه مستحبٌ. والله تعالى أعلم. 
الموضع الثالث والثلاثون

مرأِ

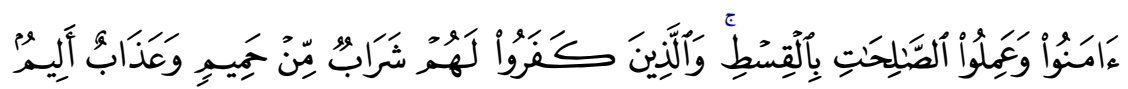

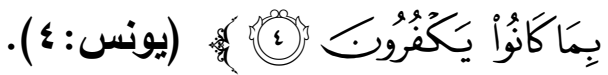

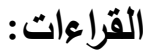

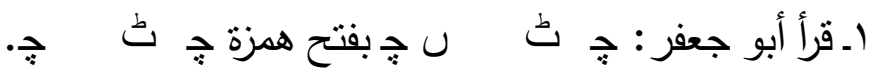

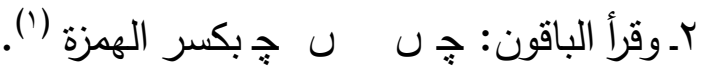

على الوجه الثالث من قراءة الفتح ـ وهو قول الفراء ـ ، لا يحسن

الوقف على قوله : هֶ: جِ ؛ ؛ لتعلق ما بعده بما قبله ، كما بيناه في التوجيه.

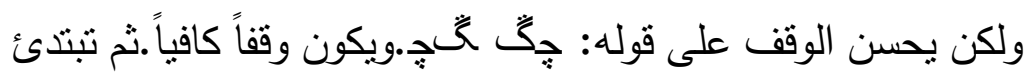

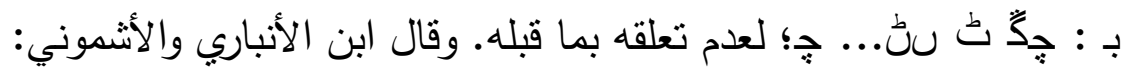

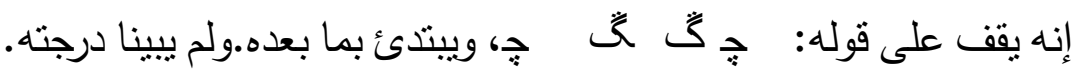

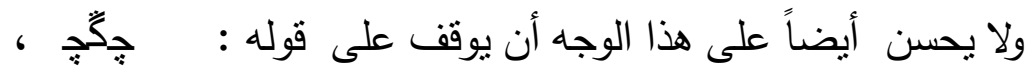

$$
\begin{aligned}
& \text { بل يصله بما بعده ، وهو قوله : } \\
& \text { ج }
\end{aligned}
$$

وعلى بقية الأوجه من قراءة الفتح، يحسن الوقف على قوله : جِّد

ج ، وهو كافٍ عند النحاس والداني والأنصاري. ومطلقٌ عند السجاوندي . وحسنٌ عند الأشموني. وحسنٌ غير تام عند ابن الأنباري.

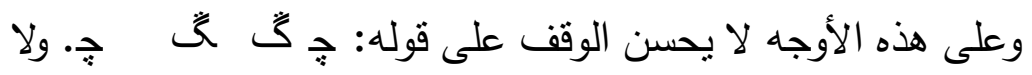




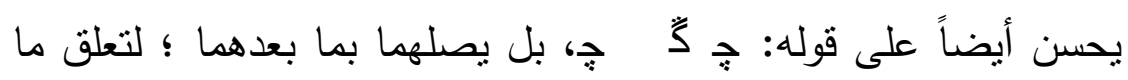
بعدهما بهما، كما سبق في التوجيه.

وعلى قراءة الكسر يحسن الوقف على قوله: جِجٍ جه، ولا يحسن الوقف

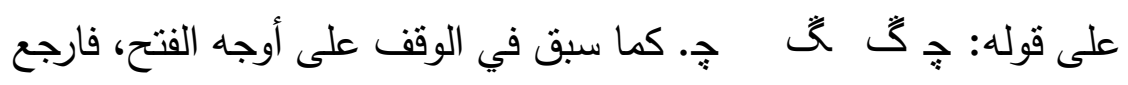
إلبه، فما قيل هناللك يقال هنا.

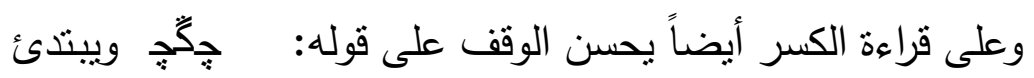
بما بعده ؛ لاستئنافه ، وعدم تعلقه بما قبله. وهو وقف كافٍ عند النحاس والداني ـ ومطلقٌ عند السجاوندي • وحسنٌ عند الأنصاري والأشموني. وذكر ابن الأنباري: أنه يوقف عليه، ويبتدئ بما بعده('). 


\section{الموضع الرابع والثلاثون}

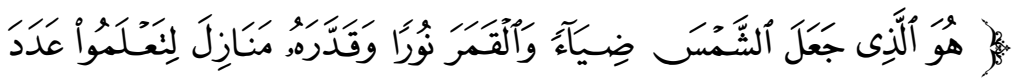

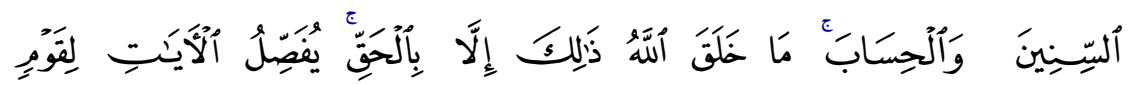

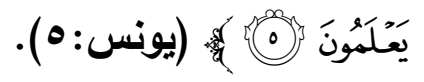

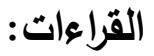

اـ قرأ ابن كثير ، وأبو عمرو، وحفص عن عاصم، ويعقوب: جُئر ج بياء الغيب.

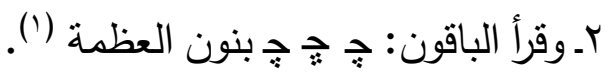

على قراءة الباء، ووجه الالتفات من قراءة النون، لا يحسن الوقف لهان

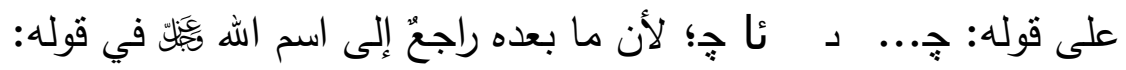

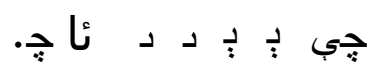

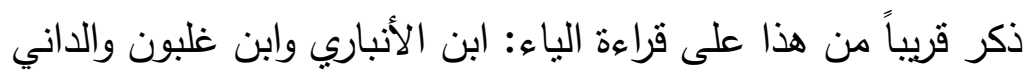
والنحاس والأثموني.

ولكن أرى أنه يحسن الوقف عليه؛ لأن ما بعده هو من عطف الجمل.

واستغني عن العطف؛ لثدة الملابسة بالجملة السابقة . وعلى وجه الاستئناف من قراءة النون، يحسن الوقف على قوله: جه...

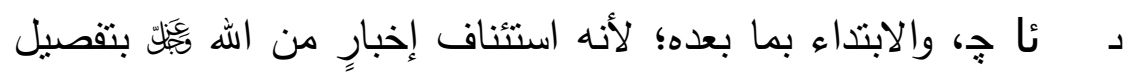

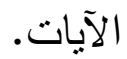

ذكر قريباً من هذا: ابن الأنباري وابن غلبون. وهذا الوقف: حسنٌ عند النحاس، وكافٍ عند الداني والأشموني، ومطلقُ عند السجاوندي.

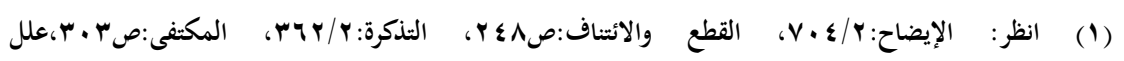

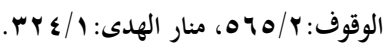




\section{الموضع الخامس وإلثلاثون}

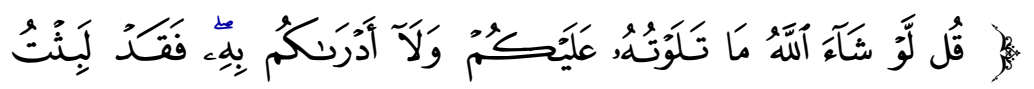

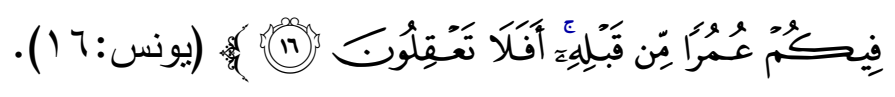

القراع|ت:

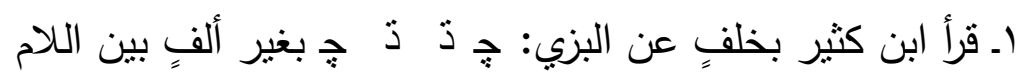

والهمزة.

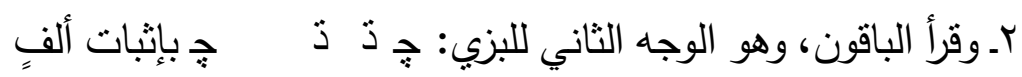

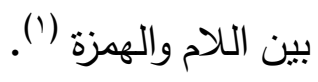

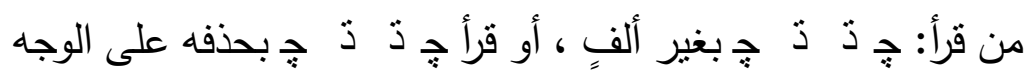

الأول ، لا يحسن الابتداء به ؛ لأنه متعلقُ بما قبله، كما سبق في التوجيه.

$$
\text { ذكر قريباً من هذا ابن غلبون والداني والأشموني. }
$$

ومن قرأ: جر ذ ذ ذ جُ بحذف الألف على الوجه الثاني، حسن الابتداء

به؛ لأنه إخبارٌ بإيقاع الدراية بالقرآن من الله لهم، فهو منقطعٌ من النفي

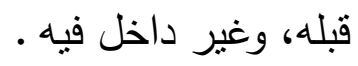

ذكر قريباً من هذا ابن غلبون والداني والأشموني. وجعله الأشموني

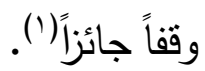


الموضع السادس والثثلاثون

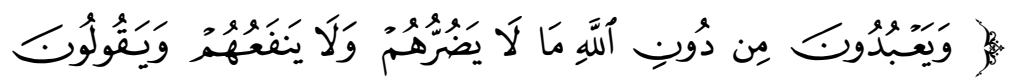

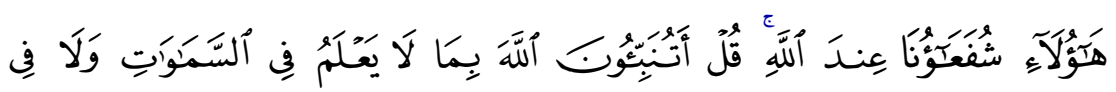

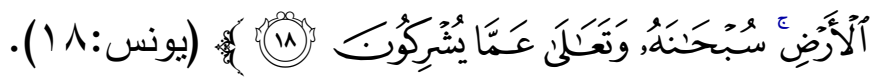

القراء|ت: - (ات

ـ ـرأ حمزة، والكسائي، وخلف: جو و جـ بتاء الخطاب.

rــوقرأ الباقون: جهوو جه بياء الغيب (').

على قراءة الخطاب، والوجه الأول من قراءة الغيب، لا يكون الوقف

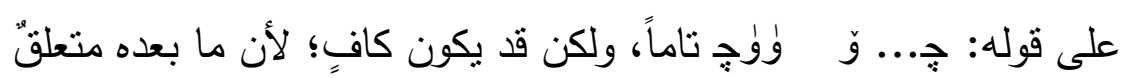
بما قبله، كم سبق في التوجيه. وعلى الوجه الثاني من قراءة الغيب يكون الوقف على قوله: جٍ... وّ وُؤج تاماً؛ لأنه استئناف تتزيه من الله تعالى ، غير داخل في المقول قبله. والله تعالى أعلم. 
الموضع السابع والثلاثون

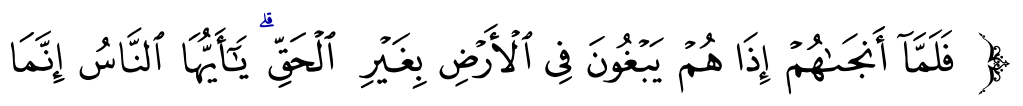

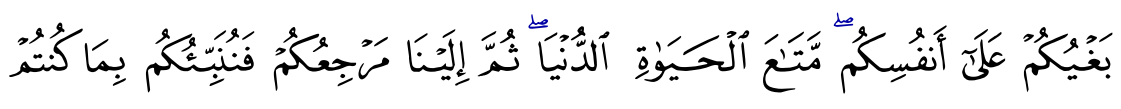

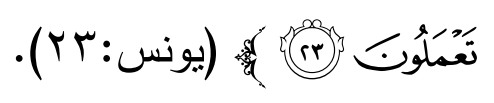

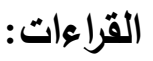

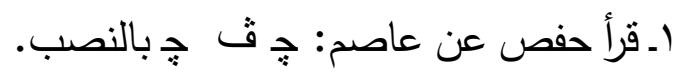

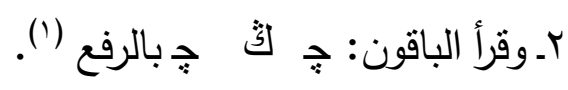

في الوجهين الأولين من قراءة النصب، ذكر ابن غلبون والداني: أنه

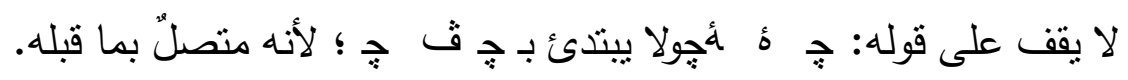
كما بيناه في التوجيه. بينما ذهب الأنصاري والأشموني أنه على الوجه الثاني

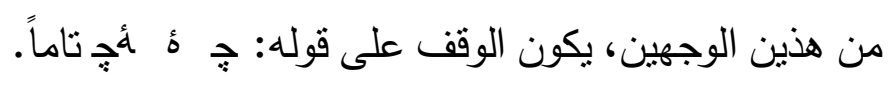
والراجح مما سبق، التوسط، وهو أن يكون الوقف على هذين

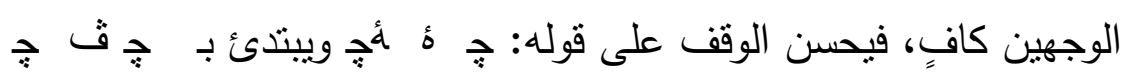
؛ لأنه متعلقُ بمحذوف من حيث الإعراب، كما سبق في التوجيه، وأيضاً هو استئناف، كما قال الثوكاني والآلوسي. فقال الثوكاني على الوجه الأول منهما: (( ويكون في موضع المصدر المؤكد ، كأنه قيل : 
تتمتعون متاع الحياة الدنيا ، ويكون المصدر مع الفعل المقدر

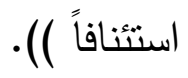

وقال الآلوسي على الوجه الأول منهما أيضاً: ((نصب على أنه

مصدر مؤكد لفعل مقدر بطريق

الاستئناف، أي: تتمتعون متاع الحياة الدنيا)).

وقال ـ أب: الآلوسي - في الوجه الثاني: (( وقيل : العامل فيه،

فعل مدلول عليه بالمصدر ، أي:

تبغون لأجل متاع الحياة الدنيا، على أن الجملة مستأنفة)).

وعلى بقية الأوجه من قراءة النصب، والوجه الثاني من قراءة الرفع،

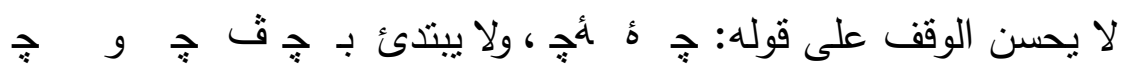

كث ج؛ لأنها متعلقة بما قبلها، كما بيناه في

التوجيه.

وعلى الوجه الأول من قراءة الرفع يحسن الوقف على:جٍ هُ هُجه،

$$
\text { والابتداء بـ جه }
$$

إلا أن الوقف على هذا الوجه أحسن مما هو على الوجهين الأولين

من قراءة النصب.

والوقف على هذا الوجه : كافٍ عند الداني، ومطلقٌ عند

السجاوندي، ونامُ عند الأنصاري والأشموني. وذكر ابن الأنباري: أنه

يحسن الوقف عليه. وذكر ابن غلبون: جواز الابتداء به(').

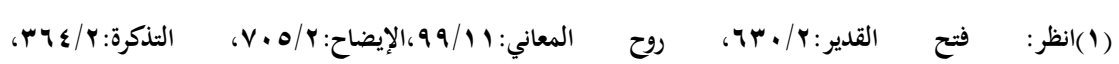

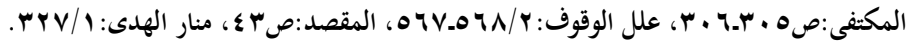




\section{الموضع الثامن والثثلاثون}

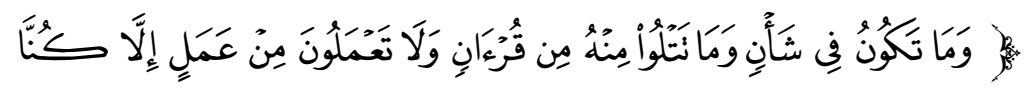

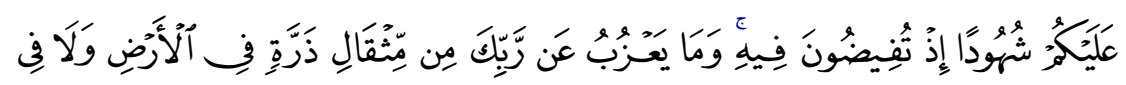

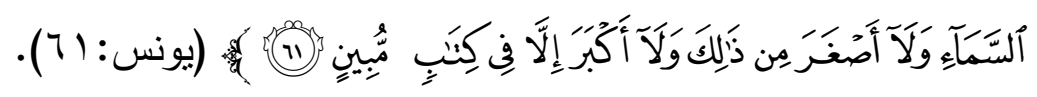

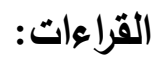

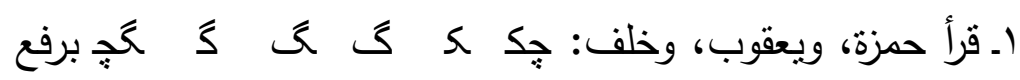

9 كلمتي: جִجִ

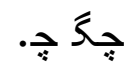

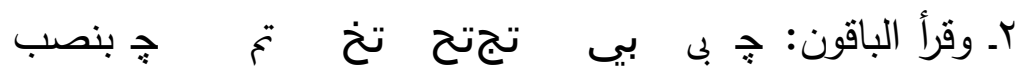

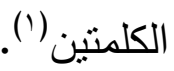

على الوجهين الأولين من القراءثين ـ اختيار الجمهور ـ لا يحسن

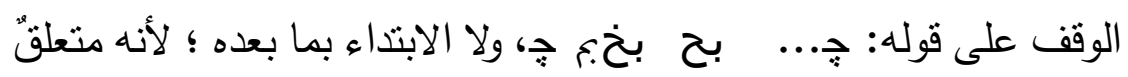
بما قبله، كما بيناه في التوجيه. ثم إن الاستثناء في قوله: جه تى تئنج

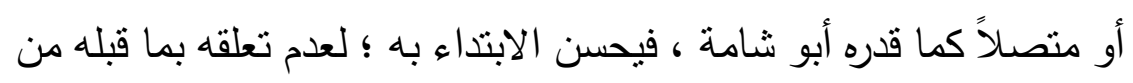
حيث الإعراب. والله تعالى أعلم. وعلى الوجهين الأخيرين من القراعتين ـ اختيار الزمخشري ـ يحسن

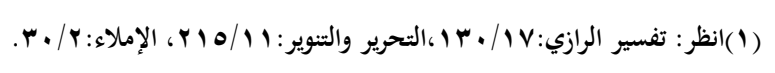




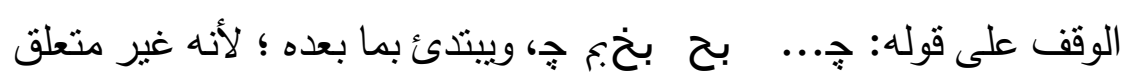

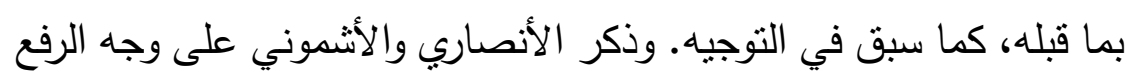
على الابتداء: أن الوقف كافٍ (').

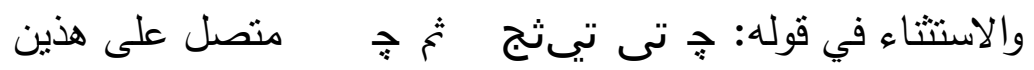

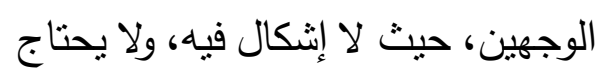

أيضاً إلى تقدير ، لذا لا يحسن الوقف على ما قبله ، ولا الابنداء بهـ ؛

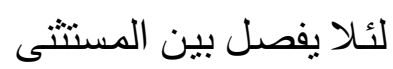
والمستثىى منه. والله تعالى أعلم. 


\section{الموضع الأريعون}

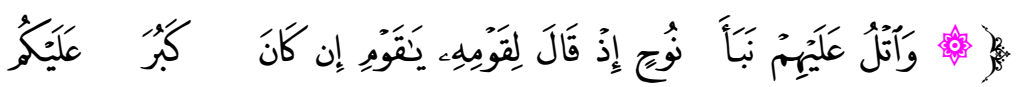

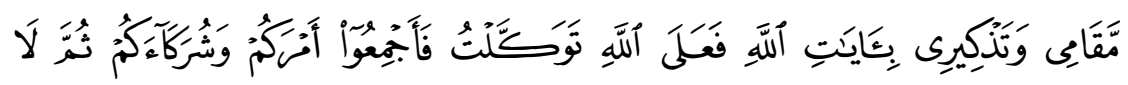

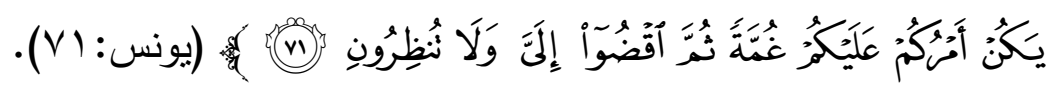
القراءات:

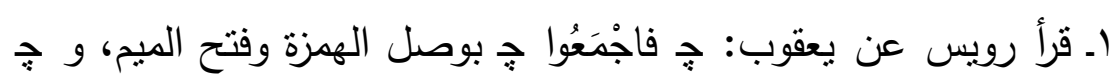
كيج بالرفع.

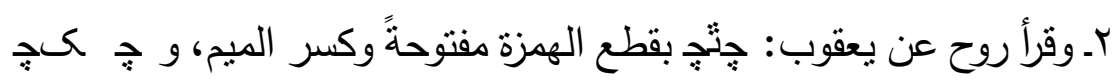
بالرفع.

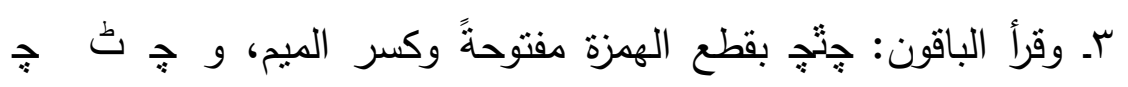
بالنصب ('). على الوجه الثاني من قراءة الرفع، والوجه الأول من قراءة النصب،

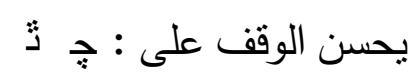
ثل جه ويكون كافٍ ، و ويبتدئ بما بعده ؛ لأن ما بعده على وجه الرفع جملة ابتدائية خبرها

محذوف، وعلى وجه النصب مفعولٌ لفعلٍ مضمر محذوف ، كما بينا ذلك في التوجيه.

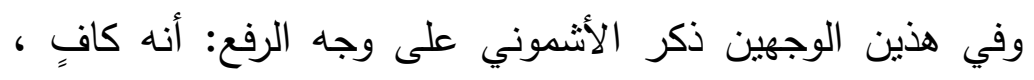
وعلى وجه النصب : لا يقف. وقال النحاس على وجه النصب: لا يتم القطع على ما قبل جٍ ث لان

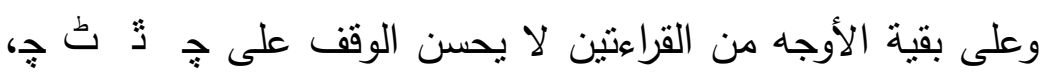
ولا يبتدئ بما بعده؛ لتعلقه بما قبله، كما سبق في التوجيه. واله تعالى أعلم 


\section{الموضع الحادي والأريعون}

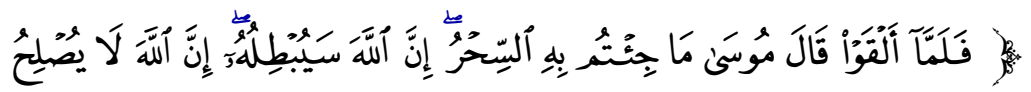

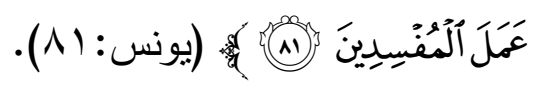

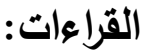

اـ قرأ أبو عمرو، وأبو جعفر: جأَألسحر جه بزيادة همزة استقهام قبل

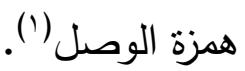

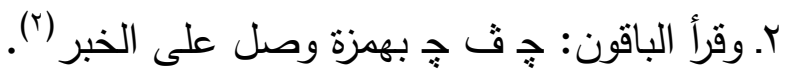

على الوجه الأول من كلا القراءتين لا يحسن الوقف على قوله:ج

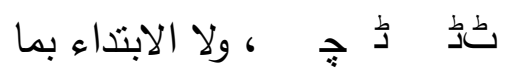

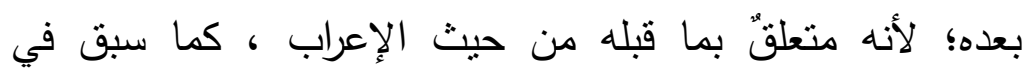

التوجيه ـ وقريباً من هذا ، ذكره ابن

غلبون والداني والأثموني، والسجاوندي على وجه قراءة الخبر .

وعلى بقية الأوجه من كلا القراءتين يحسن الوقف على قوله: جر ضدُ

لُ ج ويكون كافٍ ، وييتدئ بما بعده؛ لأنه مستأنف غير متعلق بما قبله

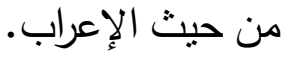

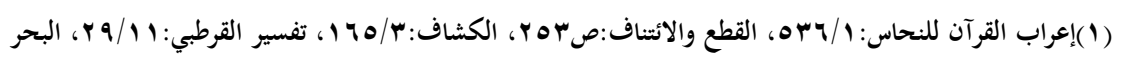

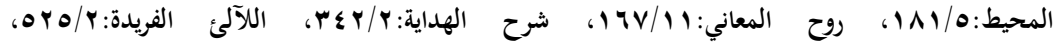

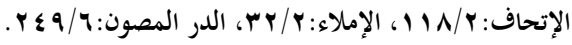

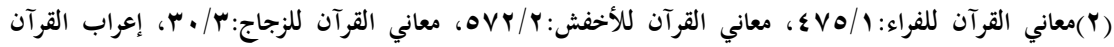

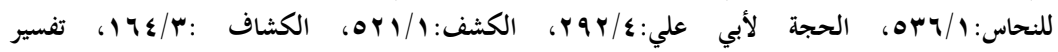

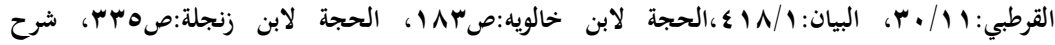

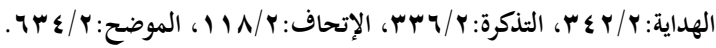




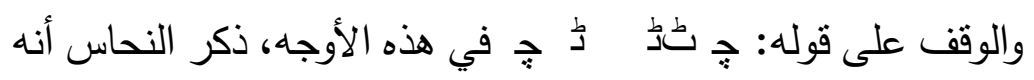

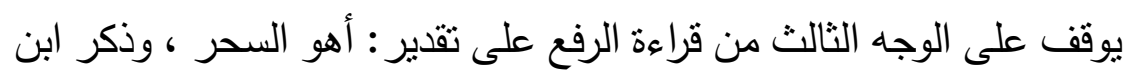

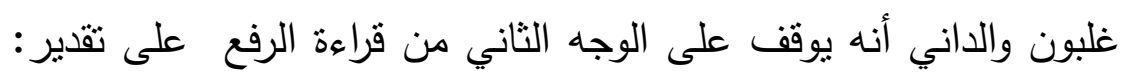

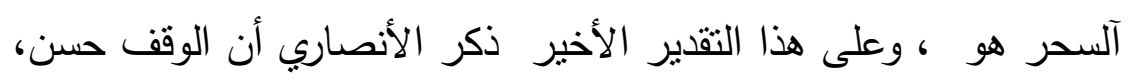

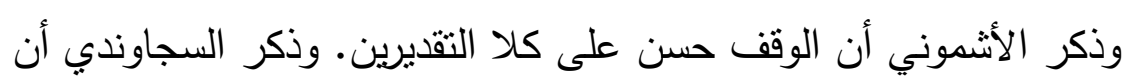

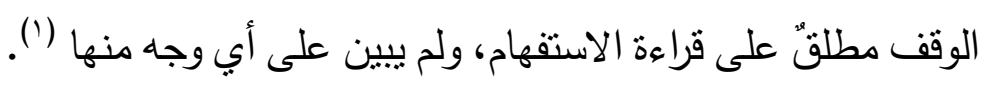




\section{الموضع الثاني والأريعون}

若

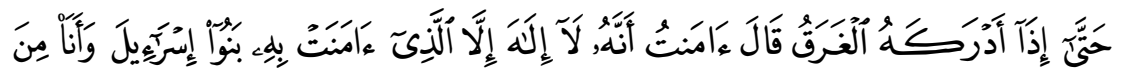

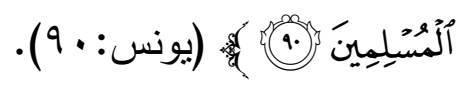

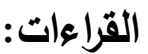

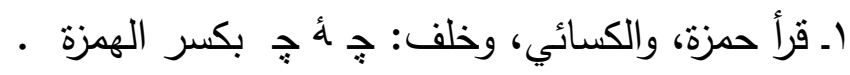

ז. وقرأ الباقون: هُ قُ جه بقتح الهمزة (').

على الوجه الأول من قراءة الكسر يحسن الوقف على قوله: هُ...

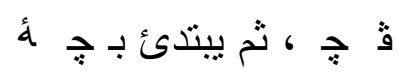

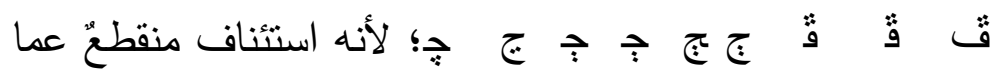

ذكر قريباً من هذا ابن الأنباري وابن غلبون والداني ، وجعله

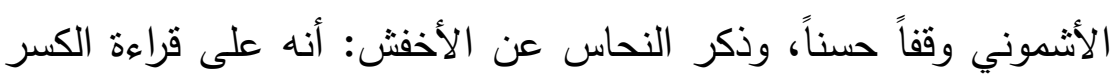

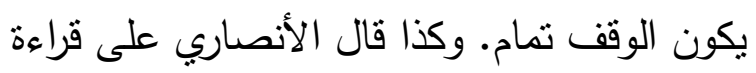

الكسر: إنه وقف حسن. ولعلهم يقصدون بالكسر إن جعلت على وجه الاستئناف. واله أعلم .

ويقرب من هذا الوجه من حيث الوقف: وجه إضمار القول ، 
فيحسن الابتداء به؛ لأنه يشبه الاستئناف، فهو متعلقُ بمحذوف؛ إلا أنه من حيث الوقف أقل حسناً من الاستئناف.

وقد مرت مواضع فيها إضمار القول، وكان مذهب الأنصاري

والأشموني أن الوقف على ما قبلها يكون حسناً، وييتدئ بما بعده، كما

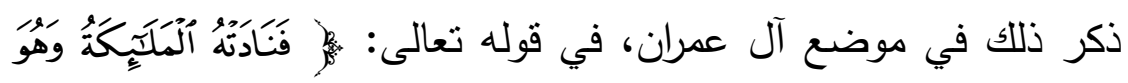

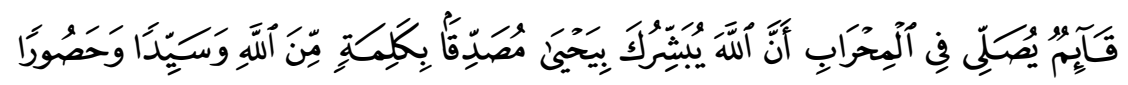

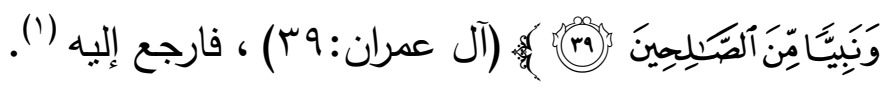
وعلى قراءة الفتح وبقية أوجه الكسر، لا يحسن الوقف على قوله: جُ.. قُ ج ، ولا الابتذاء به؛ لأنه متعلقٌ بما قبله، كما سبق في التوجيه. وذكر قريباً من هذا على بعض الأوجه ابن الأنباري وابن غلبون والداني والأنصاري والأشموني (؟). 


\section{الموضع الثالث والأربعون}

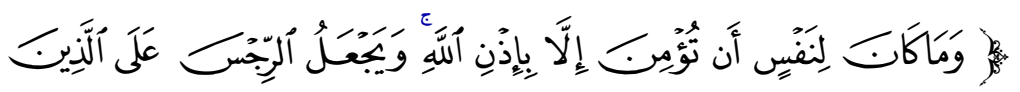

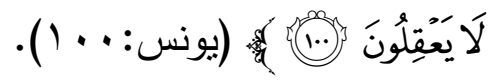

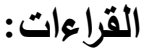

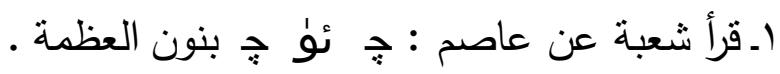

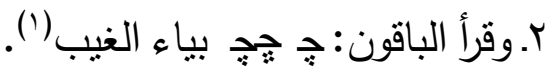

على الوجه الأول من قراءة النون ذكر الداني أن الوقف على قوله:

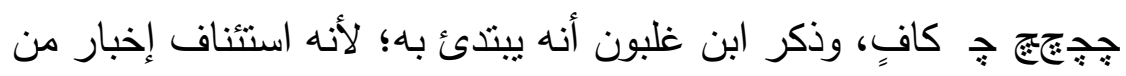
الله تعالى بلفظ الجماعة؛ للتفخيم.

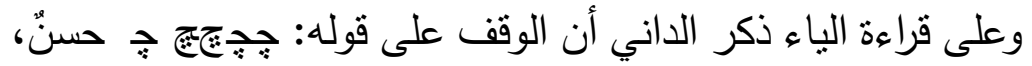

وذكر ابن غلبون كراهة الابتداء بما بعده؛ لأنه متعلقُ باسم الله الذي قبله (1). والوجه الثاني من قراءة النون يكون حكمه في الوقف كقراءة الياء، حيث لا فرق بينهما؛ وإنما هو التفات، كما سبق في التوجيه. واله الموفق لل الصواب والهادي إلى سبيل الرشاد . 


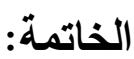

$$
\text { نتائج البحث: }
$$

اـ لعلم القراءات فضله العظيم، وأثزره الكبير في سائر العلوم، ومنها علم الوقف والابتداء، فبين العلمين ارتباطُّوثيق وعلاقة حميمة. r. لعلماء القرآن وتفسيره عناية بالغة بتوجيه القراءات، والاحتجاج لها من حيث المعنى والتفسير ، ومن حيث اللغة والإعراب.

rـ ثم إن منهح من خصه بالتأليف، كأبي علي الفارسي وأبي الفتح بن جني ومكي والمهدوي، وغيرهم. ومنهم من أدرجه ضمن كتبه، كالفراء والأخفش والنحاس والزجاج والطبري وابن عطية والقرطبي وأبي حيان،

$$
\text { وغيرهم. }
$$

عـ بيان أثز القراءات العشر على الوقف والابتداء ، وأن الوقف والابتداء

$$
\text { يتغير حسب القراءة المتلوة وبحسب أوجهها. }
$$

والله أعلم، وصلى الله على نبينا محمد وآله وصحبه أجمعين. 


\section{فهرست المراجع والمصادر}

ـ القرآن الكريم. برواية حفص عن عاصم، مصحف المدينة المنورة، المملكة العربية السعودية.

ا. إبراز المعاني من حرز الأماني في القراءات السبع،لأبي شامة عبد الرحمن بن إسماعيل المقسي(ت 70 (7ه)، تحقيق: إبراهيم عطوة

$$
\text { عوض، دار الكتب العلمية. }
$$

r. إتحاف فضلاء البشر في القراءات الأبع عشر،لأحمد بن عبد الغني الدمياطي(ت VIII Vه)، تحقيق: د/ عبد الكريم شعبان محمد

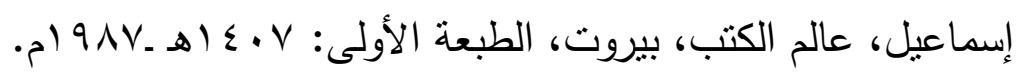
r. الإتقان في علوم القرآن، لجالال الدين السيوطي(ت ا (9ه)، تحقيق: مركز الدراسات القرآنية، مجمع الملك فهد لطباعة المصحف

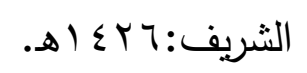

ع. الأحرف السبعة والقراءات وما أثثر حولها من شبهات، للاكتور شعبان محمدإسماعيل، مطبوعات نادي مكة الثقافي

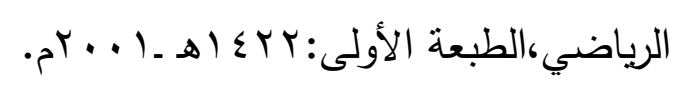

ه. : : أحكام قراءة القرآن الكريم، لمحمود بن خليل الحصري (ت ( • (اهـ )، تحقيق: محمد طلحة منيار ، المكتبة المكية، ودار

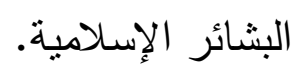

7. إرواء الغليل في تخريج أحاديث منار السبيل، لمحمد ناصر الدين 
الألباني، المكتب الإسلاهي، بيروت، الطبعة الثانية: 0. ؛ـ اهـ

$$
\text { . }) 910
$$

V. الإصابة في تمييز الصحابة، لشهاب الدين أبي الفضل أحمد بن

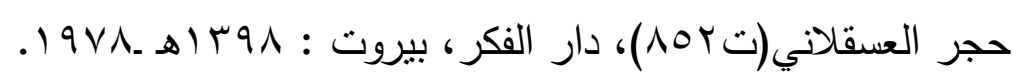

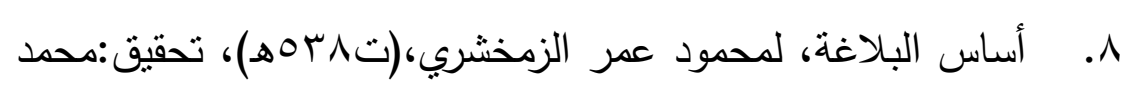
باسل عيون السود ، دار الكتب العلمية، بيروت، الطبعة الأولى :

$$
\text { . } 1991 \text {. ه } 1519
$$

9 9. إعراب القراءات السبع وعلللها، لحسين بن عبد الله بن خالويه(ت • VIهـ)، تحقيق:د/عبد الرحمن العثيمين، دار الخانجي، القاهرة،الطبعة الأولى:ب إع اهـ ـr ب9 (م. • 1. إعراب القرآن ، لأبي جعفر أحمد بن محمد النحاس(یبسه)،

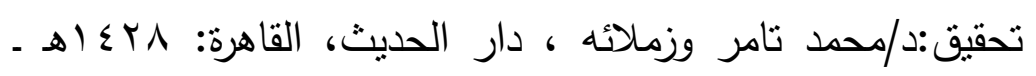

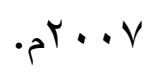

11. الأعلام( قاموس تراجم لأشهر الرجال والنساء من العرب والمستعربين والمستشرقين)، لخير الدين الزركلي(ت 9 ب (هـ)، دار العلم للملايين، بيروت، الطبعة الخامسة عشر : r . . rم. rا. الإقناع في القراءات السبع، لأحمد بن علي(ابن الباذش) ( • عهـ)، تحقيق:د/ عبد المجيد قطامش، من مطبوعات مركز البحث العلمي

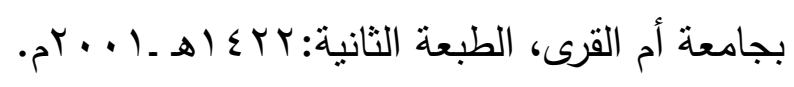


سا. إملاء ما من به الرحمن من وجوه الإعراب والقراءات في جميع القرآن، لعبد الله بن أبي عبد الله العكبري (ت7 آآه)، تحقيق: إبراهيم عطوة عوض، دارالحديث، القاهرة.

ع ا. ـ إنباه الرواة على أنباه النحاة، لجمال الدين أبي الحسين علي بن يوسف القفطي(ت7٪ 7هـ)،تحقيق: محمد أبو الفضل إبراهيم، دار الفكر العربي، القاهرة، ومؤسسة الكتب الثقافية، بيروت، الطبعة

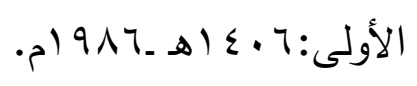
1. الأنساب، لأبي سعد عبد الكربم بن محمد السمعاني(ت ب7هـ)، تحقيق: عبد الله عمر البارودي، دار الجنان،بيروت، الطبعة

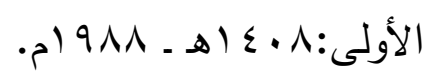

ا1 ا. إيضاح الوقف والابتداء في كتاب اله عز وجل، لأبي بكر بن محمد بن القاسم الأنباري(تمشץهـ)، تحقيق:محي الدين عبد الر حمن رمضان، مطبوعات مجمع اللغة العربية، بدمشق: •وبا اهـ

$$
\text { . }) 9 \times 1 .
$$

V V البحر المحيط، لأبي حيان محمد بن يوسف الغرناطي الأندلسي

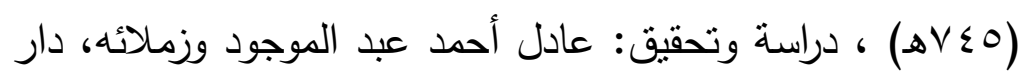
الكتب العلمية، بيروت، الطبعة الأولى:با إ اهـ ــ99 ام. 
9 1. البرهان في علوم القرآن، لبدر الدين محمد بن عبد الها الزركثي(؟ Y هـ)، تحقيق: محمد أبو الفضل إبراهيم، مكتبة دار

التراث، القاهرة.

•r. بغية الوغاة في طبقات اللغويين والنحاة، للحافظ جلال الدين السيوطي(ت الواهـ)، تحقيق: محمد أبو الفضل إبراهيم، المكتبة العصرية، بيروت.

ا r. البلغة في تراجم أئمة النحو واللغة، لمجد الدين محمد بن يعقوب

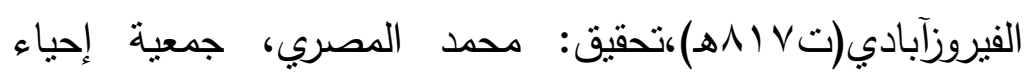
التزاث الإسلامي، الكويت، الطبعة الأولى: V. • أهـ.

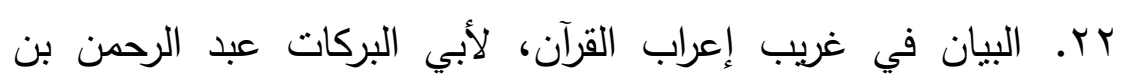

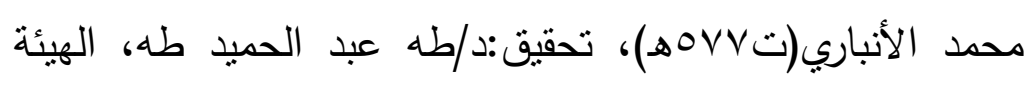

$$
\text { المصرية العامة للكتاب: . .. أهـ ـ (919 ام. }
$$

rr. تاج العروس من جواهر القاموس، للسيد محمد مرتضى

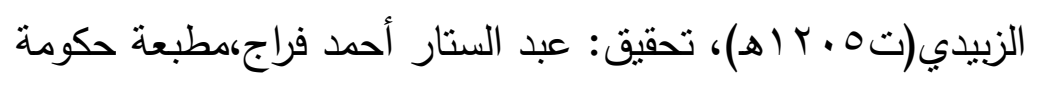

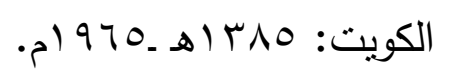

צ r. تحبير التيسير في قراءات الأئمة العشرة، لمحدد بن محمد بن محمد الجزري(تrr/هـ)، تحقيق: جمال الدين محمد شرف، دار

$$
\text { الصحابة للتراث، طنطا: ع ـ . ب بم. }
$$


مr. التحرير والتتوير، للثيخ محمد الطاهر بن عاشور (ت بوبا(ه)، الدار التونسية للنشر ، تونس: عـ9 ام. דr. تذكرة الحفاظ، لشمس الدين محمد بن أحمد الذهبي(ت ع Vه)، دار

$$
\text { إحياء التراث العربي، بيروت. }
$$

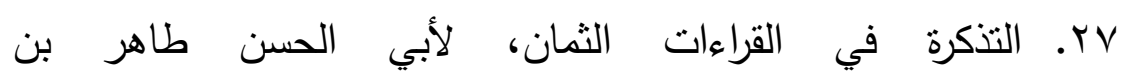
غلبون(ت99 وه)، دراسة وتحقيق:د/ أيمن رشدي سويد، من مطبوعات الجماعة الخيرية لتحفيظ القرآن الكريم بجدة، الطبعة

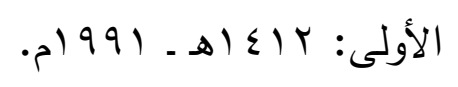

^r. تفسير البغوي( معالم التتزيل)، لأبي محمد الحسين بن مسعود البغوي(ت7 (0هـ)،تحقيق:محمد عبد الله النمر وزملائه، دار طيبة

$$
\text { للنشر والتوزيع، الرياض: } 9 \text { ، ـ (هـ. }
$$

وץ. تفسير الرازي( مفاتيح الغيب ـ التفسير الكبير)، لفخر الدين محمد الرازي(ت7 • جه)، دار الفكر للطباعة والنشر، بيروت، الطبعة

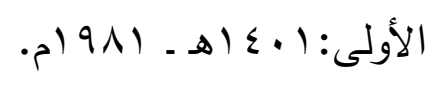

• ז. تفسير الطبري( جامع البيان عن تأويل آي القرآن)، لأبي جعفر محمد بن جرير الطبري(ت •(اسه)، تحقيق: د/عبد الله بن عبد المحسن التركي، دار هجر للطباعة والنشر والتوزيع. 
اس. تقسير القرطبي(الجامع لأحكام القرآن والمبين لما تضمنه من السنة وآي القرآن )، لأبي عبد الله القرطبي (ت اVITه)، تحقيق: د/عبد الله بن عبد المحسن التركي، مؤسسة الرسالة، الطبعة

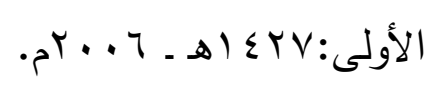

rr. تفسير القرآن العظيم، لأبي الفداء إسماعيل بن عمر بن كثير (ت عV Vه )، تحقيق: مصطفى السيد محمد وزملائه، مؤسسة

$$
\text { قرطبة، جيزة، الطبعة الأولى: ابك اهـ ـ ... . بم. }
$$

بس. التمهيد في علم التجويد، لمحمد بن محمد بن محمد الجزري(تبr/ه)، تحقيق: د/ علي حسين البواب، مكتبة المعارف، الرياض، الطبعة الأولى: 0 . ؛ (هـ ـ1919 ام. ع ז. تتبيه الغافلين وإرشاد الجاهلين، للإمام علي بن محمد الصفاقسي. هب. توجيه مشكل القراءات العشرية الفرشية لغة وتفسيراً وإعراباً، للاكتور عبد العزيز بن علي الحربي، دار ابن حزم، الرياض، الطبعة

$$
\text { الأولى: ع \& أهـ ـ ب . . rم. }
$$

דس. التيسير في القراءات السبع، لأبي عمرو عثمان بن سعيد الداني(ت § §ه)، عني بتصحيحه: أوتو برتزل، دار الكتب العربي،

$$
\text { بيروت، الطبعة الثالثة:7 • ـ اهـ } 910 \text { ام. }
$$

V r. جامع البيان في القراءات السبع، لأبي عمرو عثمان بن سعيد الداني(ت §؟ §ه)، تحقيق أربع رسائل علمية من جامعة أم القرى، 
رسالة دكتوراه ، وثلاث رسائل ماجستير ر

^ז. جمال القراء وكمال الإقراء، لعلم الدين علي بن محمد السخاوي (ت با Tهـ)، تحقيق:د/ علي حسين البواب، مكتبة الخانجي،

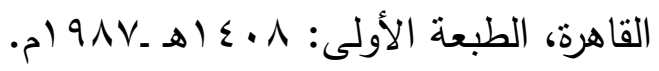
qس. حجة القراءات، لأبي زرعة عبد الرحمن بن زنجلة (ت في بداية ق عه)، تحقيق: د/ سعيد الأفغاني، مؤسسة الرسالة، بيروت،

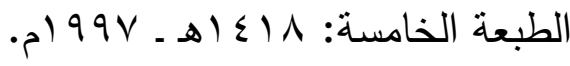
•ع. الحجة في القراءات السبع، لأبي عبد الله بن خالويه (ت • VIه)، تحقيق: د/ عبد العال سالم مكرم، دار الثروق، بيروت، الطبعة

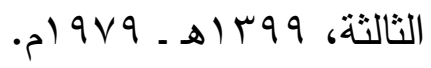
اء. الحجة للقراء السبعة، لأبي علي الحسن بن عبد الغفار الفارسي (ت المأمون للتراث، دمشق، الطبعة الأولى: ع • ـ اهـ ـ ع 9 (م. rـ. حرز الأماني ورجه التهاني(الثاطبية)، للقاسم بن فيرة الثاطبي(ت • 09هـ)، ضبط وتصحيح : محمد تميم الزعبي، مكتبة

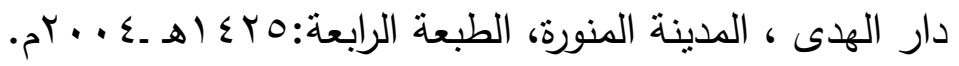
بـ. حق التلاوة، للشيخ حسيني شيخ عثمان، مكتبة المنار ، الأردن. §ء. الخصائص، لأبي الفتح بن جني(ت و \هـ)، تحقيق: محمد علي النجار، عالم الكتب، بيروت، الطبعة الثالثة: ب • ع إهـ 
0ـ. الدر المصون في علوم الكتاب المكنون، لأحمد بن يوسف السمين الحلبي(ت V07هـ)، تحقيق: د/ أحمد بن محمد الخراط، دار القلم،

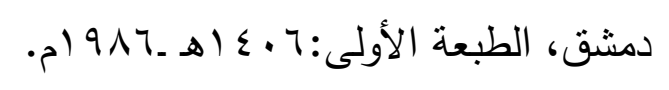

7ـ. الدرر الكامنة في أعيان المائة الثامنة، لثهاب الدين أبي الفضل أحمد بن حجر العسقلاني(ت AOr)، تحقيق: محمد سيد جاد الحق،

$$
\text { دار أم القرى، القاهرة. }
$$

عV محمد الجزري(تسبره)، ضبط وتصحيح: محمد تميم الزعبي، مكتبة دار الهدى، المدينة المنورة،الطبعة الثانية: ابـ اهـ ـ. . . بم.

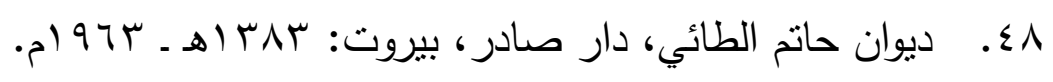
9ء. روح المعاني في تفسير القرآن العظيم والسبع المثاني، لأبي الفضل محمود الآلوسي (r) (ت . V r (هـ)، دار إحياء التراث العربي، بيروت. •. سر صناعة الإعراب، لأبي الفتح عثمان بن جني (ت بوم) ، تحقيق : د/ حسن هنداوي، دار القل ، دمشق، الطبعة

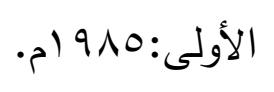

10. سنن أبي داود، لأبي داود سليمان بن الأشعث السجستاني

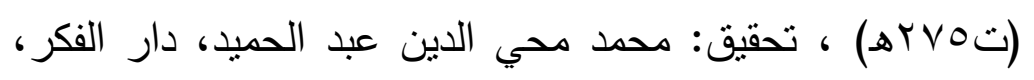

$$
\text { بيروت. }
$$

ror. سنن ابن ماجة، لأبي عبد الله محمد بن بزيد بن ماجة(ته بهـ)، تحقيق: محمد فؤاد عبد الباقي، دار الفكر، بيروت. 
ror. سنن الترمذي، لأبي عيسى محمد بن عيسى الترمذي(ت rV9ه)،

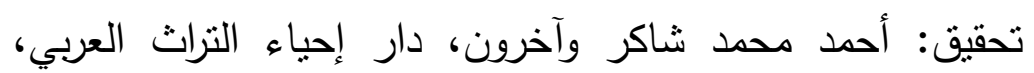

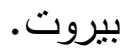

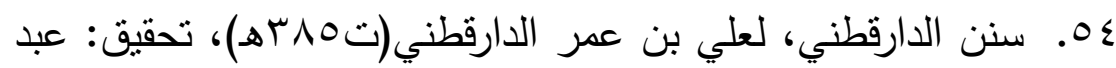

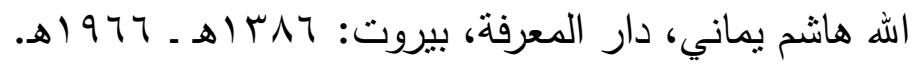
00. السنن الكبرى، لأحمد بن الحسين البيهقي(تم0^ـهـ)،تحقيق: محمد عبد القادر عطا، مكتبة دار الباز، مكة المكرمة: عاء (اهـ ـ . ) $99 \varepsilon$

7ه. سنن النسائي، لأحمد بن شعيب النسائي(ت · rهـ)، تحقيق: عبد الفتاح أبو غدة، مكتب المطبوعات الإسلامية، حلب، الطبعة الثانية: 7 • ع (اهـ ـ 917 (م. oV. سير أعلام النبلاء:، لشمس الدين محمد بن أحمد

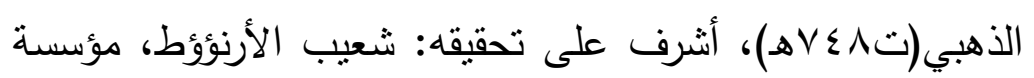

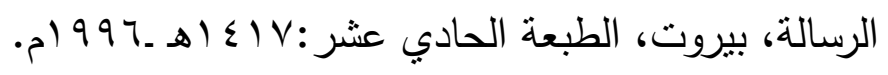
1ه. شرح طيبة النشر في القراءات العشر، لأبي القاسم محمد بن محمد النويري (ت (تمهـ)، تحقيق: جمال الدين شرف، دار الصحابة للتراث، طنطا، الطبعة الأولى:0 بـ اهـ ــ . . بم. ه. شرح الهداية، لأبي العباس أحمد بن عمار المهدوي(ت •عـهـ، تحقيق: د/ حازم سعيد حيدر، مكتبة الرشد، الرياض، الطبعة

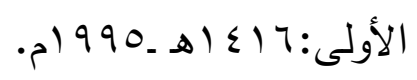


• 7. شعب الإيمان، لأحمد بن الحسين البيهقي(تم0^هـ)، تحقيق:

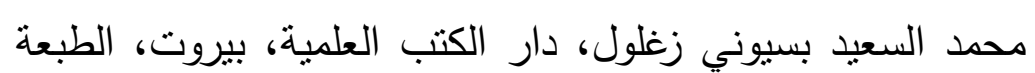

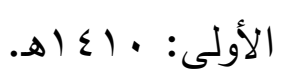

آ7. شيخ الجامع الأعظم محمد الطاهر بن عاشور حياته وآثناره، تأليف

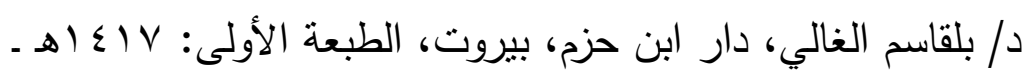
. $) 997$ ז7. الصحاح (تاج اللغة وصحاح العربية)، لإسماعيل بن أحمد الجوهري(ت أكه)، تحقيق أحمد عبد الغفور عطار، دار العلم للملايين، بيروت، الطبعة الثالثة:ء • ـ اهـ ــ19 ام. با. صحيح البخاري (الجامع الصحيح)، لمحمد بن إسماعيل

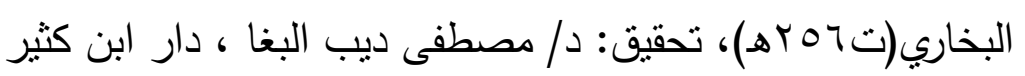

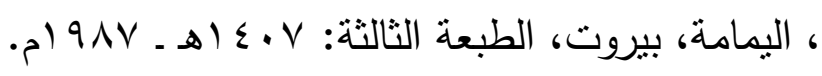
§. الحجاج القثيري النيسابوري(ت آجrهـ، تحقيق: محمد فؤاد عبد الباقي، دار إحياء التراث العربي، بيروت. 17. الطبقات الكبرى لمحمد بن سعد الزهري(ت. .r هـ)، دار صادر،

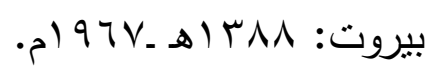
77. طبقات المفسرين، لجلال الدين عبد الرحمن السيوطي(ت ا(9ه)، تحقيق: علي محمد عمر ، مكتبة وهبة، القاهرة، الطبعة الأولى:

$$
\text { . ) } 9 \vee 7 \text {. ه }
$$


VT. طلائع البشر في توجيه القراءات العشر، لمحمد الصادق القماوي، مكتبة الإيمان، المنصورة، الطبعة الأولى

17. طيبة النشر في القراءات العشر، لمحمد بن محمد بن الجزري(ت سr/ه)، ضبط وتصحيح: محمد تميم الزعبي، مكتبة

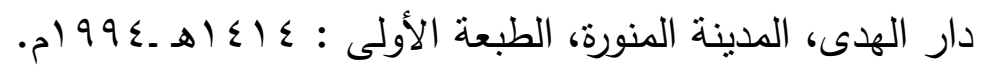

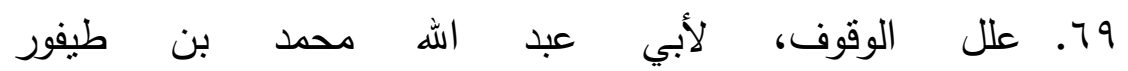
السجاوندي(ت. .07هـ)، تحقيق: د/ محمد بن عبد الله العيدي،

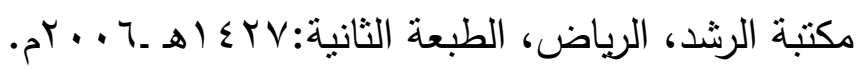
•V. غاية النهاية في طبقات القراء، لمحمد بن محمد بن محمد الجزري(ت سr/ه)، عني بنشره: جهبرجستراسر،مكتبة ابن تيمية،

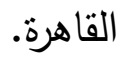
ا V. فتح القدير الجامع بين فني الرواية والدراية من علم التفسير، لمحمد بن علي الثوكاني (') (ت .0 ب اهـ)، دار المعرفة. r V. فتح الوصيد في شرح القصيد، لعلم الدين السخاوي (تش؟جه) تحقيق: جمال الدين شرف، دار الصحابة للتراث، طنطا، الطبعة

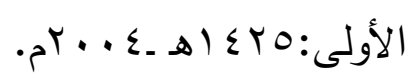

r V. فن الترتيل وعلومه، للشيخ أحمد بن أحمد بن محمد الطويل، صادر عن مجمع الملك فهذ لطباعة المصحف الثربف، الطبعة

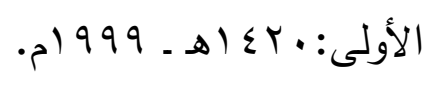


ع V. القاموس المحيط، لمجد الدين محمد بن يعقوب الفيروز

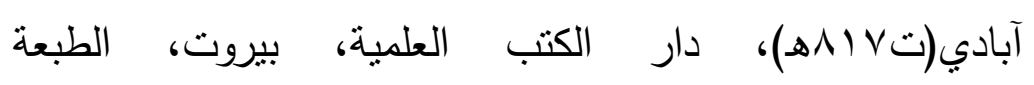

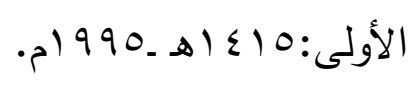

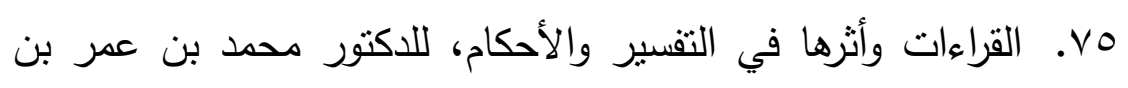

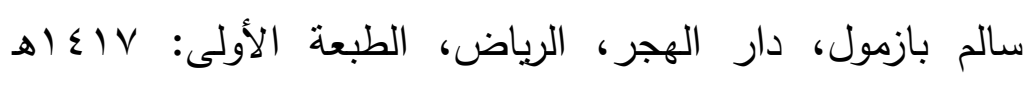

$$
\text { . } 1997 .
$$

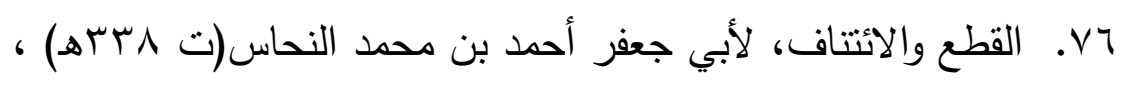

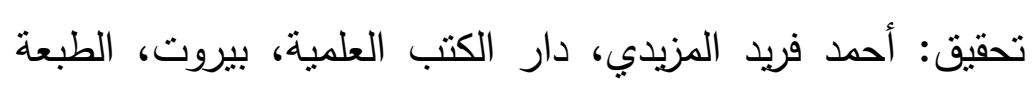

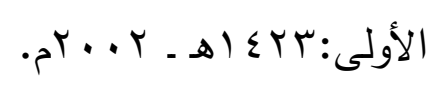

VV بسييويه(ت.11 (ه))، تحقيق: عبد السلام محمد هارون، مكتبة

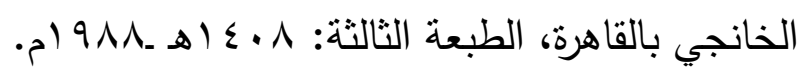

v1. كثاف اصطلاحات الفنون ، للثيخ محمد علي التهاوني ، تحقيق: د/ علي دحروج، مكتبة لبنان ناشرون، الطبعة الأولى: 997 ام. 9. الكثاف عن حقائق غوامض النتزيل وعيون الأقاويل في وجوه التأويل، لأبي القاسم الزمخشري (تم/ مهـ)، تحقيق: عادل أحمد

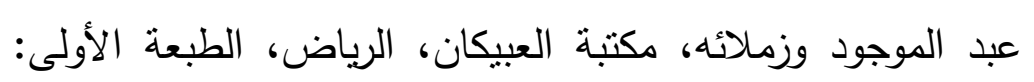

$$
.01991 \text { ـ ـ ـ (1) }
$$


•1. الكثف عن وجوه القراءات السبع وعللها وحججها، لمكي بن أبي طالب القيسي (تVY؟ه)، تحقيق: د/ محي الدين رمضان،

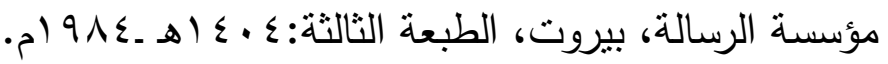
1 1. اللآلكئ الفريدة في شرح القصيدة(شرح الفاسي على الثاطبية)،لأبي عبد الله محمد بن الحسن الفاسي (ت707ه)، تحقيق: عبد الرزاق بن علي موسى، مكتبة الرشد، الرياض، الطبعة الأولى: جبـ اهـ ـ

$$
\cdot 0
$$

rA. لسان العرب، لجمال الدين أبي الفضل محمد بن مكرم بن منظور (ت ا (Vه)، دار صادر ، بيروت.

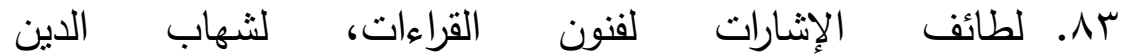
القسطلاني(ت بr هـ)، تحقيق: عامر سيد عثمان، وزميله، لجنة

$$
\text { إحياء التراث الإسلامي، القاهرة: بوس أهـ. }
$$

^ـ. مبادئ معرفة الوقوف، لمحمد بن عبد الحمبد البغدادي الثهير بـ (الحكيم زادة)(ت بعده • (هـ)، دراسة وتحقيق وشرح: الدكتور محمد بن إبراهيم المشهداني، مجلة كلية الدراسات الإسلامية والعربية ، مجلة علمية محكمة، العدد الرابع والثلاثون: ذو الحجة

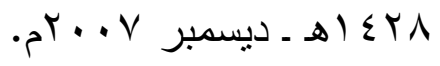

1.. مجاز القرآن، لأبي عبيدة معدر بن المنثى(ت . (Yه)، عارضه بأصوله وعلق عليه:د/ محمد فؤاد سزكين، مكتبة الخانجي بالقاهرة. 
41. المحتسب في تنبين وجوه شواذ القراءات والإيضاح عنها، لأبي القتح عثمان بن جني(ت بوr)، تحقيق: علي النجدي ناصف

وزملائه، لجنة إحباء كتب السنة، القاهرة: 10 (أهـ ــ99 ام.

AV

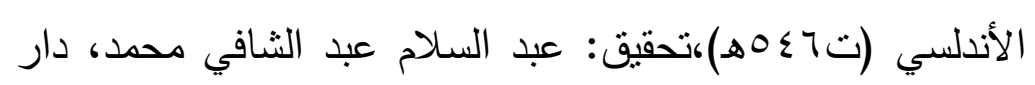

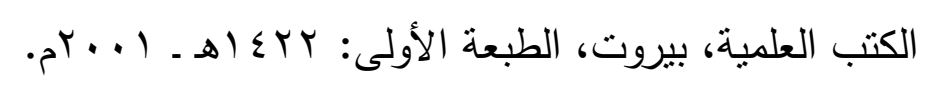

11. مختار الصحاح، لمحدد بن أبي بكر بن عبد القادر الرازي، تحقيق: محمود خاطر ، مكتبة لبنان ناشرون: 10 إ أهـ ـ 990 ام.

99. المرشد الوجيز إلى علوم تتعلق بالكتاب العزيز، لأبي شامة عبد

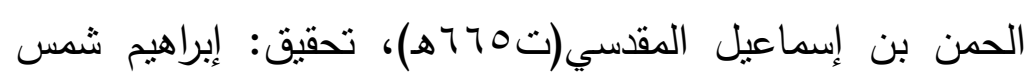

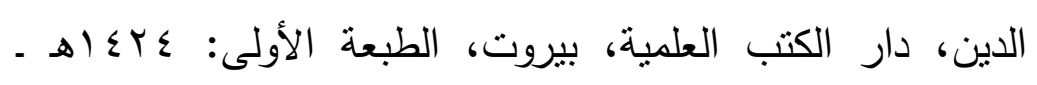

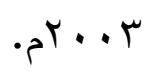

9. . المستدرك على الصحيحين، لأبي عبد الله محمد بن عبد الله الحاكم النيسابوري(ته •ــه)، تحقيق: مصطفى عبد القادر عطا، دار

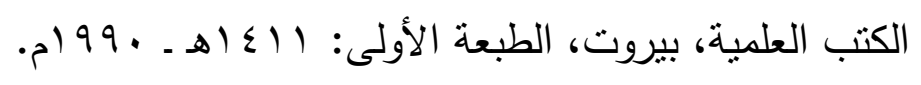

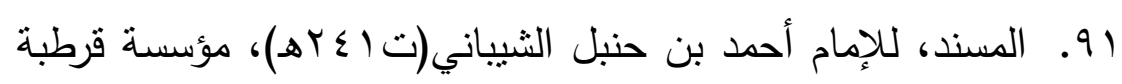
القاهرة. 
مواضع اختلاف الوقف والابتداء بـاختلاف قراءات القراء

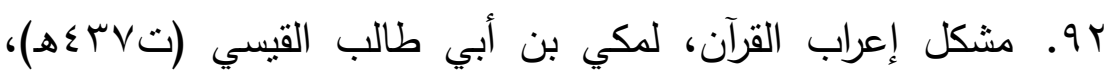
تحقيق:د/ حاتم صالح الضامن، مؤسسة الرسالة، بيروت، الطبعة

الثانية:0 . ـ الهـ ـ

ب9. المصباح المنير، لأحمد بن محمد بن علي الفيومي(ت حدود

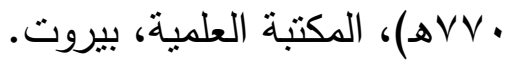

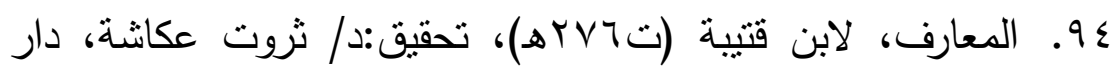
المعارف، مصر ، الطبعة الأولى:979 979

90 . معالم الاهتداء إلى معرفة الوقوف والابتداء، لمحمود بن خليل

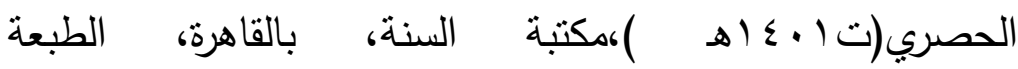

$$
\text { الأولى:rr| أهـ ـr . . .rم. }
$$

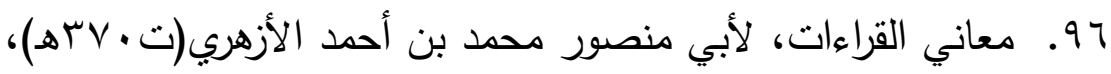
تحقيق: أحمد فريد المزيدي، دار الكتب العلمية، بيروت، الطبعة

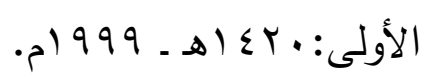

9V (ت 0 (1)هـ)، تحقيق: د/عبد الأمير محمد الورد، عالم الكتب،

بيروت، الطبعة الأولى:0. ـ ـ أهـ ـ 910 (م.

19. معاني القرآن، لأبي زكريا بحيى بن بزيد الفراء(ت • rهـ)، علم

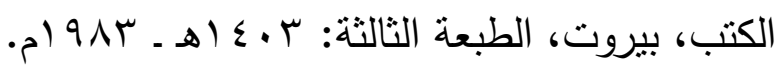

719 


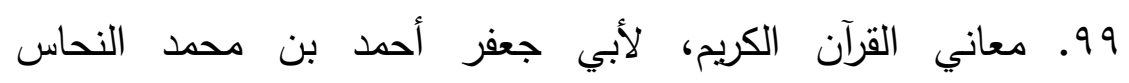

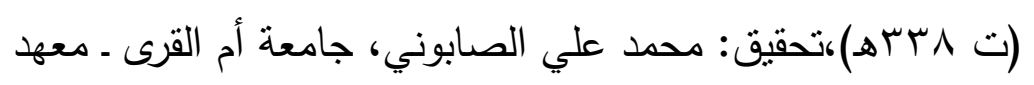

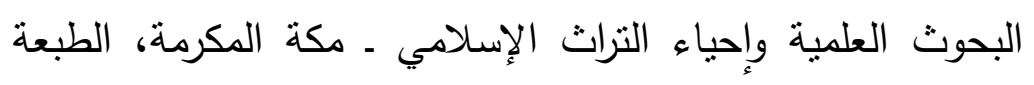

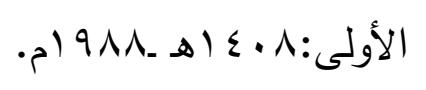

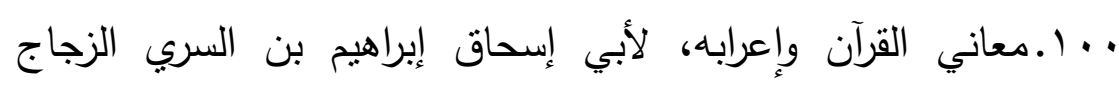

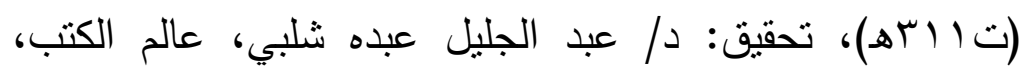

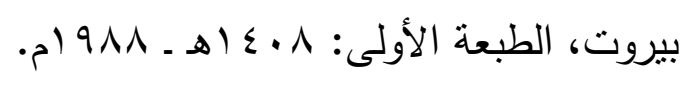

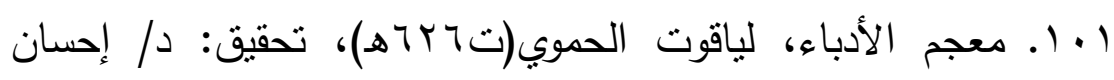

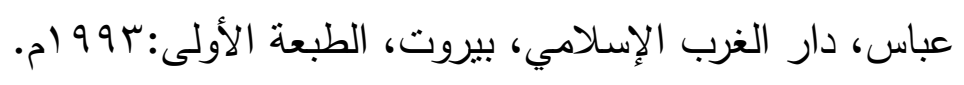

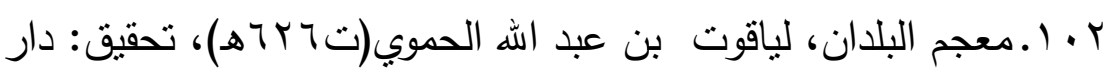
الفكر، بيروت.

r. (.معجم مقاييس اللغة، لأبي الحسين أحمد بن فارس(ت 90هـ)، تحقيق: عبد السلام محمد هارون، دار الفكر للطباعة والنشر:

$$
\text { . م) } 9 \vee 9 \text {. }
$$

ـ ـ ا.ـمعجم المؤلفين، لعمر رضا كحالة، دار إحياء التراث العربي. هـ ا. المعجم الموسوعي، لألفاظ القرآن الكريم وقراءاته، للاكتور أحمد

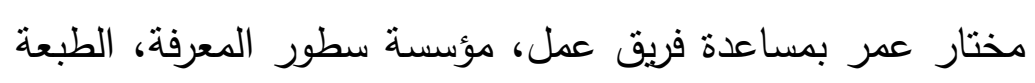

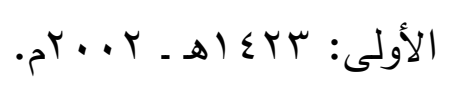


7 ـ (. معرفة القراء الكبار على الطبقات والأعصار ، لثمس الدين محمد بن أحمد الذهبي(تم乞 Vه)، أشرف على تحقيقه: بشار عواد معروف وزملائه، مؤسسة الرسالة، بيروت، الطبعة الأولى:

$$
\text { (ه. }
$$

V • ( ـ مغني اللبيب عن كتب الأعاريب ، لجمال الدين أبي محمد عبد الله بن يوسف بن هشام الأنصاري، تحقيق: د/ مازن المبارك ومحمد علي حمد الله، دار الفكر، بيروت، الطبعة السادسة: 910 ام. ^ • (. مقدمات في علم القراءات، للاكتور أحمد خالد شكري، وزملائه، دار

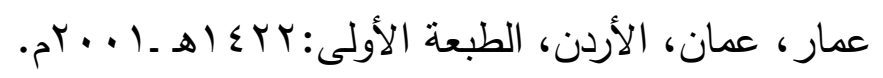
9. (ـ المقصد لتلخيص ما في المرشد في الوقف والابتداء، لأبي يحيى زكريا بن محمد الأنصاري (ت (7rوه)، دار المصحف، دمشق،

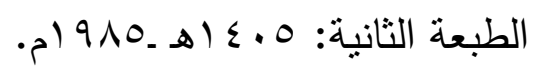

•11. المكتفى في الوقف والابتداء، لأبي عمرو عثمان بن سعيد الداني(ت §؟ §ه)، تحقيق: د/يوسف عبدالرحمن المرعشلي، مؤسسة الرسالة، بيروت، الطبعة الأولى: ع ـ ـ اهـ ـ ع 9 ام. 111 الكريم الأثموني (من علماء ق (اهـ)، تحقيق: عبدالرحيم

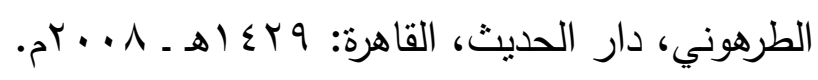

rا إ.مناهل العرفان في علوم القرآن، للثيخ عبد العظيم الزرقاني، 
تحقيق: فؤاد أحمد زمرلي، دار الكتاب العربي، بيروت، الطبعة

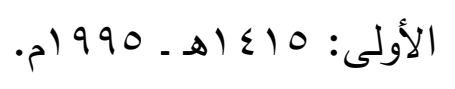

rا1/.منجد المقرئين ومرشد الطالبين، لمحمد بن محمد بن

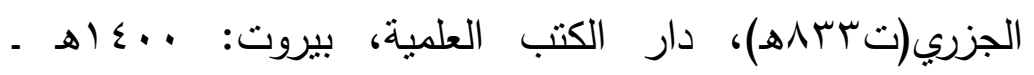
.0191 .

ـ (1 ا. الموضح في وجوه القراءات وعلاها، لنصر بن علي المعروف بابن أبي مريم(ت بعد:070هـ)تحقيق: د/ عمر حمدان الكبيسي، من مطبوعات الجماعة الخيرية لتحفيظ القرآن بجدة، الطبعة

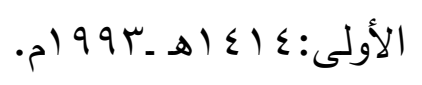

10 ا ـالنشر في القراءات العشر ، لمحمد بن محمد بن الجزري(ت بrمهـ)، تصحيح: علي محمد الضباع، دار الكنب العلمية، بيروت.

111.نهاية القول المفيد في علم التجويد، للثيخ محمد مكي نصر الجريسي، مراجعة: طه عبد الرؤوف سعد، مكتبة الصفا، القاهرة،

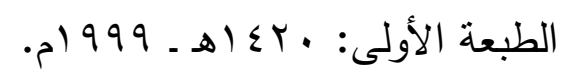

VII V الوافي بالوفيات، لصلاح الدين خليل بن أييك الصفدي، تحقيق:

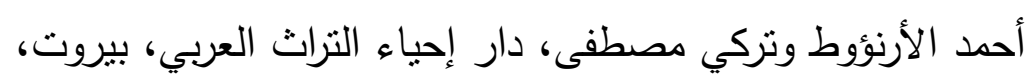

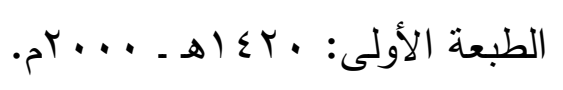


111.الوقف والابتداء في كتاب الله، لأبي القاسم يوسف بن علي

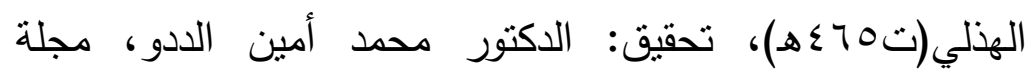
الثريعة والقانون، مجلة علمية محكمة، العدد الرابع والثلاثثون: ربيع

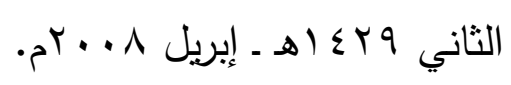


مجلة كلية الدراسات الإسلامية والعربية للبنات بكفر الشيخ العددالثاني -المجلد السادس لعام 1/.مم 